\title{
Amine Reactive Activated Esters of meso-CarboxyBODIPY: Fluorogenic Assays and Labeling of Amines, Amino Acids, and Proteins
}

$$
\begin{gathered}
\text { Sungjin Jeon, }{ }^{\dagger, \perp} \text { Tae-Il Kim, }{ }^{\dagger, \perp} \text { Hanyong Jin, }{ }^{\ddagger, \perp} \text { Uisung Lee, }^{\dagger} \text { Jeehyeon Bae, }^{\Delta} \\
\text { Jean Bouffard, }{ }^{\S, *} \text { and Youngmi Kim }{ }^{\dagger, *}
\end{gathered}
$$

${ }^{\dagger}$ Department of Chemistry and Research Institute of Basic Sciences, Kyung Hee University, 26 Kyungheedaero, Dongdaemun-gu, Seoul 02447, Korea

${ }^{\ddagger}$ Department of Life Science, Chung-Ang University, 84 Heukseok-ro, Dongjak-gu, Seoul 06974, Korea

${ }^{\Delta}$ School of Pharmacy, Chung-Ang University, 84 Heukseok-ro, Dongjak-gu, Seoul 06974, Korea

§Department of Chemistry and Nanoscience (BK 21 Plus), Ewha Womans University, 52 Ewhayeodae-gil,

Seodaemun-gu, Seoul, 03760, Korea

bouffard@ewha.ac.kr.Fax: +82-2-3277-3427

youngmi.kim@khu.ac.kr.Fax:+82 2-961-0443

\section{Table of Contents:}

1. Synthesis of Compounds $\quad$ S3

2. Photophysical Properties of Compounds $\quad$ S5

3. Sensing Response of 2-PFP toward Methylamine in $\mathrm{CH}_{3} \mathrm{CN} \quad \mathbf{S 1 0}$

4. Stability Studies of Compounds 2-PFP, 2-NHS and 3a-3c in $\mathrm{CH}_{3} \mathrm{CN} \quad \mathbf{S 1 6}$

5. Applications of 2-PFP as a Solid-State Indicator for Volatile Organic Amines $\mathbf{S 2 1}$

6. Reaction of 2-NHS with L-Lysine and Other L-Amino Acids in Aqueous Buffer $\mathbf{S 2 2}$

7. Stability Studies of 2-NHS and 3b in Aqueous Buffer Solution $\quad \mathbf{S 3 2}$

8. $\quad$ Fluorogenic Detection of Proteins on Electrophoresis Gels $\quad \mathbf{S 3 8}$

9. Quantitation of Proteins/Antibodies with 2-NHS in Aqueous Solution $\mathbf{S 4 3}$

10. Application of 2-NHS for the Intracellular Protein Labeling and its Fluorescence Microscope S51 Imaging

11. Application for Organelle-Specific Fluorescence Microscope Imaging $\quad$ S56

12. DFT Calculations $\quad$ S65

13. ${ }^{1} \mathrm{H}-\mathrm{NMR},{ }^{13} \mathrm{C}-\mathrm{NMR}$ and ${ }^{19} \mathrm{~F}-\mathrm{NMR}$ Spectra $\quad \mathbf{S 7 4}$

\begin{tabular}{ll} 
14. & References \\
\hline 883
\end{tabular} 


\section{Experimental}

\section{Materials}

All reagents were of the highest commercial quality and used as received without further purification. All solvents were spectral grade unless otherwise noted. Anhydrous tetrahydrofuran was obtained from Honeywell. Anhydrous dichloromethane, acetonitrile, toluene, ethanol, N,N-dimethylformamide (DMF), 4(dimethylamino)pyridine (DMAP), pentafluorophenol, piperidine, dimethylamine and reduced glutathione (GSH) were obtained from Alfa aesar. Tyramine, 1-ethyl-3-(3-dimethylaminopropyl)carbodiimide (EDC), and 1-hydroxybenzotriazole (HOBt) were purchased from TCI Co., Ltd.. $N$-Hydroxysuccinimide (NHS), methylamine (33 wt. \% in absolute ethanol), 1,3-diaminopropane, 1,4-diaminobutane, 1,5-diaminopentane, butylamine, hexylamine, isobutylamine, cyclohexylamine, benzylamine, histamine, diisopropylamine, trimethylamine (25 wt. \% in $\mathrm{H}_{2} \mathrm{O}$ ), triethylamine (TEA), polyethylene glycol dimethyl ether (PEGDME, average $\mathrm{M}_{\mathrm{n}} \sim 2,000$ ), lysozyme human (EC 3.2.1.17, 100,000 U/mg, $\mathrm{MW}=14.5 \mathrm{kDa}$ ), Immunoglobulin $\mathrm{G}$ from human serum (IgG, MW = $150 \mathrm{kDa}$ ), trypsin from porcine pancreas (EC 3.4.21.4, 1000-2000 U/mg), porcine liver esterase (PLE, EC 3.1.1.1, $17 \mathrm{U} / \mathrm{mg}$ ), lipases from porcine pancreas (PPL, EC 3.1.1.3, 100-500 U/mg), and bovine serum albumin (BSA, MW = 66.4 kDa) were purchased from Aldrich (Saint Louis, MO). Cathepsin B from human liver (EC 3.4.22.1, $10 \mathrm{U} / \mathrm{mg}$ ) was purchased from Calbiochem. Corp. (San Diego, CA). Flash column chromatography was performed using silica gel $(38-75 \mu \mathrm{m})$, which was supplied from Qingdao Meigao Chem. Co., Ltd (Chengyang, China). ERTraker ${ }^{\mathrm{TM}}$ Red, LysoTracker ${ }^{\circledR}$ Red DND-99 and MitoTracker ${ }^{\mathrm{TM}}$ Orange CMTMRos were purchased from Invitrogen (Carlsbad, USA). Pyridine and trifluoroacetic acid (TFA) were obtained from Samchun Co. (Korea). Aniline was obtained from JIN chemical \& pharmaceutical Co., Ltd.. Ammonia water was obtained from DSP GOKYO chemical company. $t$-Butylamine and ammonia (in methanol solution) were obtained from ACROS. Aqueous solutions were freshly prepared with deionized water from a water purification system (Younglin Corp. Korea). Compounds $\mathbf{1},{ }^{1} \mathbf{4},{ }^{2} \mathbf{5},{ }^{3}$ and $\mathbf{6}^{4}$ were prepared as described in the literature.

\section{General methods, instrumentation and measurements}

Synthetic manipulations that required an inert atmosphere (where noted) were carried out under nitrogen using standard Schlenk techniques. NMR $\left({ }^{1} \mathrm{H},{ }^{13} \mathrm{C}\right)$ spectra were recorded on Bruker Avance $400 \mathrm{MHz}$ spectrometer, and NMR $\left({ }^{19} \mathrm{~F}\right)$ spectrum was recorded on Varian $500 \mathrm{MHz}$ spectrometer. The ${ }^{1} \mathrm{H},{ }^{13} \mathrm{C}$ and ${ }^{19} \mathrm{~F}$ chemical shifts were reported as $\delta$ in units of parts per million (ppm), referenced to the residual solvent. Splitting patterns are denoted as s (singlet), d (doublet), t (triplet), q (quartet), m (multiplet), and br (broad). Matrix assisted laser desorption/ionization time-of-flight/time-of-flight (Ultraflextreme MALDI-TOF/TOF, Bruker) or high-resolution electrospray ionization (ESI) mass spectra were obtained at the Korean National Center for Inter-University Research. UV-Vis absorption spectra were obtained on a Scinco UV S-3100 spectrophotometer. Fluorescence measurements were recorded on a Hitachi F-7000 fluorescence spectrophotometer using quartz cuvettes with a path length of $1 \mathrm{~cm}$. Fluorescence quantum yields were determined by standard methods, using fluorescein $\left(\Phi_{\mathrm{F}}=0.95 \text { in } 0.1 \mathrm{~N} \mathrm{NaOH}\right)^{5}$ and rhodamine-6G $\left(\Phi_{\mathrm{FL}}=0.94\right.$ in EtOH). ${ }^{6}$ Particle size was measured by dynamic light scattering (DLS) using a Malvern particle analyzer ZEN1690. Scanning electron microscopy (SEM) images were obtained from a Carl Zeiss Sigma microscope operating at an accelerating voltage of $5.0 \mathrm{kV}$ (Oberkochen, Germany). SDS-PAGE analysis was performed using Powerpac ${ }^{\mathrm{TM}}$ Basic supply and Mini-PROTEAN Tetra Vertical Electrophoresis Cell (Bio-Rad). Ammonia gas was obtained from HVPE (Hydride Vapor Phase Epitaxy) system. 


\section{Synthesis of Compounds}

Synthesis of compounds 2-NHS, 2-PFP, and 3a-3c
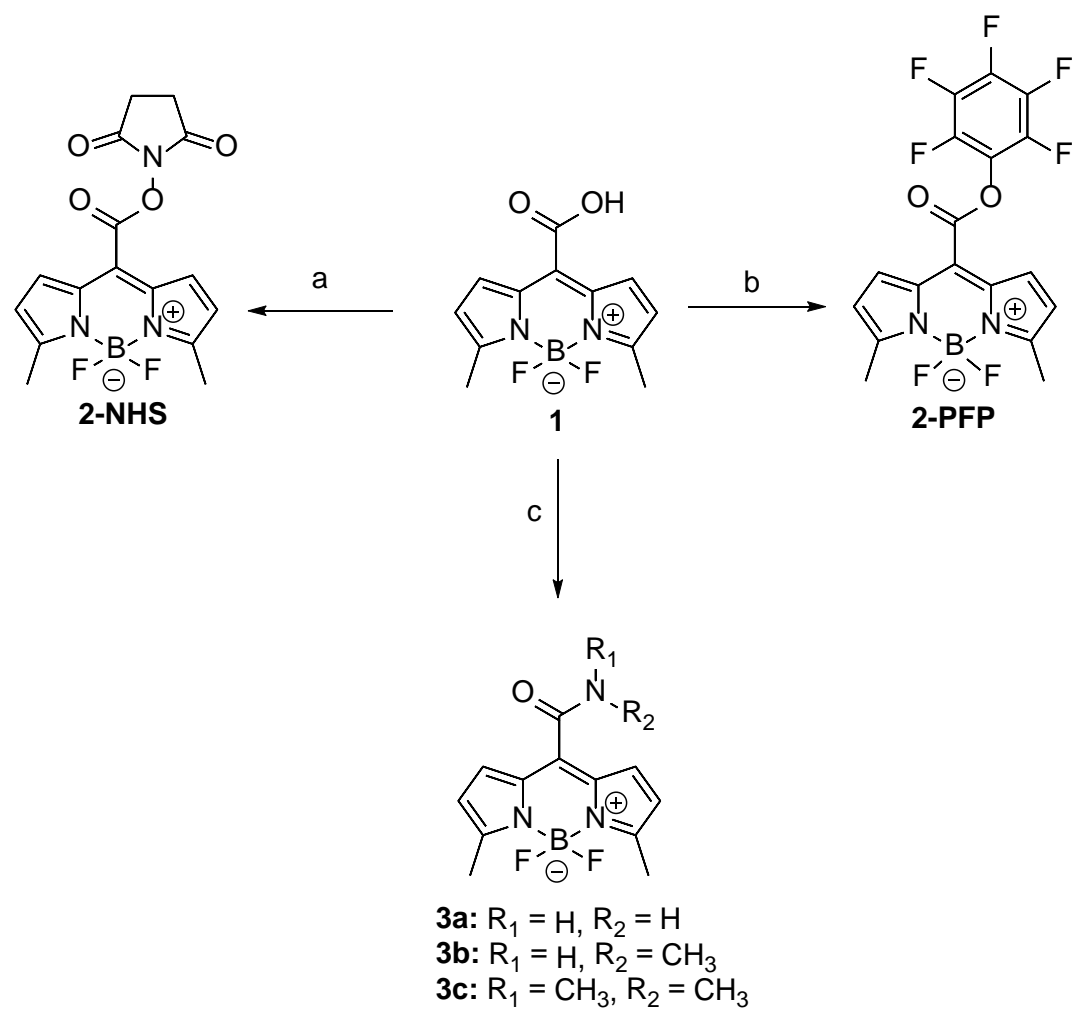

Scheme S1. Synthetic scheme for compounds 2-NHS, 2-PFP, and 3a-3c, reagents and conditions. (a) $\mathrm{N}$ hydroxysuccinimide (NHS), 1-ethyl-3-(3-dimethylaminopropyl)carbodiimide (EDC), dry $\mathrm{CH}_{2} \mathrm{Cl}_{2}, \mathrm{RT}, 2$ hours, 65\%. (b) 1-ethyl-3-(3-dimethylaminopropyl)carbodiimide (EDC), 1-hydroxybenzotriazole (HOBt), pentafluorophenol, 4-dimethylaminopyridine (DMAP), dry $\mathrm{CH}_{2} \mathrm{Cl}_{2}$ :DMF (9:1, v:v), RT, 2 h, 45\%. (c) 1-ethyl-3(3-dimethylaminopropyl)carbodiimide (EDC), 1-hydroxybenzotriazole (HOBt), $\mathrm{R}_{1} \mathrm{R}_{2} \mathrm{NH}$, dry $\mathrm{CH}_{2} \mathrm{Cl}_{2}$ : $\mathrm{DMF}$ (9:1, v:v), RT, 6 h, 34-92\%.

Compound 2-NHS. To a stirred solution of $\mathbf{1}^{1}(10 \mathrm{mg}, 0.038 \mathrm{mmol})$ in dry $\mathrm{CH}_{2} \mathrm{Cl}_{2}(2 \mathrm{~mL})$ at room temperature under a nitrogen atmosphere was added sequentially $N$-hydroxysuccinimide (NHS) ( $8.8 \mathrm{mg}, 0.076 \mathrm{mmol}$ ) and 1ethyl-3-(3-dimethylaminopropyl)carbodiimide (EDC) $(14.6 \mathrm{mg}, 0.076 \mathrm{mmol}$ ). After stirring at room temperature for 2 hours, the reaction solvent was removed under reduced pressure. The crude product was purified by column chromatography on silica gel using progressively more polar 20:1 to 3:1 hexanes:ethyl acetate as the mobile phase to afford 2-NHS as a khaki-black solid (9 mg, 65\%). ${ }^{1} \mathrm{H}-\mathrm{NMR}\left(400 \mathrm{MHz}, \mathrm{CDCl}_{3}\right): \delta=7.38$ (d, $\left.J=4.0 \mathrm{~Hz}, 2 \mathrm{H}\right)$, 6.36 (d, $J=4.0 \mathrm{~Hz}, 2 \mathrm{H}), 2.94$ (s, 4H), 2.65 (s, 6H). ${ }^{13} \mathrm{C}-\mathrm{NMR}$ (100 MHz, CDCl $): \delta=168.5,162.3,159.8,133.3$, 130.9, 121.6, 29.7, 25.7, 15.4. HR-MS (ESI): calcd. for $\mathrm{C}_{16} \mathrm{H}_{14} \mathrm{BF}_{2} \mathrm{~N}_{3} \mathrm{O}_{4}[\mathrm{M}+\mathrm{H}]^{+} 362.1124$, found 362.1125 .

Compound 2-PFP. To a stirred solution of $\mathbf{1}^{1}(70 \mathrm{mg}, 0.265 \mathrm{mmol})$ in dry $\mathrm{CH}_{2} \mathrm{Cl}_{2}: \mathrm{DMF}$ (9:1, v:v, $2 \mathrm{~mL}$ ) at room temperature under a nitrogen atmosphere was added sequentially 1-hydroxybenzotriazole (HOBt) (42 mg, 0.311 mmol) and 1-ethyl-3-(3-dimethylaminopropyl)carbodiimide (EDC) (76 mg, $0.398 \mathrm{mmol})$. After stirring at room temperature for $20 \mathrm{~min}$, pentafluorophenol (146 mg, $0.793 \mathrm{mmol})$ 4-dimethylaminopyridine (6 mg, $0.049 \mathrm{mmol})$ 
were added to the reaction mixture. After stirring at room temperature for 2 hours, the reaction solvent was removed under reduced pressure. The crude product was then purified by column chromatography on silica gel using progressively more polar 100:1 to 70:1 hexanes:ethyl acetate as the mobile phase to afford compound 2PFP as a khaki solid (51 mg, 45\%). ${ }^{1} \mathrm{H}$ NMR $\left(\mathrm{CDCl}_{3}, 400 \mathrm{MHz}\right): \delta=7.24$ (d, $\left.J=3.6 \mathrm{~Hz}, 2 \mathrm{H}\right), 6.32(\mathrm{~d}, J=4.0$ $\mathrm{Hz}, 2 \mathrm{H}), 2.60$ (s, 6H). ${ }^{13} \mathrm{C} \mathrm{NMR}\left(\mathrm{CDCl}_{3}, 100 \mathrm{MHz}\right): \delta=161.2,159.0,141.3,141.2,138.8,135.7,132.5,129.6$,

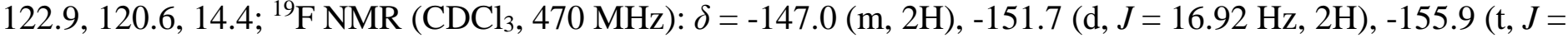
$21.62 \mathrm{~Hz}, 1 \mathrm{H}),-160.9$ (m, 2H). HR-MS (ESI): calcd. for $\mathrm{C}_{18} \mathrm{H}_{10} \mathrm{BF}_{7} \mathrm{~N}_{2} \mathrm{O}_{2}[\mathrm{M}-\mathrm{H}]^{+}$429.0645, found 429.0648.

Compound 3a. To a stirred solution of $\mathbf{1}^{1}(10 \mathrm{mg}, 0.038 \mathrm{mmol})$ in dry $\mathrm{CH}_{2} \mathrm{Cl}_{2}$ :DMF (9:1, v:v, $\left.2 \mathrm{~mL}\right)$ at room temperature under a nitrogen atmosphere was added sequentially 1-hydroxybenzotriazole (HOBt) (8.1 mg, 0.060 mmol) and 1-ethyl-3-(3-dimethylaminopropyl)carbodiimide (EDC) (11 mg, $0.058 \mathrm{mmol})$. After stirring at room temperature for $10 \mathrm{~min}$, ammonia in methanol solution $(0.380 \mathrm{mmol})$ was added to the reaction mixture. After stirring at room temperature for 3 hours, the reaction solvent was removed under reduced pressure. The crude product was then purified by column chromatography on silica gel using progressively more polar 10:1 to 1:1 hexanes:ethyl acetate as the mobile phase to afford compound 3a as a red solid (4 mg, 34\%). ${ }^{1} \mathrm{H}$ NMR (MeOD, $400 \mathrm{MHz}$ ): $\delta=7.15$ (d, $J=4.0 \mathrm{~Hz}, 2 \mathrm{H}), 6.40$ (d, $J=4.0 \mathrm{~Hz}, 2 \mathrm{H}), 2.57$ (s, 6H). ${ }^{13} \mathrm{C}$ NMR (MeOD, $\left.100 \mathrm{MHz}\right): \delta=$ 168.1, 160.9, 136.3, 133.4, 130.6, 121.2, 15.0. HR-MS (ESI): calcd. for $\mathrm{C}_{12} \mathrm{H}_{12} \mathrm{BF}_{2} \mathrm{~N}_{3} \mathrm{O}[\mathrm{M}+\mathrm{H}]^{+}$264.1120, found 264.1120 .

Compound 3b. To a stirred solution of $\mathbf{1}^{1}(10 \mathrm{mg}, 0.038 \mathrm{mmol})$ in dry $\mathrm{CH}_{2} \mathrm{Cl}_{2}: \mathrm{DMF}(9: 1, \mathrm{v}: \mathrm{v}, 2 \mathrm{~mL})$ at room temperature under a nitrogen atmosphere was added sequentially 1-hydroxybenzotriazole (HOBt) (13 mg, 0.095 mmol) and 1-ethyl-3-(3-dimethylaminopropyl)carbodiimide (EDC) (14.6 mg, $0.076 \mathrm{mmol}$ ). After stirring at room temperature for $10 \mathrm{~min}$, methylamine $(0.076 \mathrm{mmol})$ was added to the reaction mixture. After stirring at room temperature for 1 hour, the reaction solvent was removed under reduced pressure. The crude product was then purified by column chromatography on silica gel using progressively more polar 10:1 to 1:1 hexanes:ethyl acetate as the mobile phase to afford compound $\mathbf{3 b}$ as a red solid $(9.6 \mathrm{mg}, 92 \%)$. ${ }^{1} \mathrm{H}-\mathrm{NMR}\left(400 \mathrm{MHz}, \mathrm{CDCl}_{3}\right): \delta=7.07$ $(\mathrm{d}, J=3.6 \mathrm{~Hz}, 2 \mathrm{H}), 6.30$ (d, $J=4.0 \mathrm{~Hz}, 2 \mathrm{H}), 6.09$ (s, 1H), $3.03(\mathrm{~s}, 3 \mathrm{H}), 2.62(\mathrm{~s}, 6 \mathrm{H}) .{ }^{13} \mathrm{C}-\mathrm{NMR}\left(100 \mathrm{MHz} \mathrm{CDCl}_{3}\right)$ : $\delta=164.0,160.0,134.0,132.4,129.4,120.3,26.9,15.1$. HR-MS (ESI): calcd. for $\mathrm{C}_{13} \mathrm{H}_{14} \mathrm{BF}_{2} \mathrm{~N}_{3} \mathrm{O}[\mathrm{M}+\mathrm{H}]^{+}$ 278.1271, found 278.1276.

Compound 3c. To a stirred solution of $\mathbf{1}^{1}(10 \mathrm{mg}, 0.038 \mathrm{mmol})$ in dry $\mathrm{CH}_{2} \mathrm{Cl}_{2}: \mathrm{DMF}(9: 1, \mathrm{v}: \mathrm{v}, 2 \mathrm{~mL})$ at room temperature under a nitrogen atmosphere was added sequentially 1-hydroxybenzotriazole (HOBt) (13 mg, 0.095 mmol) and 1-ethyl-3-(3-dimethylaminopropyl)carbodiimide (EDC) (14.6 mg, $0.076 \mathrm{mmol})$. After stirring at room temperature for $10 \mathrm{~min}$, dimethylamine $(0.076 \mathrm{mmol})$ was added to the reaction mixture. After stirring at room temperature for 6 hours, the reaction solvent was removed under reduced pressure. The crude product was then purified by column chromatography on silica gel using progressively more polar 10:1 to 1:1 hexanes:ethyl acetate as the mobile phase to afford compound 3c as a red solid (10.2 mg, 92\%). ${ }^{1} \mathrm{H}-\mathrm{NMR}\left(400 \mathrm{MHz}, \mathrm{CDCl}_{3}\right): \delta=6.86$ (d, $J=4.0 \mathrm{~Hz}, 2 \mathrm{H}), 6.30$ (d, $J=4.4 \mathrm{~Hz}, 2 \mathrm{H}), 3.18$ (s, 3H), 2.99 (s, 3H), 2.62 (s, 6H). ${ }^{13} \mathrm{C}-\mathrm{NMR}\left(100 \mathrm{MHz} \mathrm{CDCl}_{3}\right)$ : $\delta=164.3,159.3,134.8,131.4,128.3,120.3,39.2$, 34.8, 15.0. HR-MS (ESI): calcd. For $\mathrm{C}_{14} \mathrm{H}_{16} \mathrm{BF}_{2} \mathrm{~N}_{3} \mathrm{O}[\mathrm{M}+\mathrm{H}]^{+}$, 292.1433, found.292.1434. 


\section{Photophysical Properties of Compounds}

Table S1. Photophysical properties of compounds 2-NHS and 2-PFP

\begin{tabular}{|c|c|c|c|c|c|}
\hline Compounds & Solvent & $\begin{array}{c}\lambda_{\text {abs. max }} \\
{[\mathrm{nm}]}\end{array}$ & $\begin{array}{c}\varepsilon^{b} \\
{\left[\mathrm{M}^{-1} \mathrm{~cm}^{-1}\right]}\end{array}$ & $\begin{array}{c}\lambda_{\text {em. max }}{ }^{c} \\
{[\mathrm{~nm}]}\end{array}$ & $\Phi_{\mathrm{FL}}^{d}$ \\
\hline 2-NHS & Toluene & 541 & 58000 & 626 & 0.41 \\
\hline 2-NHS & $\mathrm{CH}_{2} \mathrm{Cl}_{2}$ & 541 & 61000 & 621 & 0.43 \\
\hline 2-NHS & THF & 536 & 53000 & 614 & 0.47 \\
\hline 2-NHS & Acetone & 533 & 62000 & 613 & 0.45 \\
\hline 2-NHS & $\mathrm{EtOH}$ & 535 & 60000 & 615 & 0.41 \\
\hline 2-NHS & $\mathrm{CH}_{3} \mathrm{CN}$ & 534 & 56000 & 615 & 0.45 \\
\hline 2-NHS & DMSO & 541 & 45000 & 621 & 0.01 \\
\hline 2-NHS & Buffer $^{a}$ & 622 & 42000 & 648 & 0.001 \\
\hline 2-PFP & Toluene & 551 & 48000 & 628 & 0.46 \\
\hline 2-PFP & $\mathrm{CH}_{2} \mathrm{Cl}_{2}$ & 549 & 45000 & 621 & 0.36 \\
\hline 2-PFP & THF & 546 & 44000 & 619 & 0.33 \\
\hline 2-PFP & Acetone & 541 & 46000 & 615 & 0.45 \\
\hline 2-PFP & $\mathrm{EtOH}$ & 542 & 46000 & 615 & 0.33 \\
\hline 2-PFP & $\mathrm{CH}_{3} \mathrm{CN}$ & 541 & 42000 & 615 & 0.31 \\
\hline 2-PFP & DMSO & 546 & 42000 & 628 & 0.01 \\
\hline 2-PFP & Buffer $^{a}$ & $565(644)$ & 38000 & 618 & 0.001 \\
\hline
\end{tabular}

${ }^{a}$ PBS solution (10 mM, pH 7.4, 1\% $\left.\mathrm{CH}_{3} \mathrm{CN}\right) .{ }^{b}$ Measured at each absorption maximum. ${ }^{c}$ Excited at $470 \mathrm{~nm}$. ${ }^{d}$ Quantum yields vs. Rhodamine 6G in ethanol $\left(\Phi_{\mathrm{FL}}=0.94\right)^{6}$ for 2-NHS and 2-PFP. 
Table S2. Photophysical properties of compounds 3a-3c, and $\mathbf{1}$

\begin{tabular}{|c|c|c|c|c|c|}
\hline Compounds & Solvent & $\begin{array}{c}\lambda_{\text {abs. max }} \\
{[\mathrm{nm}]}\end{array}$ & $\begin{array}{c}\varepsilon^{b} \\
{\left[\mathrm{M}^{-1} \mathrm{~cm}^{-1}\right]}\end{array}$ & $\begin{array}{c}\lambda_{\text {em. max }}{ }^{c} \\
{[\mathrm{~nm}]}\end{array}$ & $\Phi_{\mathrm{FL}}^{d}$ \\
\hline $3 a$ & Toluene & 522 & 78000 & 569 & 0.73 \\
\hline $3 a$ & $\mathrm{CH}_{2} \mathrm{Cl}_{2}$ & 522 & 82000 & 566 & 0.78 \\
\hline 3a & $\mathrm{THF}$ & 515 & 79000 & 554 & 0.81 \\
\hline 3a & Acetone & 514 & 86000 & 552 & 0.82 \\
\hline 3a & $\mathrm{EtOH}$ & 516 & 82000 & 555 & 0.82 \\
\hline $3 a$ & $\mathrm{CH}_{3} \mathrm{CN}$ & 514 & 79000 & 551 & 0.80 \\
\hline 3a & DMSO & 517 & 82000 & 553 & 0.71 \\
\hline 3a & Buffer $^{a}$ & 519 & 77000 & 558 & 0.67 \\
\hline 3b & Toluene & 522 & 85000 & 559 & 0.74 \\
\hline $3 \mathbf{b}$ & $\mathrm{CH}_{2} \mathrm{Cl}_{2}$ & 521 & 88000 & 556 & 0.77 \\
\hline 3b & $\mathrm{THF}$ & 514 & 80000 & 547 & 0.81 \\
\hline $3 \mathbf{b}$ & Acetone & 517 & 89000 & 546 & 0.84 \\
\hline 3b & EtOH & 517 & 90000 & 546 & 0.79 \\
\hline 3b & $\mathrm{CH}_{3} \mathrm{CN}$ & 515 & 79000 & 546 & 0.85 \\
\hline $3 b$ & DMSO & 518 & 92000 & 546 & 0.82 \\
\hline $3 b$ & Buffer $^{a}$ & 519 & 78000 & 549 & 0.83 \\
\hline 3c & Toluene & 518 & 89000 & 544 & 0.81 \\
\hline $3 c$ & $\mathrm{CH}_{2} \mathrm{Cl}_{2}$ & 517 & 82000 & 541 & 0.85 \\
\hline $3 c$ & $\mathrm{THF}$ & 515 & 84000 & 537 & 0.94 \\
\hline $3 c$ & Acetone & 512 & 78000 & 536 & 0.94 \\
\hline $3 c$ & $\mathrm{EtOH}$ & 515 & 85000 & 538 & 0.93 \\
\hline $3 c$ & $\mathrm{CH}_{3} \mathrm{CN}$ & 512 & 82000 & 535 & 0.98 \\
\hline $3 c$ & DMSO & 517 & 85000 & 541 & 0.86 \\
\hline $3 c$ & Buffer $^{a}$ & 517 & 76000 & 540 & 0.97 \\
\hline 1 & Toluene & 515 & 33000 & 604 & 0.05 \\
\hline 1 & $\mathrm{CH}_{2} \mathrm{Cl}_{2}$ & 520 & 32000 & 600 & 0.09 \\
\hline 1 & $\mathrm{THF}$ & 531 & 42000 & 592 & 0.17 \\
\hline 1 & Acetone & 503 & 34000 & 590 & 0.09 \\
\hline 1 & $\mathrm{EtOH}$ & 501 & 60000 & 558 & 0.86 \\
\hline 1 & $\mathrm{CH}_{3} \mathrm{CN}$ & 492 & 35000 & 591 & 0.04 \\
\hline 1 & DMSO & 494 & 66000 & 551 & 0.002 \\
\hline 1 & Buffer $^{a}$ & 505 & 62000 & 554 & 0.78 \\
\hline
\end{tabular}

${ }^{a}$ PBS solution (10 mM, pH 7.4, 1\% $\left.\mathrm{CH}_{3} \mathrm{CN}\right) .{ }^{b}$ Measured at each absorption maximum. ${ }^{c}$ Excited at $470 \mathrm{~nm}$. ${ }^{d}$ Quantum yields vs. Fluorescein in $0.1 \mathrm{~N} \mathrm{NaOH}\left(\Phi_{\mathrm{FL}}=0.95\right)^{5}$ for $\mathbf{1}$ and 3a-3c. 

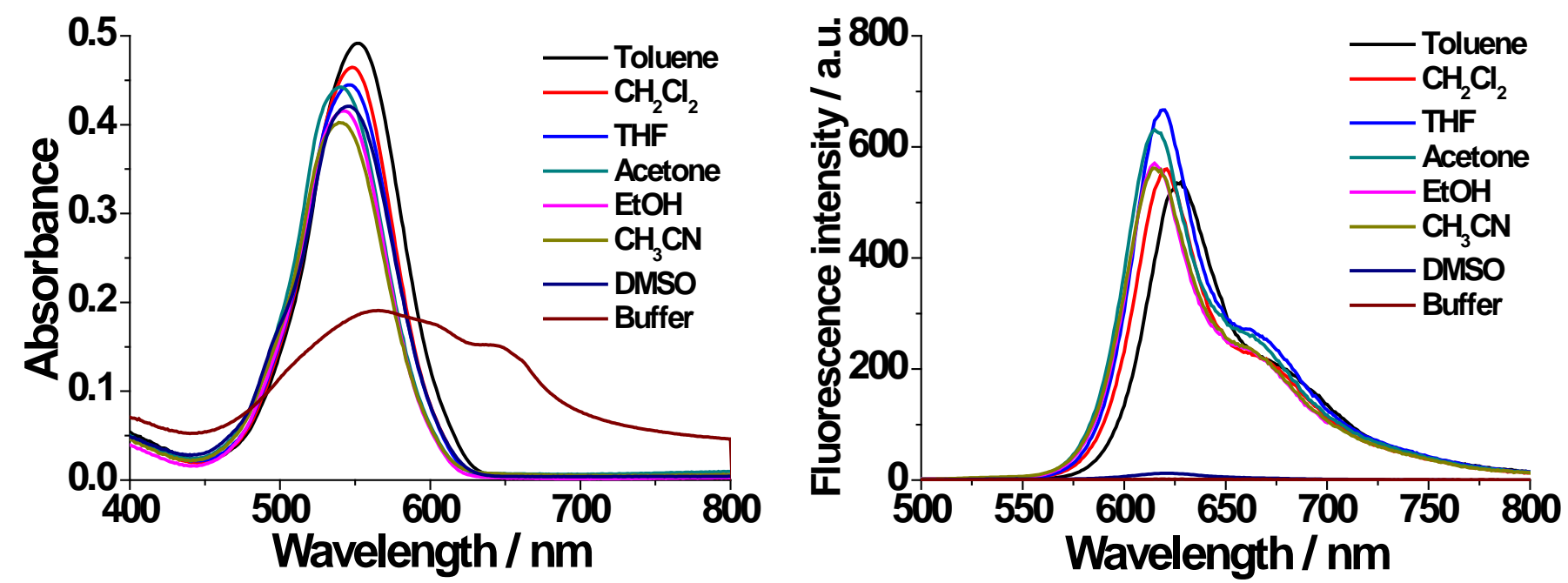

Figure S1. Absorption (left) and fluorescence emission (right) spectra of 2-PFP in various solvents at $25{ }^{\circ} \mathrm{C}$. Excited at $470 \mathrm{~nm}$. [2-PFP] $=10 \mu \mathrm{M}$. [2-PFP] $=5 \mu \mathrm{M}$ for PBS solution.
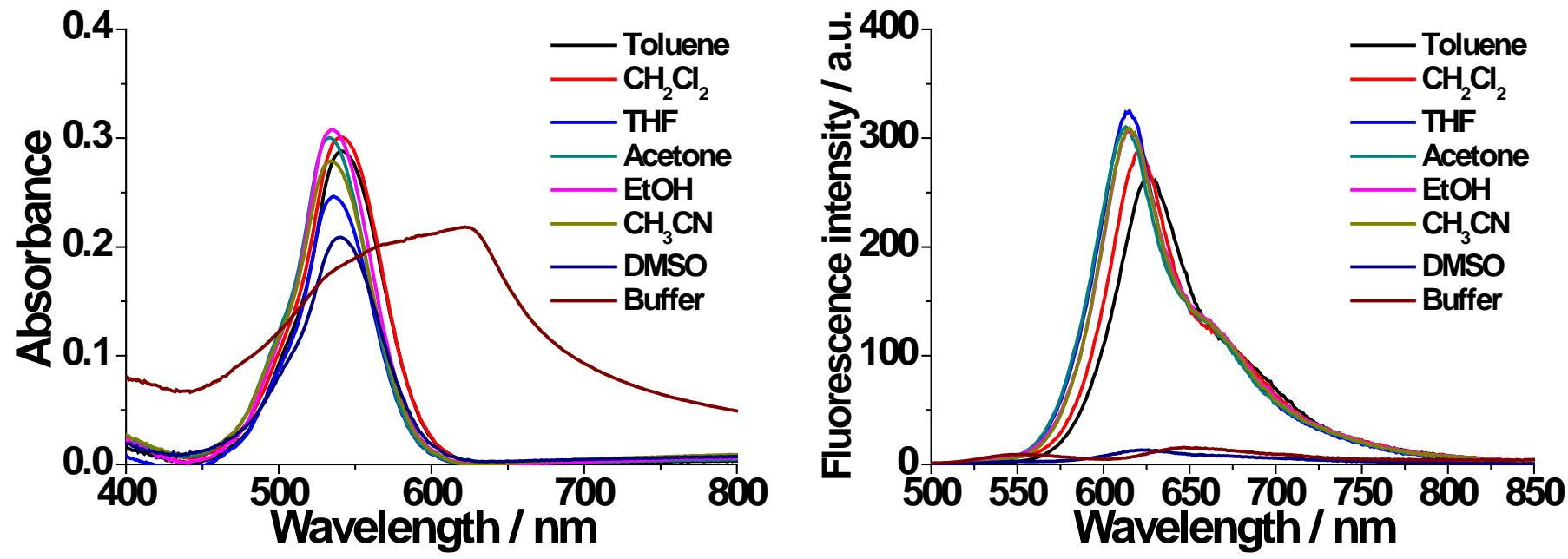

Figure S2. Absorption (left) and fluorescence emission (right) spectra of 2-NHS in various solvents at $25{ }^{\circ} \mathrm{C}$. Excited at $470 \mathrm{~nm}$. [2-NHS] $=5 \mu \mathrm{M}$. 

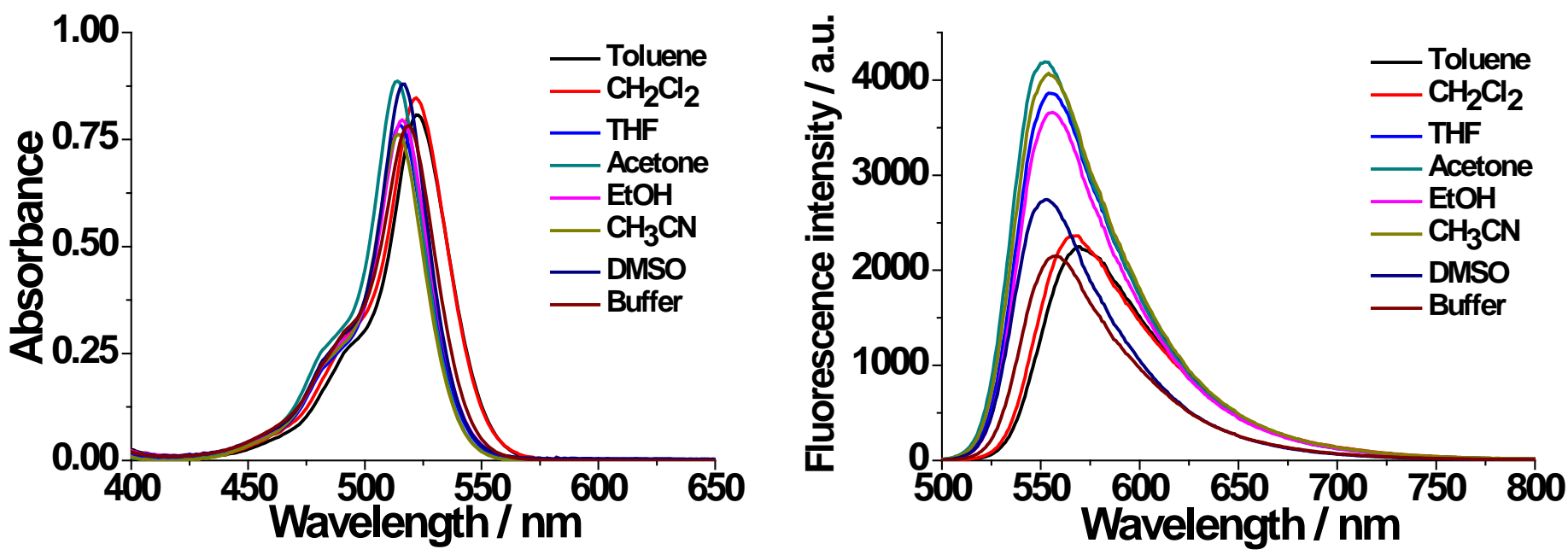

Figure S3. Absorption (left) and fluorescence emission (right) spectra of meso-amide BODIPY 3a in various solvents at $25^{\circ} \mathrm{C}$. Excited at $470 \mathrm{~nm}$. [3a] $=10 \mu \mathrm{M}$.
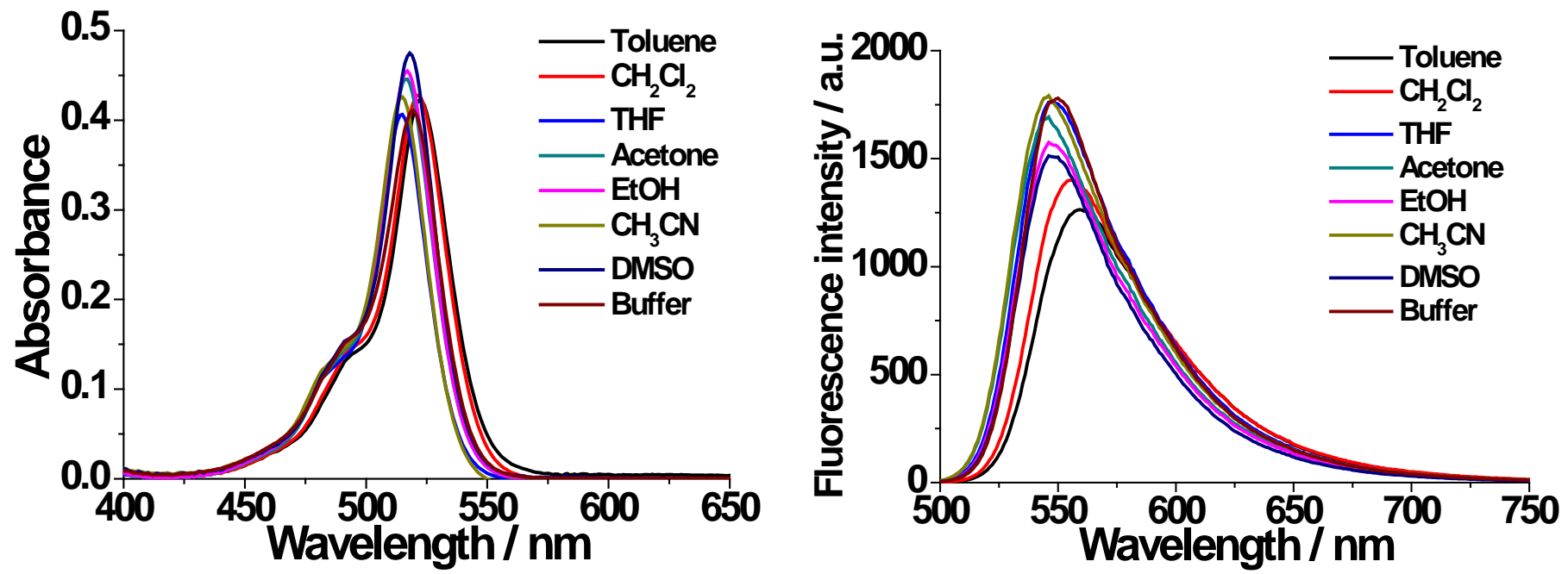

Figure S4. Absorption (left) and fluorescence emission (right) spectra of meso-amide BODIPY $3 \mathbf{b}$ in various solvents at $25^{\circ} \mathrm{C}$. Excited at $470 \mathrm{~nm}$. [3b] $=5 \mu \mathrm{M}$. 

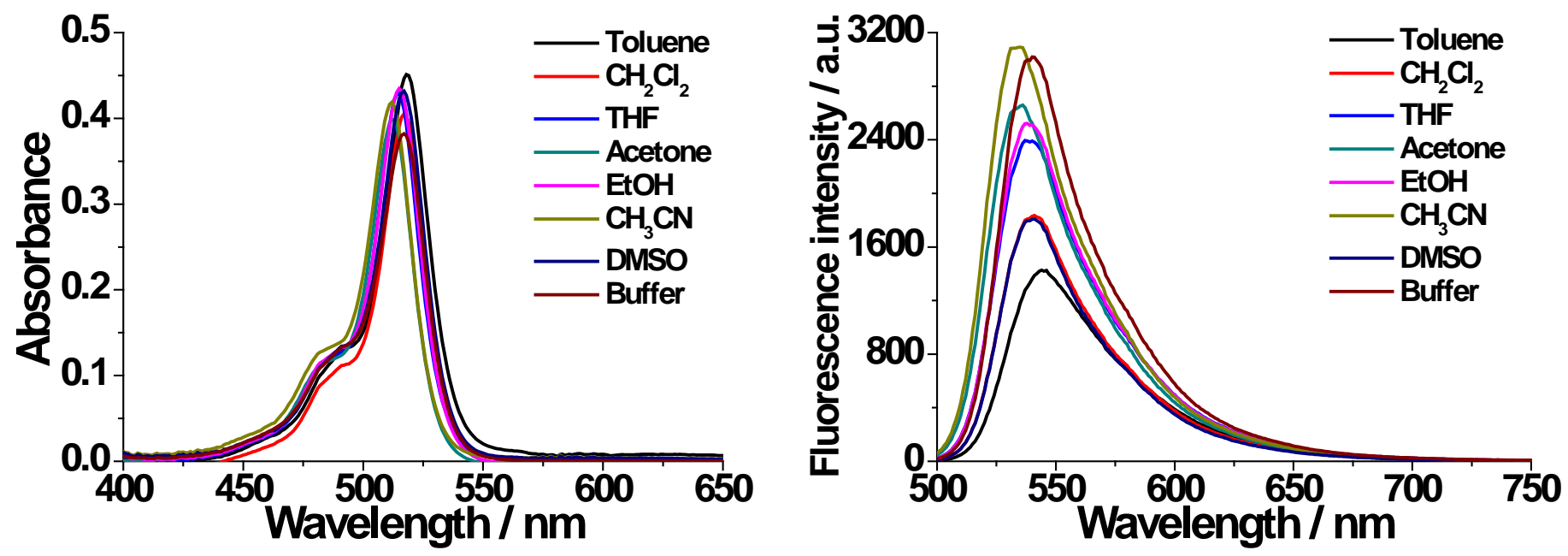

Figure S5. Absorption (left) and fluorescence emission (right) spectra of meso-amide BODIPY 3c in various solvents at $25{ }^{\circ} \mathrm{C}$. Excited at $470 \mathrm{~nm}$. [3c] $=5 \mu \mathrm{M}$.
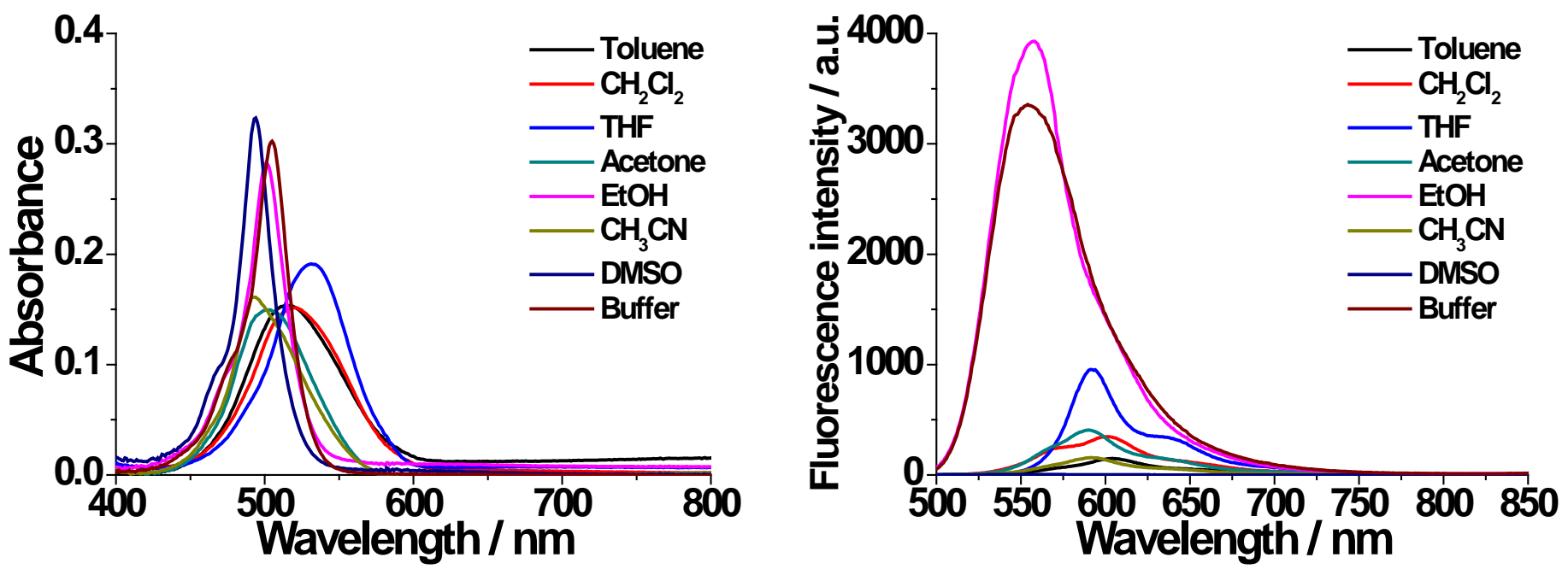

Figure S6. Absorption (left) and fluorescence emission (right) spectra of $\mathbf{1}$ in various solvents at $25{ }^{\circ} \mathrm{C}$. Excited at $470 \mathrm{~nm}$. [1] $=5 \mu \mathrm{M}$. 
(a) Absorption and fluorescence emission spectra of 2-PFP toward methylamine at different concentrations $(0-50 \mu M)$
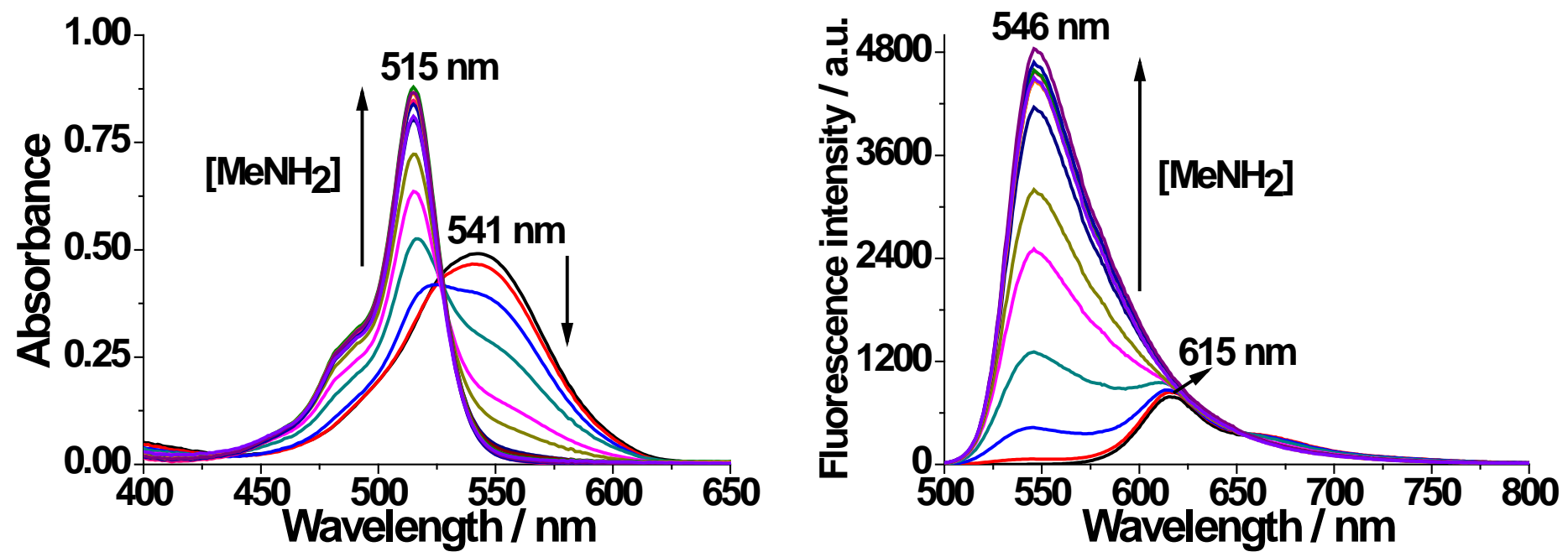

Figure S7. Absorption (left) and fluorescence emission (right) spectra of 2-PFP (10 $\mu \mathrm{M})$ upon addition of methylamine at different concentrations $(0,0.3,1.5,3,6,10,15,20,25,30,35,40,45,50 \mu \mathrm{M})$ in $\mathrm{CH}_{3} \mathrm{CN}$ at 25 ${ }^{\circ} \mathrm{C}$. Excited at $470 \mathrm{~nm}$. Incubation time $=5 \mathrm{~min}$.
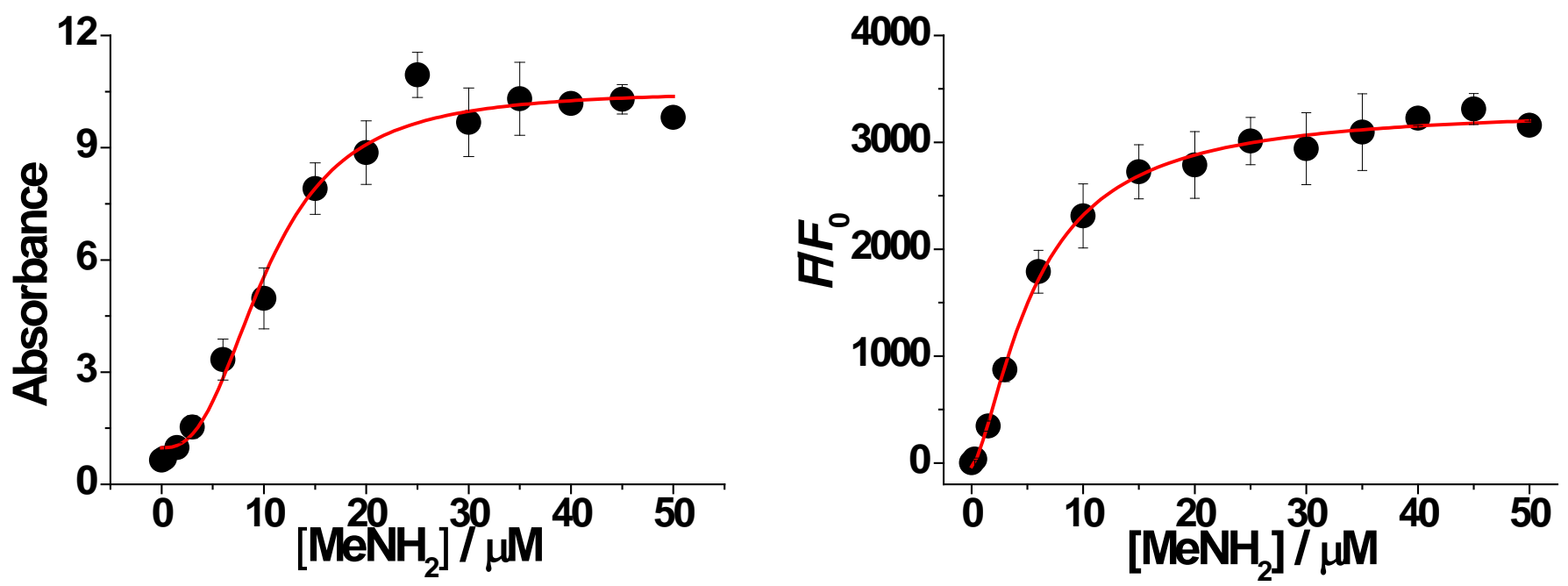

Figure S8. Absorbance ratio $\left(A_{515} / A_{541}\right.$, left $)$ and relative fluorescence intensity at $546 \mathrm{~nm}\left(F / F_{0}\right.$, right $)$ of 2-PFP $(10 \mu \mathrm{M})$ as a function of methylamine $(0-50 \mu \mathrm{M})$. Excited at $470 \mathrm{~nm}$. Incubation time $=5 \mathrm{~min}$. $F_{0}$ and $F$ correspond to the fluorescence intensity at $546 \mathrm{~nm}$ of 2-PFP in the absence and in the presence of methylamine, respectively. 
(a)

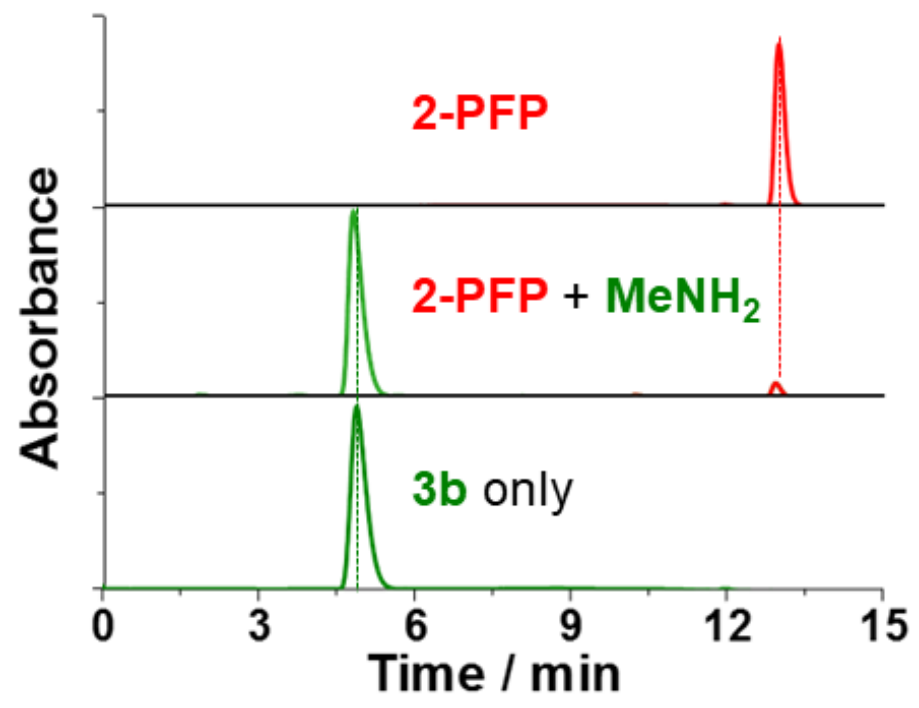

(b)

(c)
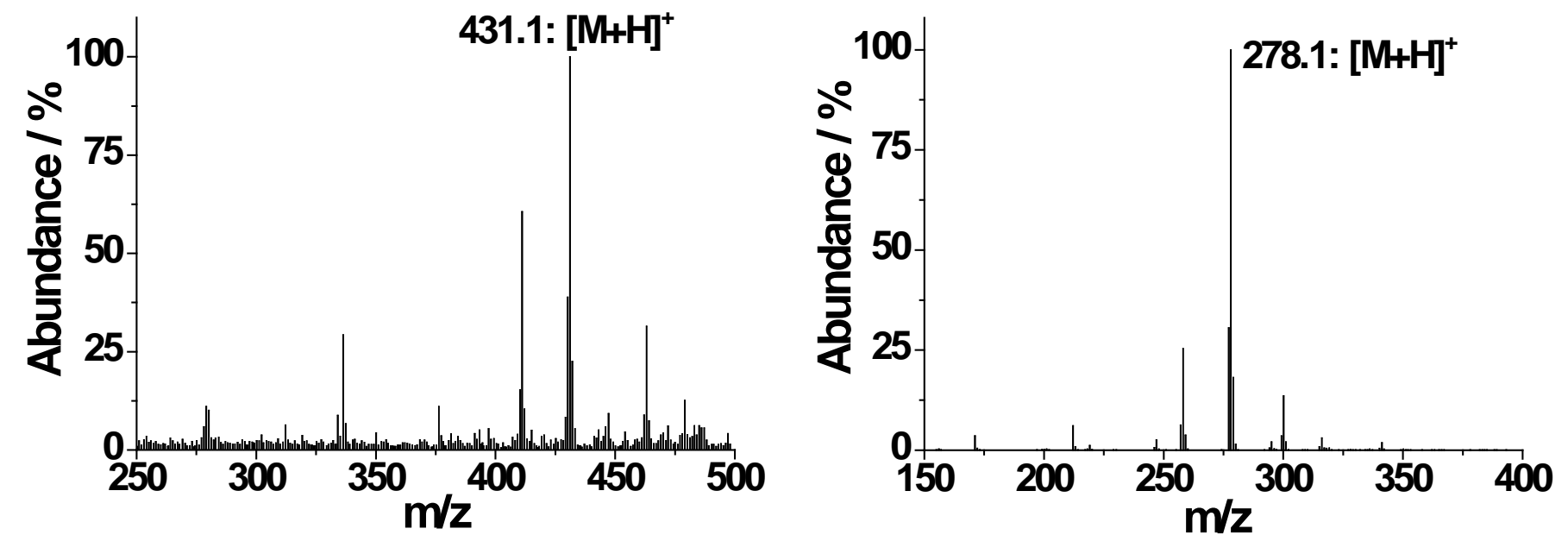

Figure S9. (a) HPLC chromatograms of 2-PFP only (top); 2-PFP 5 min after the addition of methylamine (1 equiv) at $25{ }^{\circ} \mathrm{C}$ (middle); 3b only (bottom). The samples were analyzed by LC-MS with a linear gradient elution (from 60 to $100 \% \mathrm{~B}$, A: deionized water, B: $\mathrm{CH}_{3} \mathrm{CN}$, flow rate $1 \mathrm{~mL} / \mathrm{min}$, UV: $530 \mathrm{~nm}$ ). ESI-MS spectra (positive mode) of the peak of retention time at (b) $13.19 \mathrm{~min}$ and (c) $4.89 \mathrm{~min}$. MW of the retention time at $13.19 \mathrm{~min}$ is 431.1, which corresponds to $[\mathrm{M}+\mathrm{H}]^{+}$for $\mathbf{2 - P F P}$ and $\mathrm{MW}$ of the retention time at $4.89 \mathrm{~min}$ is 278.1, which corresponds to $[\mathrm{M}+\mathrm{H}]^{+}$for $\mathbf{3 b}$. [2-PFP $]=[3 \mathbf{b}]=\left[\mathrm{MeNH}_{2}\right]=10 \mu \mathrm{M}$. 
<smiles></smiles>

2-PFP<smiles></smiles>

3b

(1) 2-PFP only
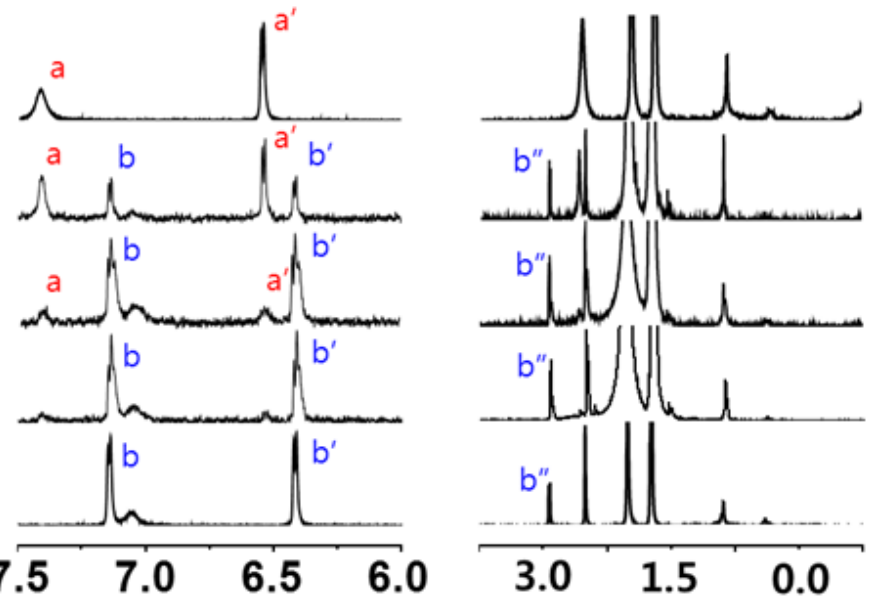

ppm / $\delta$

Figure S10. Partial ${ }^{1} \mathrm{H}-\mathrm{NMR}$ spectra of 2-PFP $(1 \mathrm{mM})$ in $\mathrm{CD}_{3} \mathrm{CN}$ before (1) and after the treatment with methylamine (2) 0.5 equiv (3) 1.0 equiv (4) 1.5 equiv. (5) ${ }^{1} \mathrm{H}-\mathrm{NMR}$ spectrum of $3 \mathbf{b}$ only. Incubation time $=5$ min. 

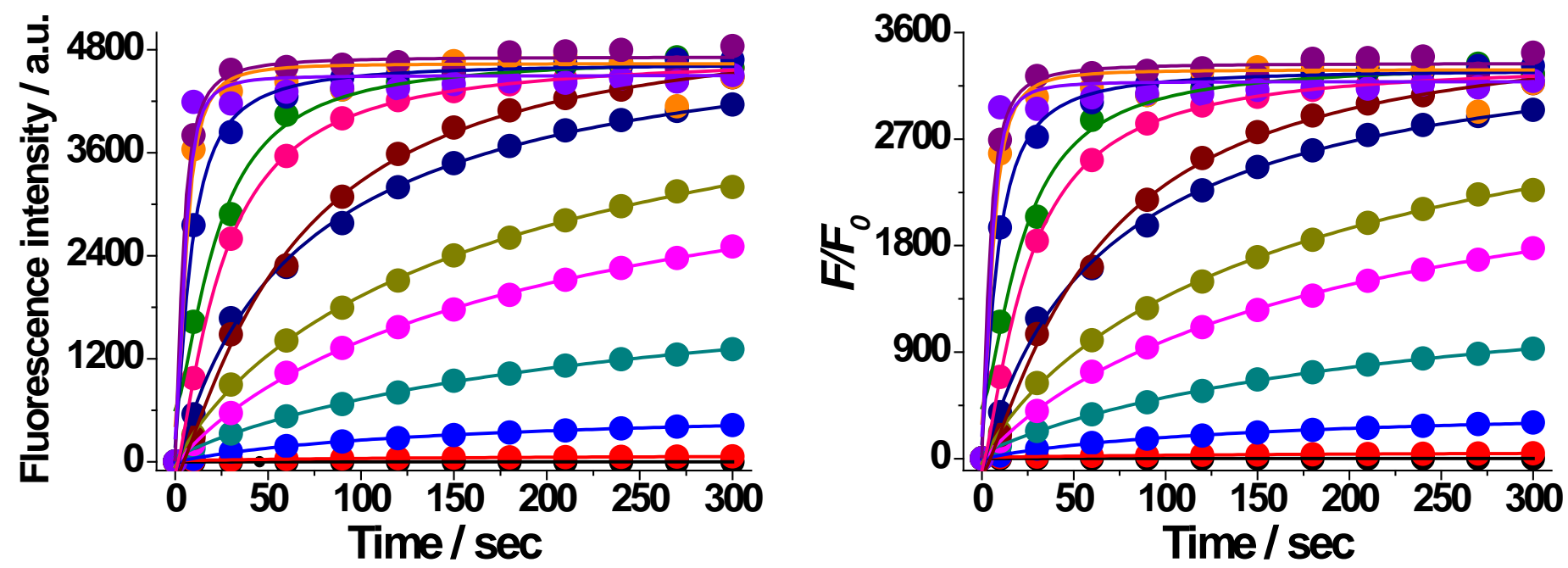

Figure S11. Time-dependent increase in fluorescence intensity at $546 \mathrm{~nm}$ of 2-PFP $(10 \mu \mathrm{M})$ upon addition of methylamine at different concentrations (bottom to top: $0,0.3,1.5,3,6,10,15,20,25,30,35,40,45,50 \mu \mathrm{M}$ ) in $\mathrm{CH}_{3} \mathrm{CN}$ at $25^{\circ} \mathrm{C}$. Excited at $470 \mathrm{~nm} . \mathrm{F}_{0}$ and $F$ correspond to the fluorescence intensity at $546 \mathrm{~nm}$ of 2-PFP in the absence and in the presence of methylamine, respectively. 
Under the pseudo first-order kinetics condition, kinetic rate constant $(k)$ was determined for the reaction between probe 2-PFP $(10 \mu \mathrm{M})$ and methylamine $(100 \mu \mathrm{M})$ in $\mathrm{CH}_{3} \mathrm{CN}$ at $25^{\circ} \mathrm{C}$, by monitoring the fluorescence intensity at $546 \mathrm{~nm}\left(\lambda_{\text {exc }}=470 \mathrm{~nm}\right)$, and fitting the fluorescence intensities to the pseudo first-order equation (1):

$$
\ln \left[\left(F_{\max }-F_{\mathrm{t}}\right) / \mathrm{F}_{\max }\right]=-k_{\mathrm{obs}} \cdot t
$$

where $F_{\mathrm{t}}$ is the fluorescence intensity at $546 \mathrm{~nm}$ at each time interval $(t)$ and $F_{\text {max }}$ is the maximum fluorescence intensity obtained after the reaction was completed. The observed rate constant $\left(k_{o b s}\right)$ was estimated from the slope of the pseudo first-order plot for the reaction of probe 2-PFP with methylamine, providing $k_{\mathrm{obs}}=0.0861 \mathrm{~s}^{-1}$. This corresponds to the second-order rate constant $(k)$ of $51,660 \mathrm{M}^{-1} \cdot \mathrm{min}^{-1}$.
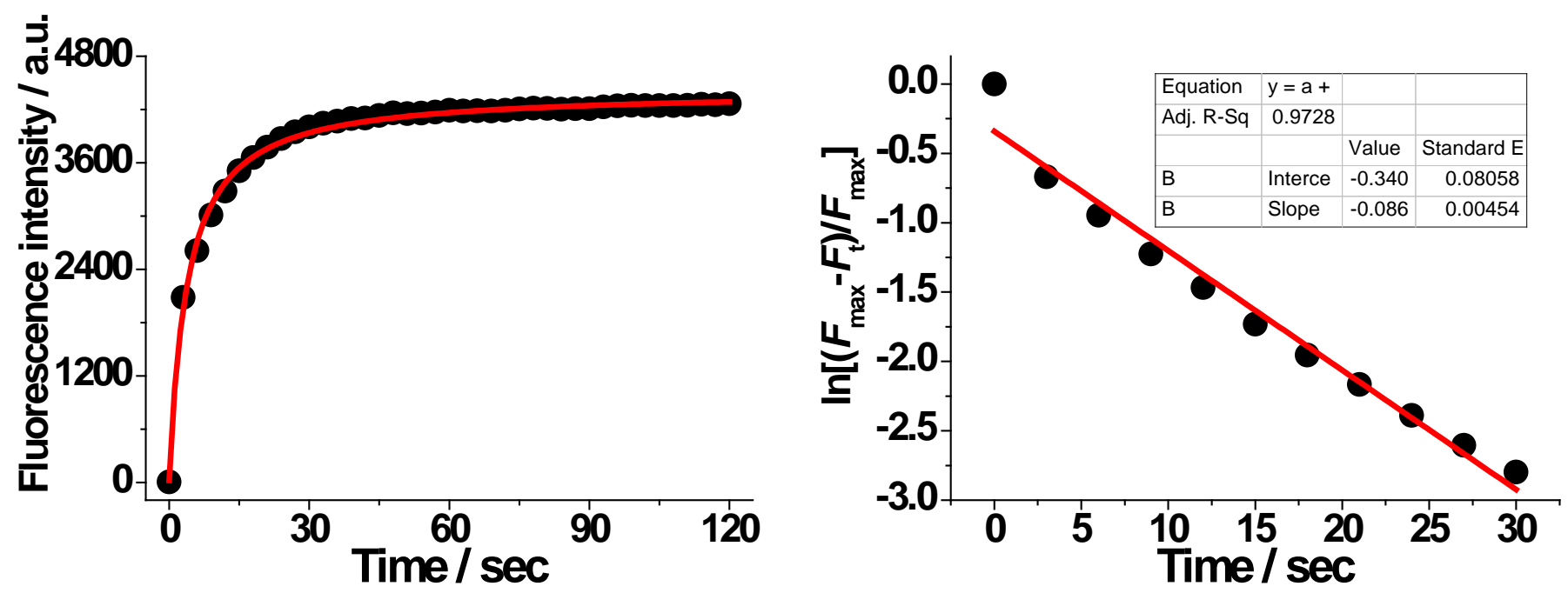

Figure S12. Pseudo first-order kinetic plot for the reaction of 2-PFP (10 $\mu \mathrm{M})$ with methylamine $(100 \mu \mathrm{M})$ in $\mathrm{CH}_{3} \mathrm{CN}$ at $25^{\circ} \mathrm{C}$. The fluorescence intensity at $546 \mathrm{~nm}$ was recorded every $3 \mathrm{sec}(0-120 \mathrm{sec})$. Excited at $470 \mathrm{~nm}$.

\section{(f) Determination of LOD (limit of detection) for methylamine using 2-PFP}

The fluorescence emission spectra of 2-PFP in $\mathrm{CH}_{3} \mathrm{CN}$ were collected for 25 times to determine the background noise $\sigma$. Fluorescence turn-on response of 2-PFP was monitored $5 \mathrm{~min}$ after the addition of methylamine at different concentrations. A linear regression curve was then fitted $\left(R^{2}=0.9792\right)$ according to relative fluorescence intensity at $546 \mathrm{~nm}$ as a function of an amount of methylamine $(0-6 \mu \mathrm{M})$, and the slope of the curve was obtained. Detection limit $(3 \sigma /$ slope $)$ was determined to be $6.9 \mathrm{nM}(0.214 \mu \mathrm{g} / \mathrm{L})$ for methylamine. 


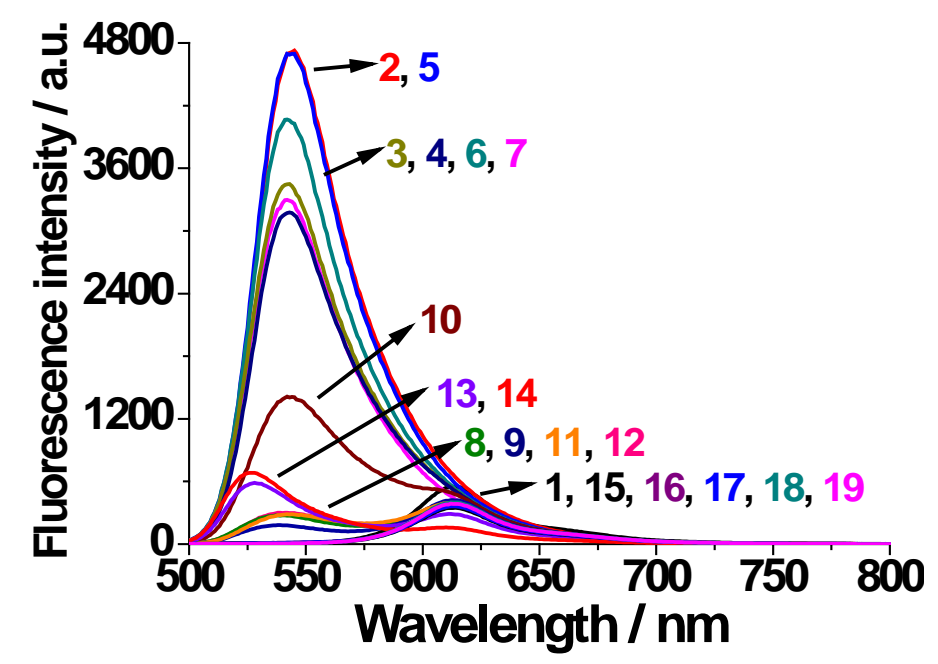

Figure S13. Fluorescence emission spectra of 2-PFP upon addition of various analytes in $\mathrm{CH}_{3} \mathrm{CN}$ at $25^{\circ} \mathrm{C}$. (1) 2-PFP only as a control, (2) methylamine, (3) 1-butanamine, (4) 1-hexanamine, (5) 1,3-diaminopropane, (6) 1,4diaminobutane, (7) 1,5-diaminopentane, (8) isobutylamine, (9) cyclohexylamine, (10) histamine, (11) benzylamine (12) tyramine, (13) dimethylamine, (14) piperidine, (15) diisopropylamine, (16) $t$-butylamine, (17) trimethylamine, (18) pyridine, (19) aniline. Excited at $470 \mathrm{~nm}$. [2-PFP] $=10 \mu \mathrm{M}$. [Analyte] = $20 \mu \mathrm{M}$. Incubation time $=5 \mathrm{~min}$. 


\section{Stability Studies of Compounds 2-PFP, 2-NHS and 3a-3c in $\mathrm{CH}_{3} \mathrm{CN}$}

To examine the chemical stabilities of 2-PFP, 2-NHS, and 3a-3c in $\mathrm{CH}_{3} \mathrm{CN}$, we monitored the absorption and fluorescence emission spectra of 2-PFP, 2-NHS, and 3a-3c every 1 hour ( $>6$ hours) at $25{ }^{\circ} \mathrm{C}$. As shown in Figures S14-18, negligible changes in absorption and fluorescence emission spectra were observed, indicating that 2-PFP, 2-NHS, and 3a-3c are highly stable in $\mathrm{CH}_{3} \mathrm{CN}$.

We also investigated the photostabilities of 2-PFP, 2-NHS and 3a-3c in $\mathrm{CH}_{3} \mathrm{CN}$ at $25^{\circ} \mathrm{C}$ (Figures S19-20). The photooxidation studies were performed by continuous irradiation of each solution using a $150 \mathrm{~W}$ steady-state Xe lamp as the irradiation source under aerobic conditions. The photoinduced degradations were quantified by monitoring the decrease of fluorescence intensity of 2-PFP, 2-NHS and 3a-3c, respectively, as a function of elapsed photolysis time.

(a) Chemical stability of meso-ester BODIPYs 2-PFP and 2-NHS in $\mathrm{CH}_{3} \mathrm{CN}$
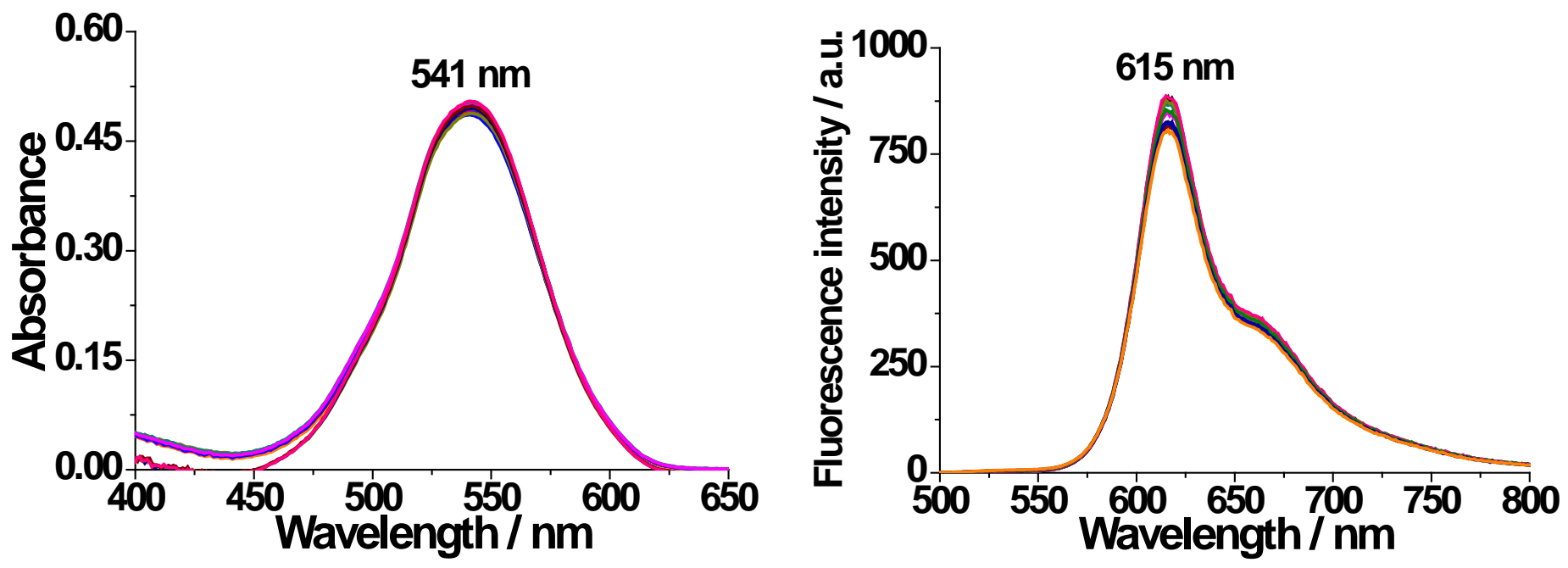

Figure S14. Time-dependent absorption (left) and fluorescence emission (right) spectra of 2-PFP in $\mathrm{CH}_{3} \mathrm{CN}$ at $25^{\circ} \mathrm{C}$. The spectra were obtained every 1 hour (0-12 hours). [2-PFP] $=10 \mu \mathrm{M}$. Excited at $470 \mathrm{~nm}$. 

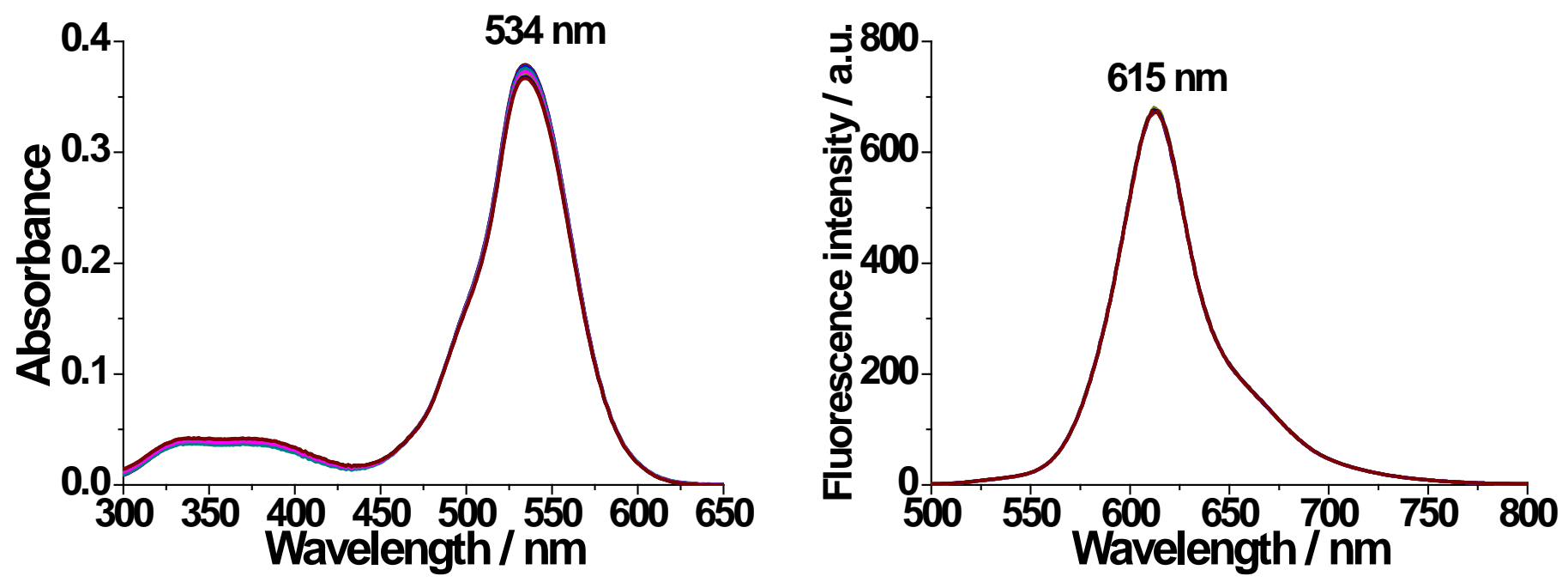

Figure S15. Time-dependent absorption (left) and fluorescence emission (right) spectra of 2-NHS (5 $\mu \mathrm{M})$ in $\mathrm{CH}_{3} \mathrm{CN}$ at $25^{\circ} \mathrm{C}$. The spectra were obtained every 1 hour (0-6 hours). Excited at $470 \mathrm{~nm}$. 

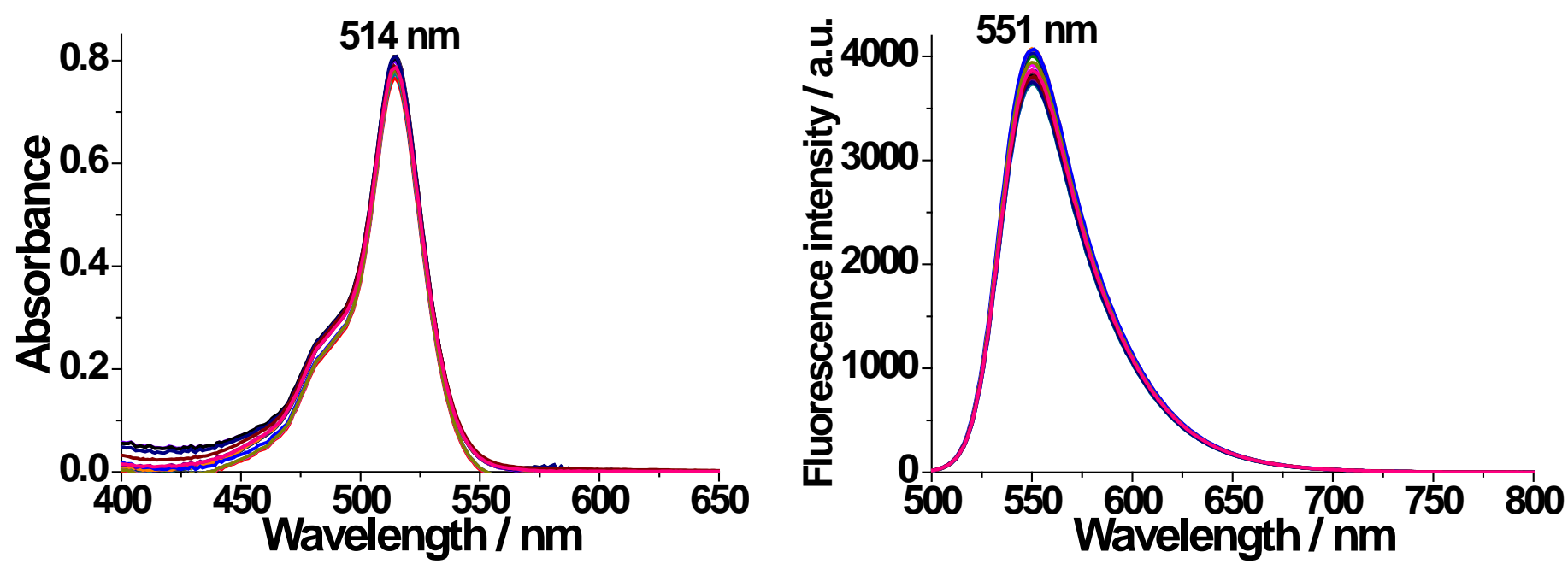

Figure S16. Time-dependent absorption (left) and fluorescence emission (right) spectra of $3 a$ in $\mathrm{CH}_{3} \mathrm{CN}$ at $25{ }^{\circ} \mathrm{C}$. The spectra were obtained every 1 hour (0-12 hours). [3a] $=10 \mu \mathrm{M}$. Excited at $470 \mathrm{~nm}$.
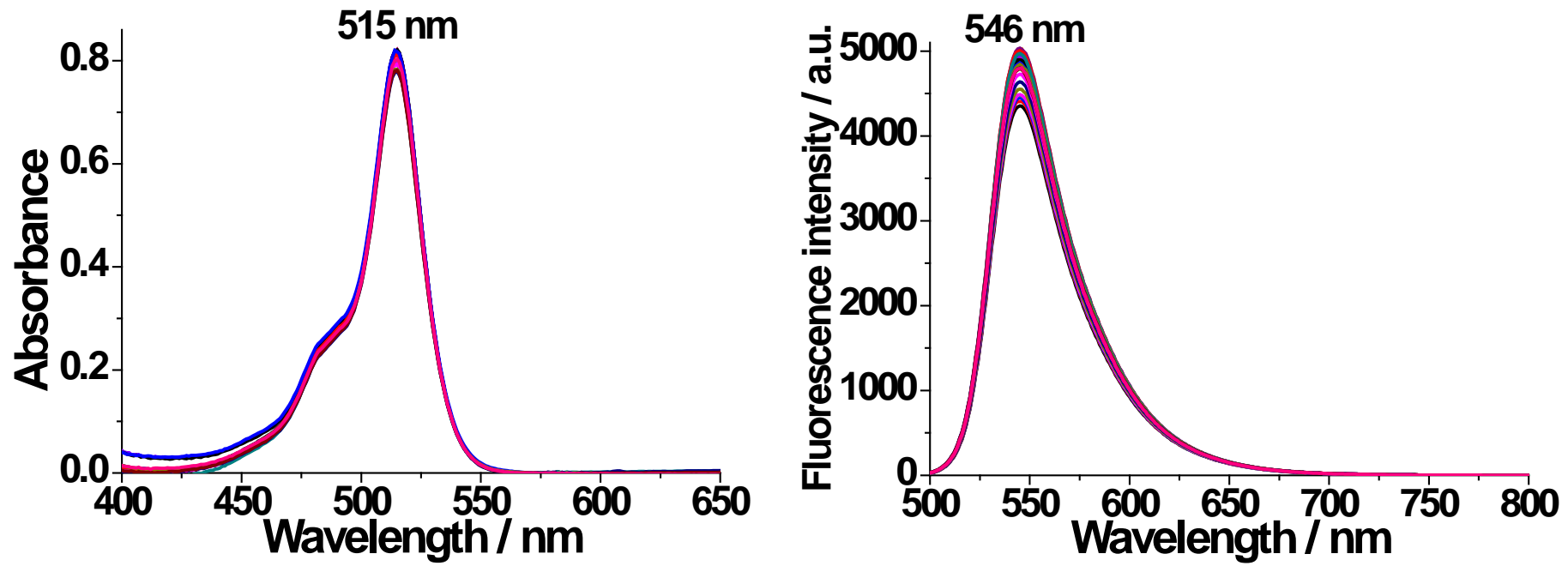

Figure S17. Time-dependent absorption (left) and fluorescence emission (right) spectra of $3 \mathbf{b}$ in $\mathrm{CH}_{3} \mathrm{CN}$ at $25^{\circ} \mathrm{C}$. The spectra were obtained every 1 hour (0-12 hours). [3b] = $10 \mu \mathrm{M}$. Excited at $470 \mathrm{~nm}$. 

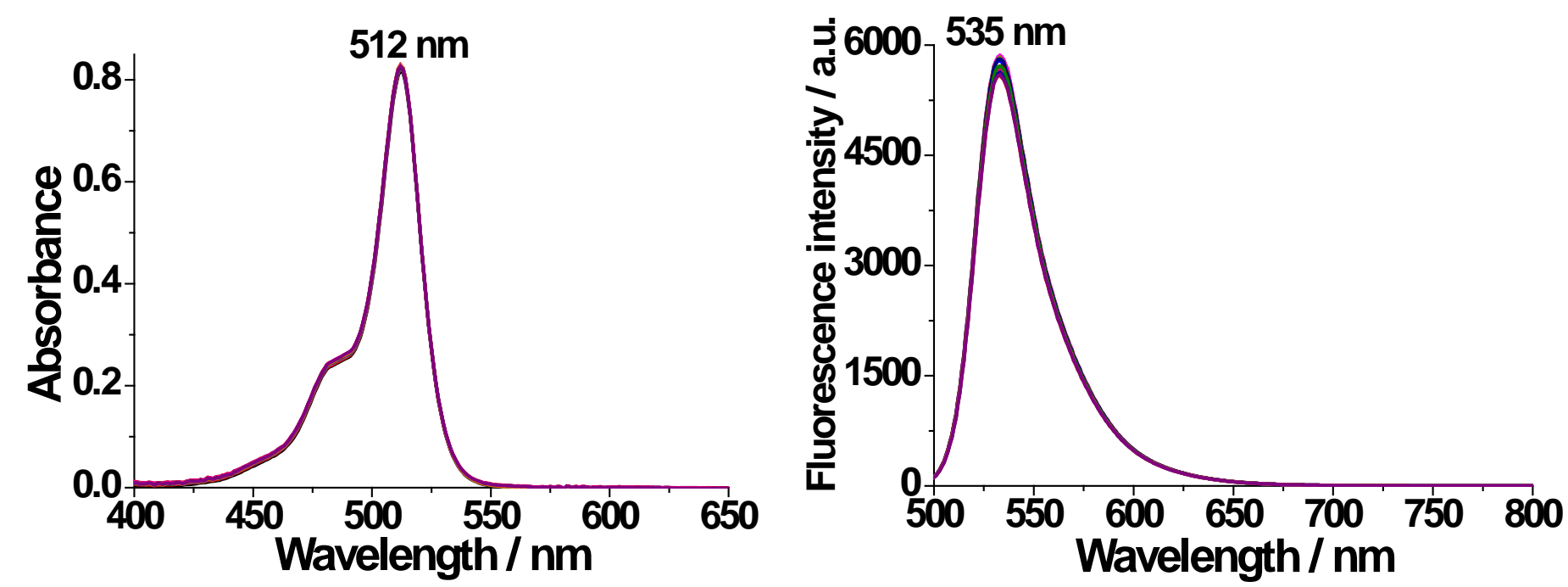

Figure S18. Time-dependent absorption (left) and fluorescence emission (right) spectra of $3 \mathbf{c}$ in $\mathrm{CH}_{3} \mathrm{CN}$ at $25^{\circ} \mathrm{C}$. The spectra were obtained every 1 hour (0-12 hours). [3c] $=10 \mu \mathrm{M}$. Excited at $470 \mathrm{~nm}$. 


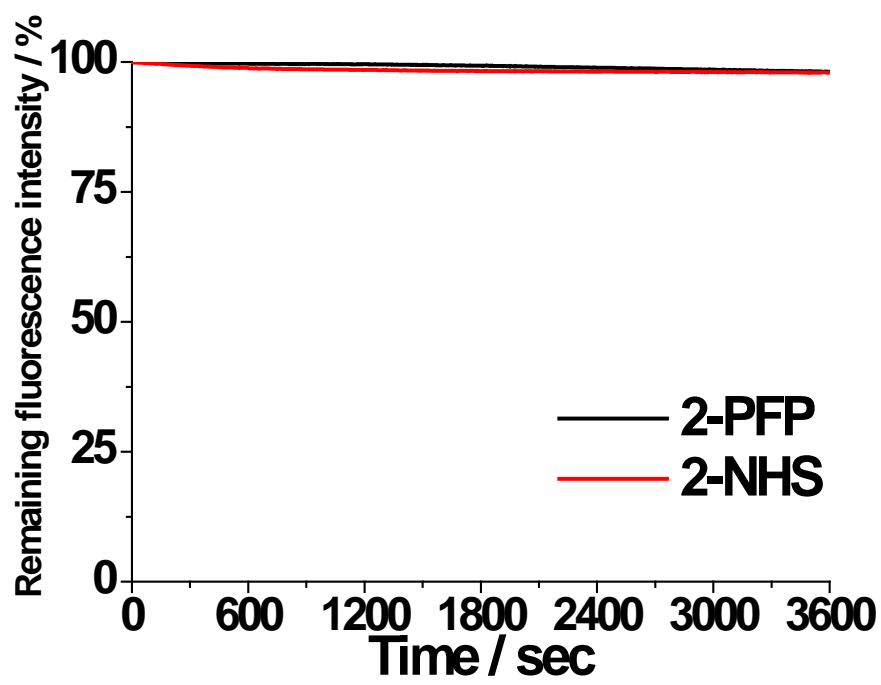

Figure S19. Photostability of 2-PFP (black line) and 2-NHS (red line) in $\mathrm{CH}_{3} \mathrm{CN}$. The remaining fluorescence emission intensities of 2-PFP and 2-NHS as a function of irradiation time. Irradiated at 470 nm. Fluorescence intensity was measured at $615 \mathrm{~nm}$. [2-PFP $]=[2-\mathbf{N H S}]=10 \mu \mathrm{M}$

(d) Photostability of meso-amide BODIPYs $3 a-3 c$ in $\mathrm{CH}_{3} \mathrm{CN}$

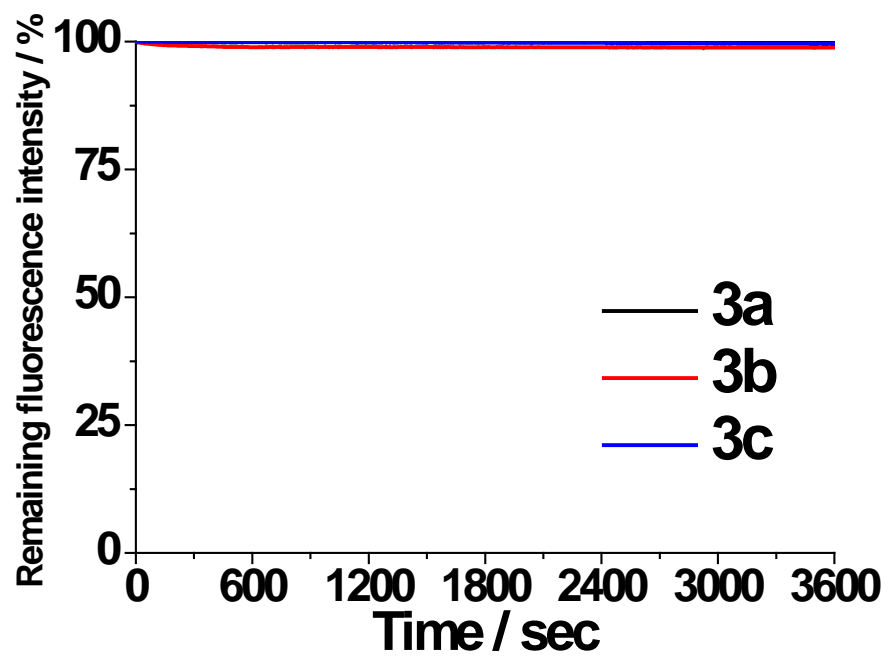

Figure S20. Photostability of 3a-3c in $\mathrm{CH}_{3} \mathrm{CN}$. The remaining fluorescence emission intensities of 3a-3c as a function of irradiation time. Irradiated at $470 \mathrm{~nm}$. Fluorescence intensity was measured at $551 \mathrm{~nm}$ for 3a (black line), $546 \mathrm{~nm}$ for $\mathbf{3 b}$ (red line) and $535 \mathrm{~nm}$ for 3c (blue line). [3a $]=[3 \mathbf{b}]=[\mathbf{3 c}]=10 \mu \mathrm{M}$ 


\section{Applications of 2-PFP as a Solid-State Indicator for Volatile Organic Amines}

\section{(a) Preparation of solid-based strips absorbed 2-PFP}

2-PFP $(0.1 \mathrm{mg})$ and dimethyl polyethylene glycol were dissolved in $116 \mu \mathrm{L}$ of $\mathrm{CH}_{2} \mathrm{Cl}_{2}$ to make a stock solution of 2-PFP (2 mM) and dimethyl polyethylene glycol (PEGDME, $0.3 \mathrm{mM}$ ). 2-PFP/dimethyl polyethylene glycolabsorbed paper was prepared by dropping an amount of $5 \mu \mathrm{L}$ of pre-mixed solution of 2-PFP/dimethyl polyethylene glycol on $1 \times 1 \mathrm{~cm}$ filter paper and drying under air.

\section{(b) Reactivity and selectivity studies toward various amine vapors and organic solvent vapors}

Various amine gases and organic solvents were prepared by charging each analyte $(500 \mu \mathrm{L})$ in a cylindrical vial ( $5 \mathrm{~mL}$ ), and then saturating over 2 hours with a tightly closed lid. The fluorescence change of the filter paper impregnated with 2-PFP/PEGDME upon exposure to each analyte vapor for 1 minute was observed, and all images were taken under a hand-held UV lamp irradiation (365 nm).

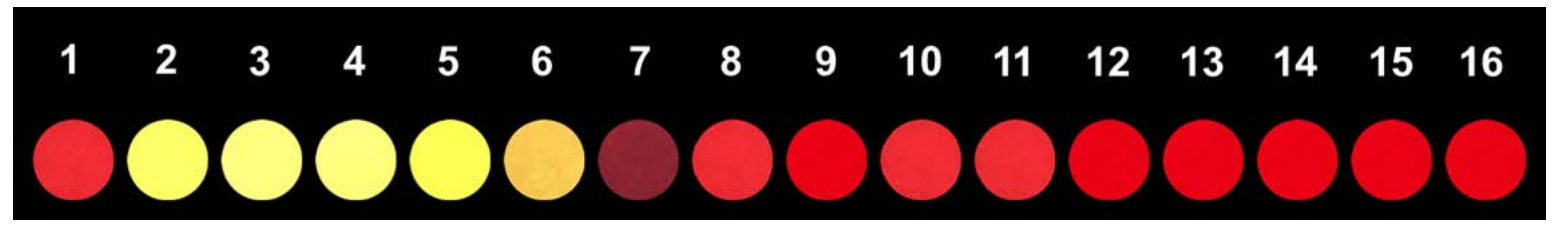

Figure S21. Photographs of fluorescence color (1) 2-PFP only as a control, (2) methylamine, (3) ammonia water, (4) 1,3-diaminopropane, (5) hexylamine, (6) dimethylamine, (7) trimethylamine, (8) pyridine, (9) aniline, (10) toluene, (11) $\mathrm{CH}_{2} \mathrm{Cl}_{2}$, (12) EtOH, (13) $\mathrm{CH}_{3} \mathrm{CN}$, (14) THF, (15) trifluoroacetic acid (TFA), (16) $\mathrm{H}_{2} \mathrm{O}$. Exposure time $=1 \mathrm{~min}$.

\section{(c) Application to fluorogenic detection of food freshness}
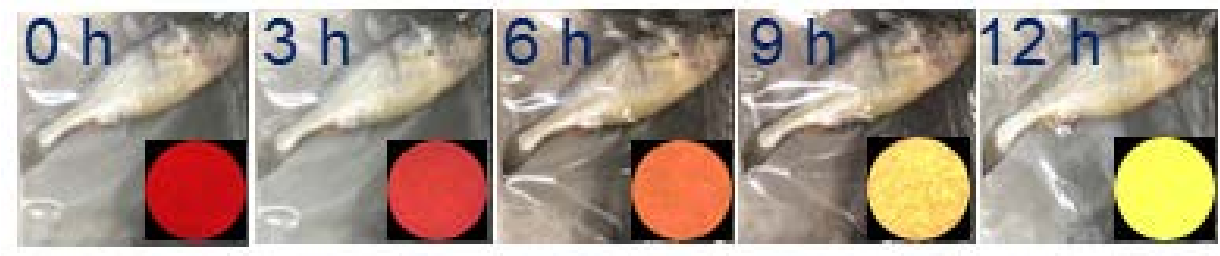

Figure S22. Detection of fish spoilage using 2-PFP. Photographs of the filter-paper embedded with 2PFP/PEGDME upon exposure to a white croaker during incubation in a plastic bag at room temperature for $12 \mathrm{~h}$ (left to right, 0-12 h). Exposure time $=5 \mathrm{~min}$. Fluorescence response images were taken under UV irradiation (365 nm). 
6. Reaction of 2-NHS with L-Lysine and Other L-Amino Acids in Aqueous Buffer

(a) Aggregate formation of 2-NHS in aqueous buffer solution

Absorption and fluorescence emission spectra of 2-NHS in $\mathrm{CH}_{3} \mathrm{CN}-\mathrm{PBS}$ mixtures
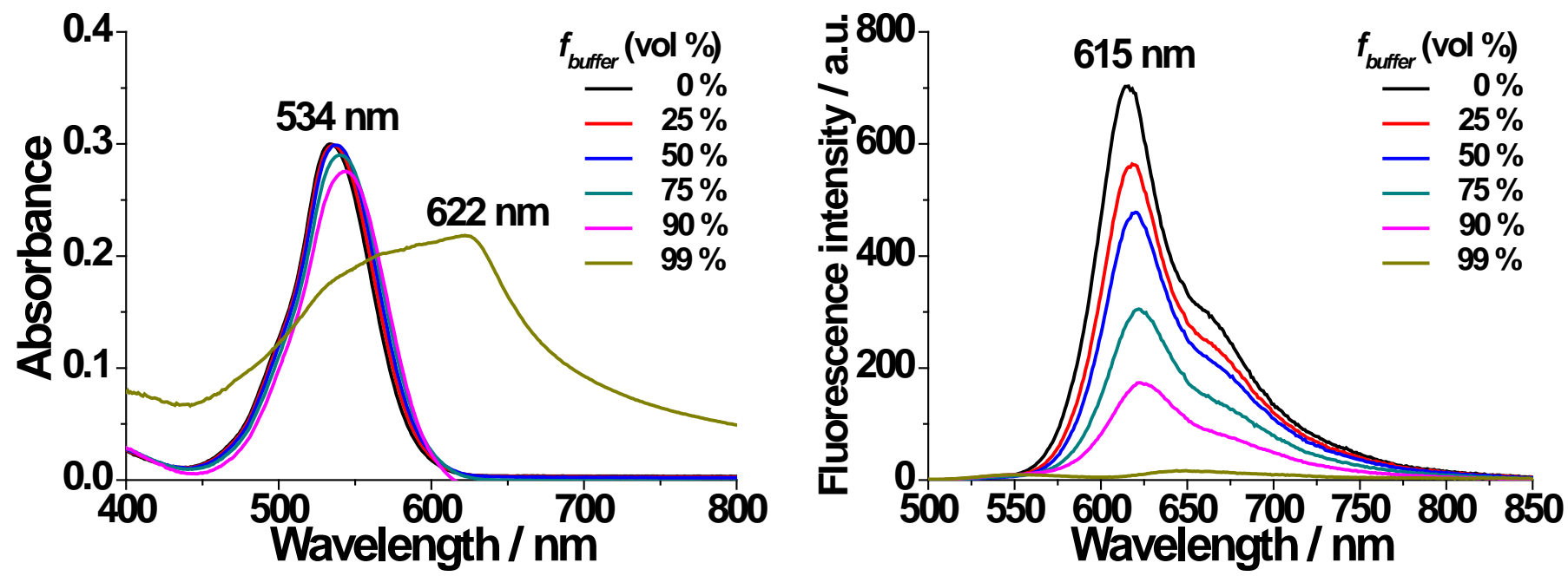

Figure S23. Absorption (left) and fluorescence emission (right) spectra of 2-NHS (5 $\mu \mathrm{M})$ in $\mathrm{CH}_{3} \mathrm{CN}-\mathrm{PBS}$ buffer (10 mM, pH 7.4) mixtures with different buffer fraction ( $\left.f_{\text {buffer }}(\mathrm{vol} \%) ; 0,25,50,75,90,99 \%\right)$ at $25{ }^{\circ} \mathrm{C}$. Excited at $470 \mathrm{~nm}$.

Absorption and fluorescence emission spectra of meso-amide BODIPY $3 \boldsymbol{b}$ in $\mathrm{CH}_{3} \mathrm{CN}$-PBS mixtures
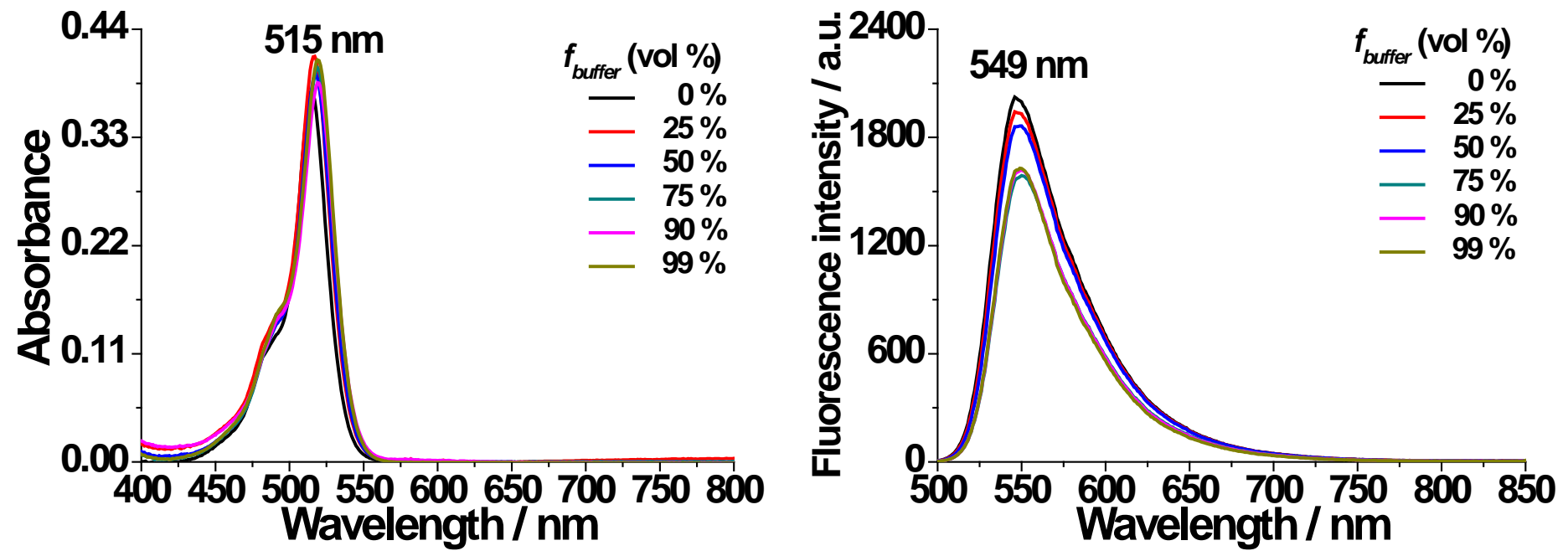

Figure S24. Absorption (left) and fluorescence emission (right) spectra of meso-amide BODIPY $3 \mathbf{b}(5 \mu \mathrm{M})$ in $\mathrm{CH}_{3} \mathrm{CN}-\mathrm{PBS}$ buffer (10 mM, pH 7.4) mixtures with different buffer fraction ( $\left.f_{\text {buffer }}(\mathrm{vol} \%) ; 0,25,50,75,90,99 \%\right)$ at $25{ }^{\circ} \mathrm{C}$. Excited at $470 \mathrm{~nm}$. 

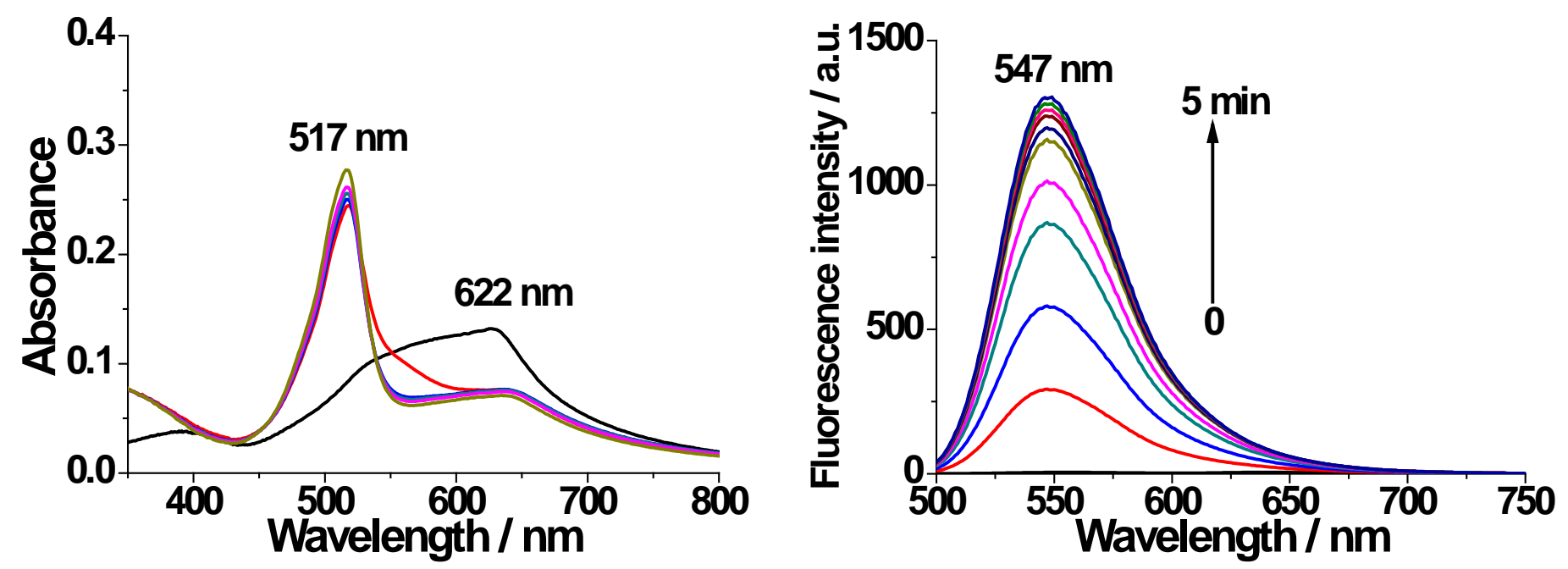

Figure S25. Time-dependent absorption (left) and fluorescence emission (right) spectra of 2-NHS (5 $\mu \mathrm{M})$ upon addition of lysine $(100 \mu \mathrm{M})$ in PBS solution $\left(10 \mathrm{mM}, \mathrm{pH} 7.4,1 \% \mathrm{CH}_{3} \mathrm{CN}\right)$ at $25^{\circ} \mathrm{C}$. The spectra were obtained every $30 \mathrm{sec}(0-5 \mathrm{~min})$. Excited at $470 \mathrm{~nm}$.
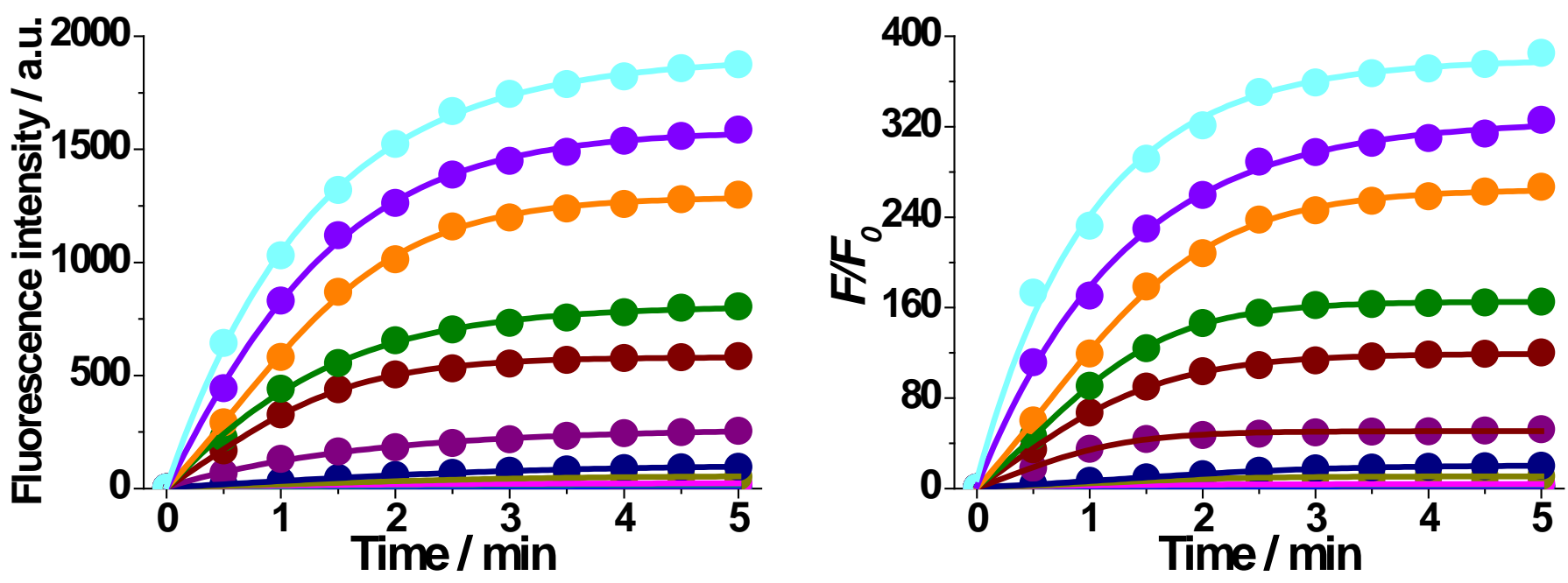

Figure S26. Time-dependent fluorescence intensity of 2-NHS (5 $\mu \mathrm{M})$ upon addition of different amounts of lysine (from bottom to top: 0, 0.25, 0.5, 1, 2, 5, 10, 25, 50, 75, 100, 250, $500 \mu \mathrm{M})$ in PBS solution (10 mM, pH 7.4, 1\% $\left.\mathrm{CH}_{3} \mathrm{CN}\right)$ at $25^{\circ} \mathrm{C}$. The spectra were obtained every $30 \mathrm{sec}(0-5 \mathrm{~min})$, and fluorescence intensity at $547 \mathrm{~nm}$ was measured. Excited at $470 \mathrm{~nm}$. 


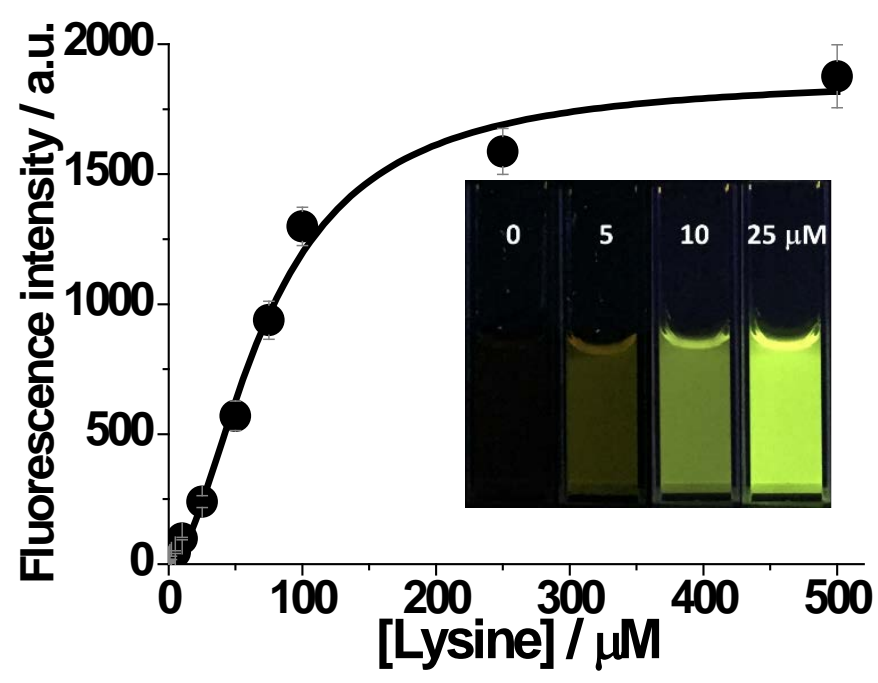

Figure S27. Fluorescence emission intensity of 2-NHS $(5 \mu \mathrm{M})$ upon addition of lysine at different amounts (0, 0.25, 0.5, 1, 2, 5, 10, 25, 50, 75, 100, 250, $500 \mu \mathrm{M})$ in PBS solution (10 mM, pH 7.4, 1\% $\left.\mathrm{CH}_{3} \mathrm{CN}\right)$ at $25^{\circ} \mathrm{C}$. The spectra were obtained 5 min after the addition of lysine to each solution, the fluorescence intensity at $547 \mathrm{~nm}$ was measured. Excited at $470 \mathrm{~nm}$. Inset: Photographs of 2-NHS upon the 5 min incubation with lysine (0, 5, 10, 25 $\mu \mathrm{M}$ ) under UV irradiation (365 nm). 

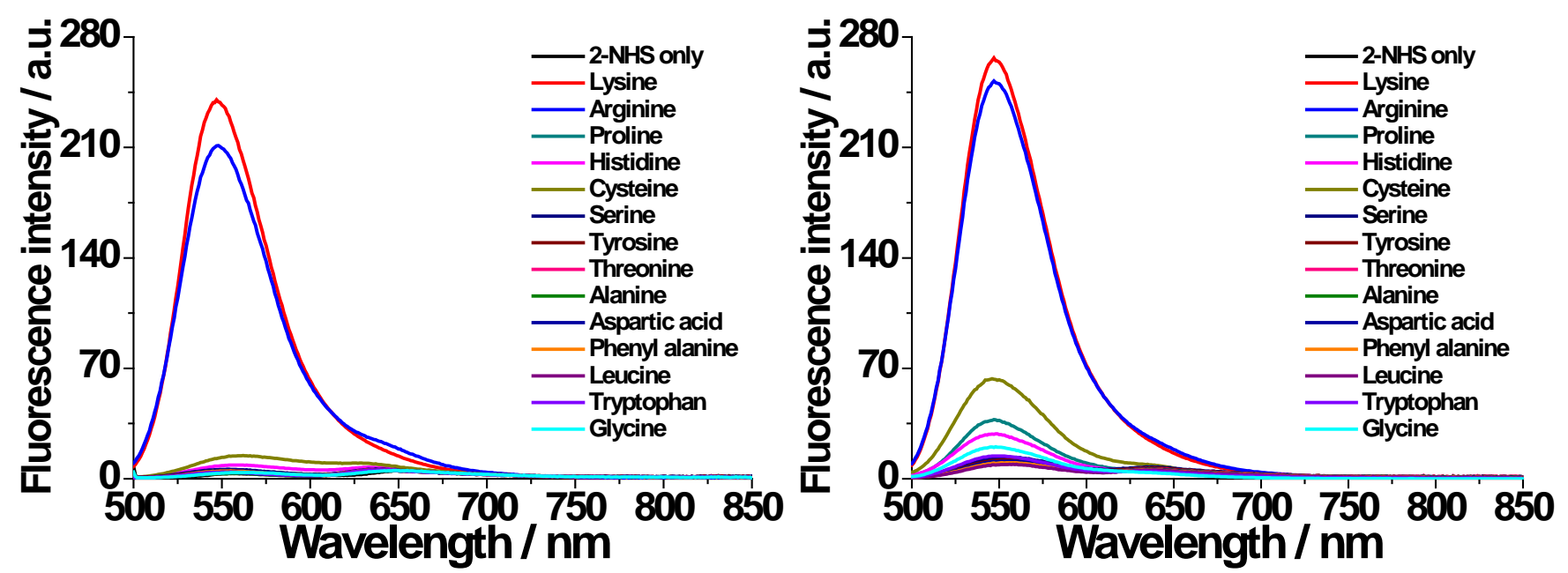

Figure S28. Fluorescence emission spectra of 2-NHS (5 $\mu \mathrm{M})$ upon addition of various amino acids (5 equiv) in PBS solution $\left(10 \mathrm{mM}\right.$, pH 7.4, 1\% $\left.\mathrm{CH}_{3} \mathrm{CN}\right)$ at $25{ }^{\circ} \mathrm{C}$. Excited at $470 \mathrm{~nm}$. [Amino acid] $=25 \mu \mathrm{M}$. Incubation time $=5 \mathrm{~min}$ (left) and $30 \mathrm{~min}$ (right).

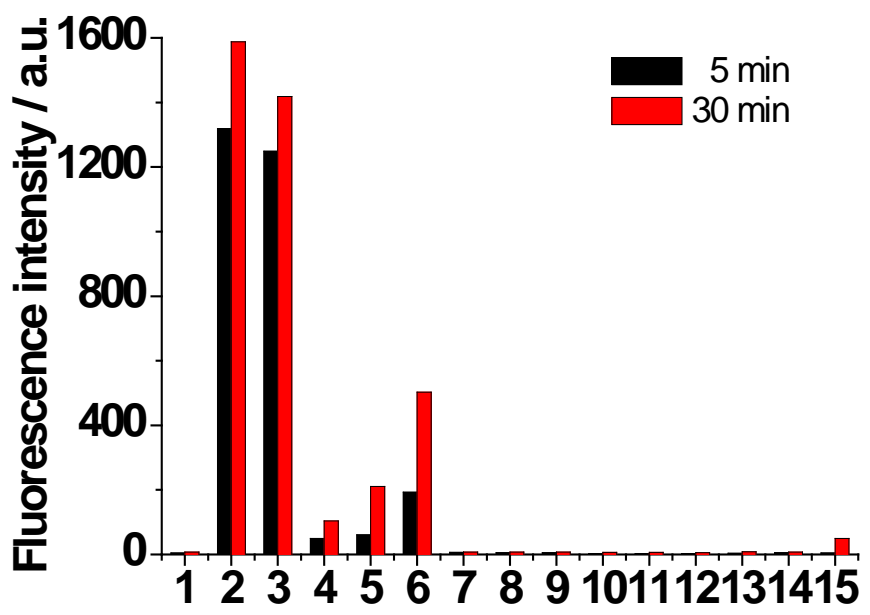

Figure S29. Fluorescence responses of 2-NHS (5 $\mu \mathrm{M})$ to various amino acids (20 equiv); (1) 2-NHS only (control), (2) lysine, (3) arginine, (4) proline, (5) histidine, (6) cysteine, (7) serine, (8) tyrosine, (9) threonine, (10) alanine, (11) aspartic acid, (12) phenyl alanine, (13) leucine, (14) tryptophan, (15) glycine. Bars represent relative responses at 5 (black) and $30 \mathrm{~min}$ (red) after the addition of each analyte. Emission signals were recorded at 547 $\mathrm{nm}\left(\lambda_{\mathrm{ex}}=470 \mathrm{~nm}\right)$. All data were obtained in PBS buffer $\left(10 \mathrm{mM}, \mathrm{pH} 7.4,1 \% \mathrm{CH}_{3} \mathrm{CN}\right)$ at $25^{\circ} \mathrm{C}$. [Amino acid] $=$ $100 \mu \mathrm{M}$. 
(d) Identification of reaction product of 2-NHS and amino acids by HPLC-MS

Reaction with lysine (Lys)

(a)

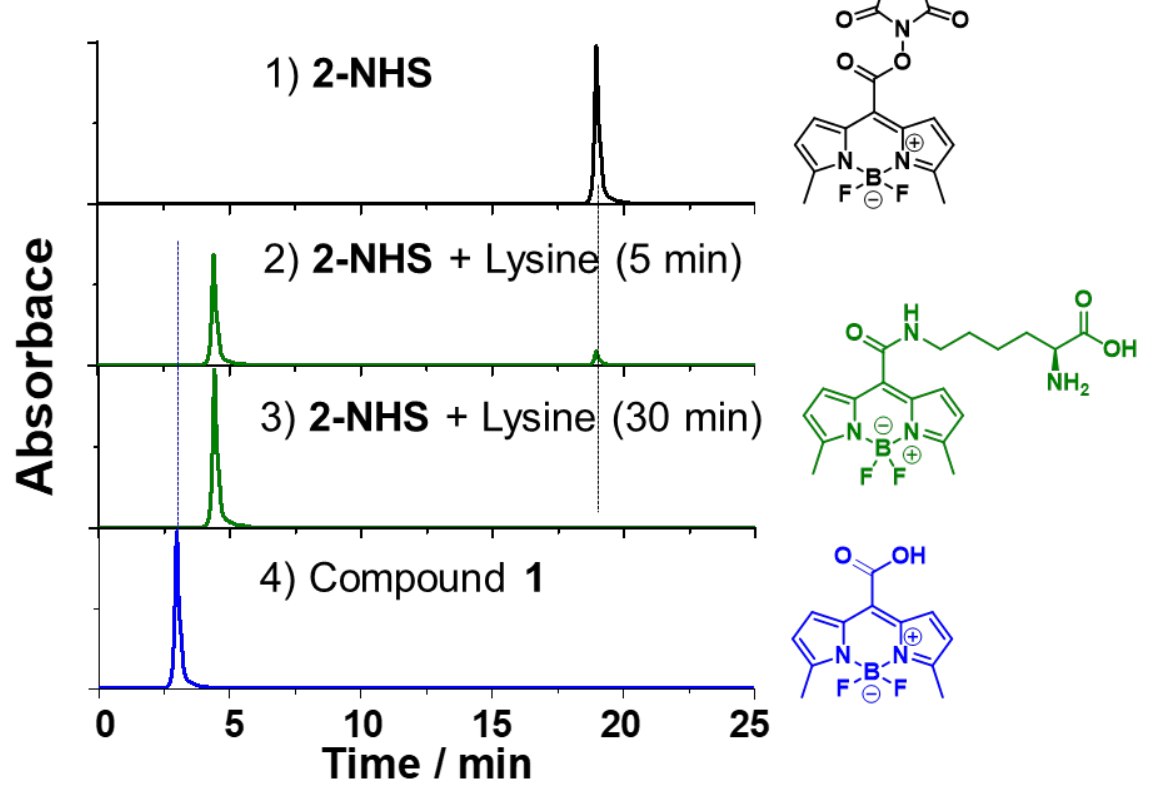

(b) $4.4 \mathrm{~min}$

(c) $18.9 \mathrm{~min}$
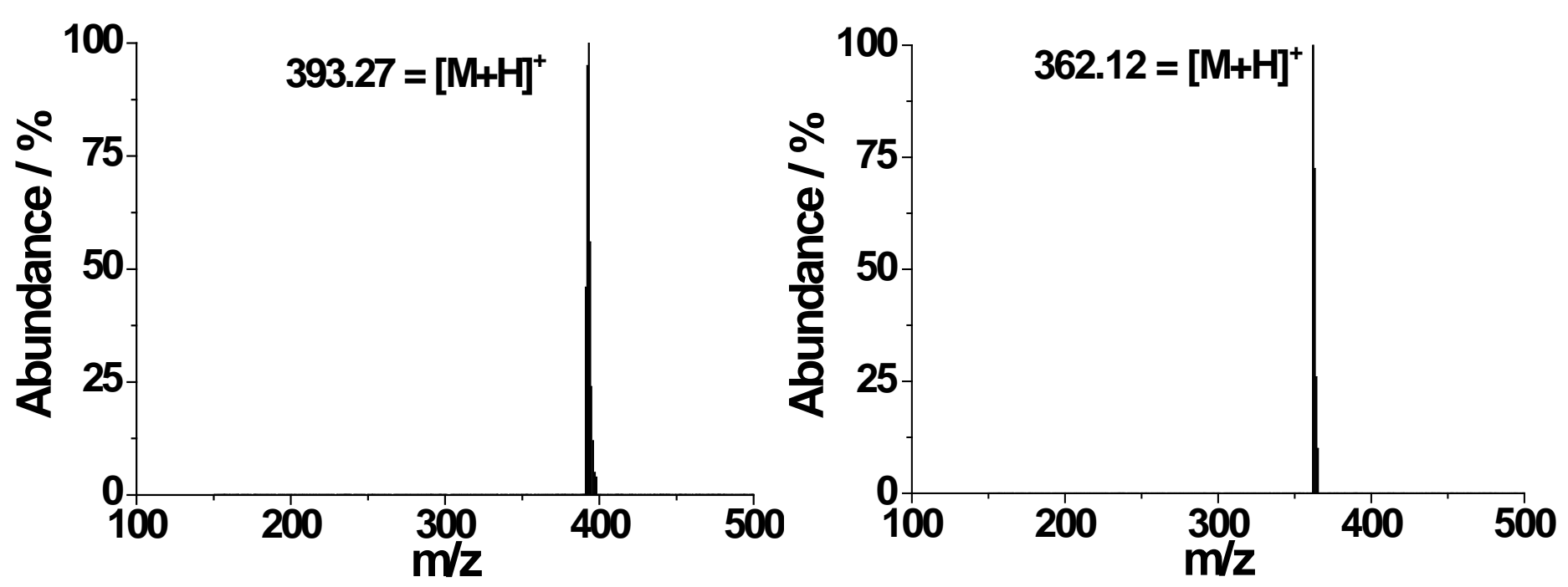

Figure S30. (a) HPLC chromatograms of 2-NHS before (1) and after treatment with lysine for 5 min (2) and 30 min (3) at $25^{\circ} \mathrm{C}$; compound 1 (4). The samples were analyzed by LC-MS with a linear gradient elution (from 20 to $100 \% \mathrm{~A}, \mathrm{~A}: \mathrm{CH}_{3} \mathrm{CN}, \mathrm{B}$ : deionized water with $0.1 \%$ formic acid, flow rate $0.3 \mathrm{~mL} / \mathrm{min}$, UV-Vis: $500 \pm 20 \mathrm{~nm}$ ). ESI-MS spectra of the peak of retention time at (b) $4.4 \mathrm{~min}$, and (c) $18.9 \mathrm{~min}$. MW of the retention time at 2.9 min is 265.07, which corresponds to $[\mathrm{M}+\mathrm{H}]^{+}$for $\mathbf{1}$, MW of the retention time at 4.4 min is 393.27, which corresponds to $[\mathrm{M}+\mathrm{H}]^{+}$for 2-NHS/lysine conjugate, MW of the retention time at 18.9 min is 362.12, which corresponds to $[\mathrm{M}+\mathrm{H}]^{+}$for 2-NHS. [2-NHS] = [1] = $5 \mu \mathrm{M}$. [lysine] = $25 \mu \mathrm{M}$. Yield (2-NHS/lysine, 30 min): $97 \%$. 
(a)
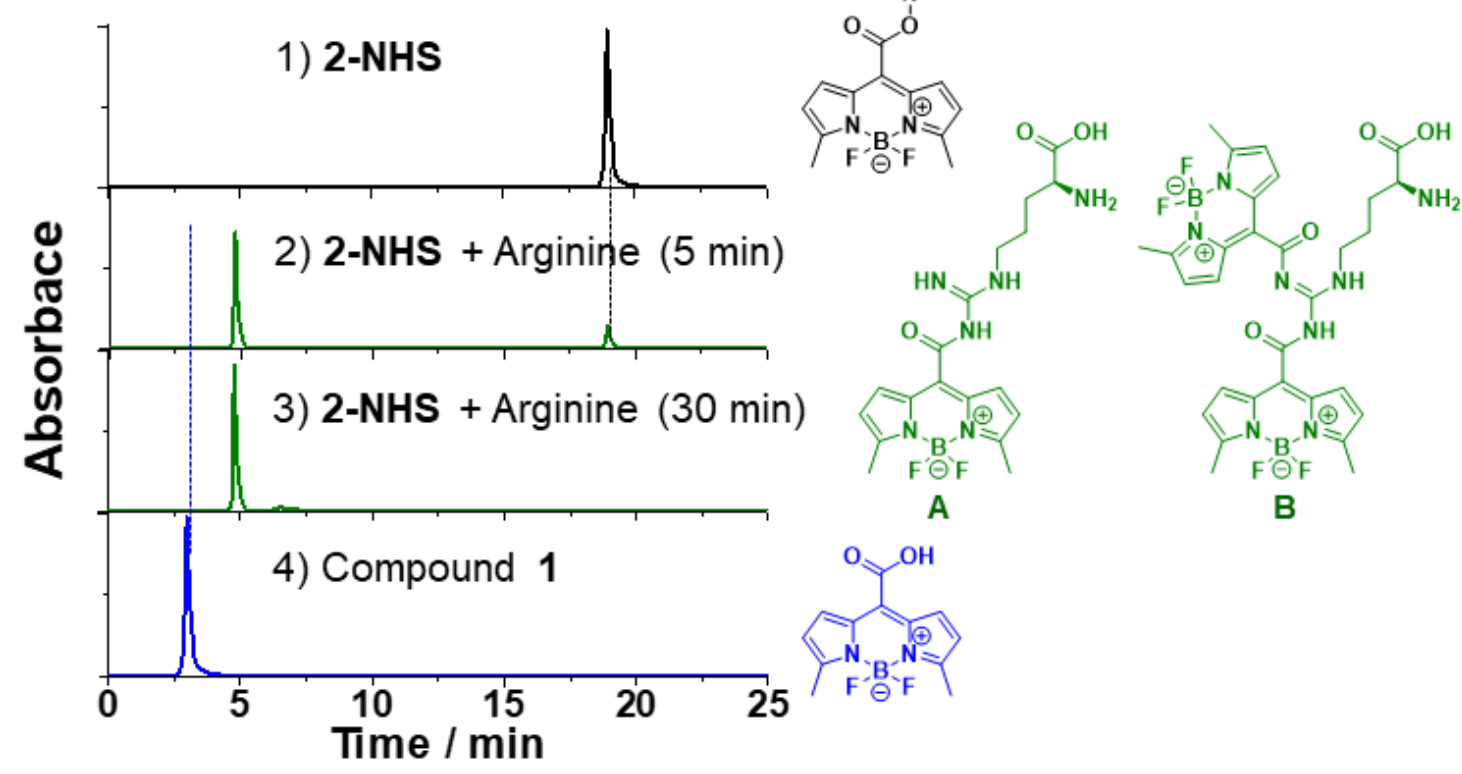

(b) $4.7 \mathrm{~min}$

(c) $6.5 \mathrm{~min}$
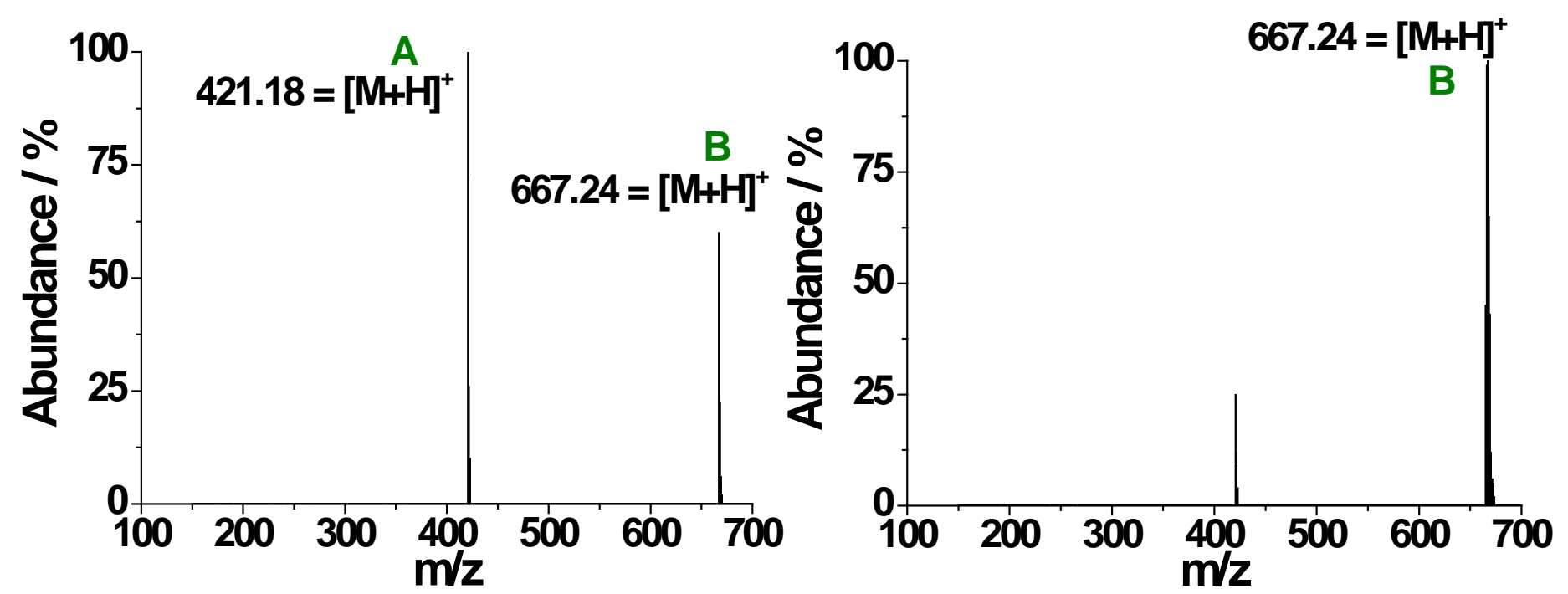

Figure S31. (a) HPLC chromatograms of 2-NHS before (1) and after treatment with arginine for 5 min (2) and 30 min (3) at $25{ }^{\circ} \mathrm{C}$; compound 1 (4). The samples were analyzed by LC-MS with a linear gradient elution (from 20 to $100 \% \mathrm{~A}, \mathrm{~A}: \mathrm{CH}_{3} \mathrm{CN}$, B: deionized water with $0.1 \%$ formic acid, flow rate $0.3 \mathrm{~mL} / \mathrm{min}$, UV-Vis: $500 \pm 20$ $\mathrm{nm}$ ). ESI-MS spectra of the peak of retention time at (b) $4.7 \mathrm{~min}$ and (c) $6.5 \mathrm{~min}$. MW of the retention time at 2.9 min is 265.07, which corresponds to [M+H] $]^{+}$for compound 1, MWs of the retention time at (b) 4.7 min and (c) $6.5 \mathrm{~min}$ are 421.18 and 667.24, which correspond to $[\mathrm{M}+\mathrm{H}]^{+}$for 2-NHS (mono)/arginine conjugate (A), and 2NHS (di)/arginine conjugate (B), MW of the retention time at $18.9 \mathrm{~min}$ is 362.12 , which corresponds to [M+H] ${ }^{+}$ for 2-NHS. [2-NHS] = [1] = $5 \mu \mathrm{M}$. [arginine] = $25 \mu \mathrm{M}$. Yield (2-NHS/arginine, $30 \mathrm{~min}$ ): 95\%. 
(a)

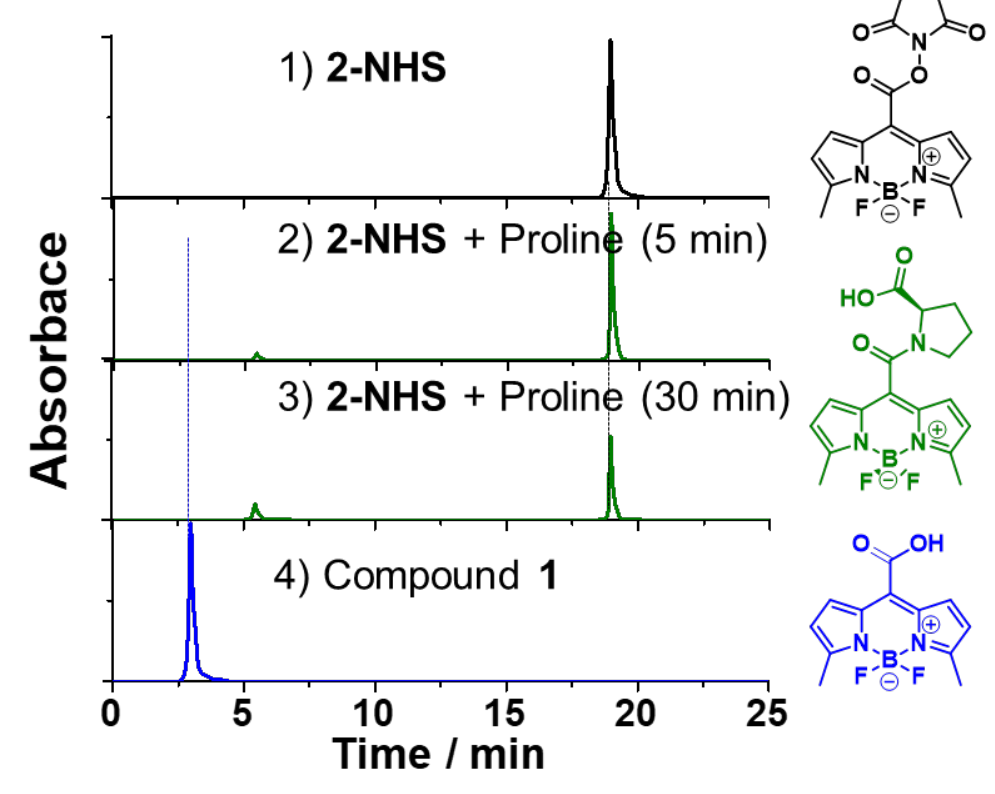

(b) $5.5 \mathrm{~min}$

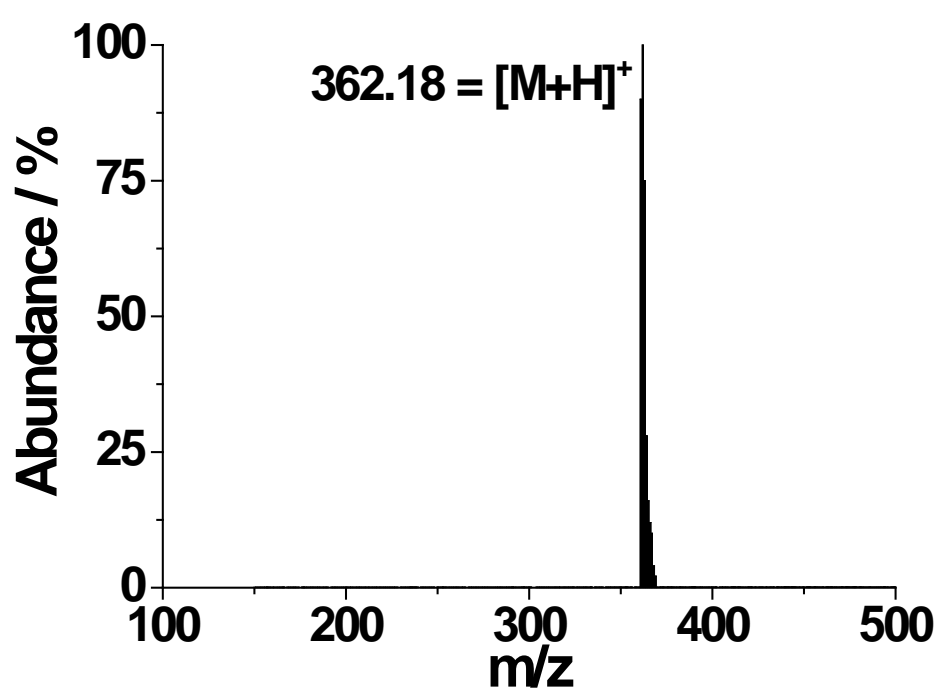

Figure S32. (a) HPLC chromatograms of 2-NHS before (1) and after treatment with proline for 5 min (2) and 30 $\min (3)$ at $25{ }^{\circ} \mathrm{C}$; compound $\mathbf{1}$ (4). The samples were analyzed by LC-MS with a linear gradient elution (from 20 to $100 \% \mathrm{~A}, \mathrm{~A}: \mathrm{CH}_{3} \mathrm{CN}$, B: deionized water with $0.1 \%$ formic acid, flow rate $0.3 \mathrm{~mL} / \mathrm{min}$, UV-Vis: $500 \pm 20 \mathrm{~nm}$ ). ESI-MS spectra of the peak of retention time at (b) $5.5 \mathrm{~min}$. MW of the retention time at $2.9 \mathrm{~min}$ is 265.07, which corresponds to $[\mathrm{M}+\mathrm{H}]^{+}$for compound $\mathbf{1}, \mathrm{MW}$ of the retention time at $5.5 \mathrm{~min}$ is 362.18 , which corresponds to $[\mathrm{M}+\mathrm{H}]^{+}$for 2-NHS/proline conjugate, MW of the retention time at $18.9 \mathrm{~min}$ is 362.12 , which corresponds to $[\mathrm{M}+\mathrm{H}]^{+}$for 2-NHS. [2-NHS] $=[1]=5 \mu \mathrm{M}$. [proline] = $25 \mu \mathrm{M}$. Yield (2-NHS/proline, $30 \mathrm{~min}$ ): 7\%. 
(a)

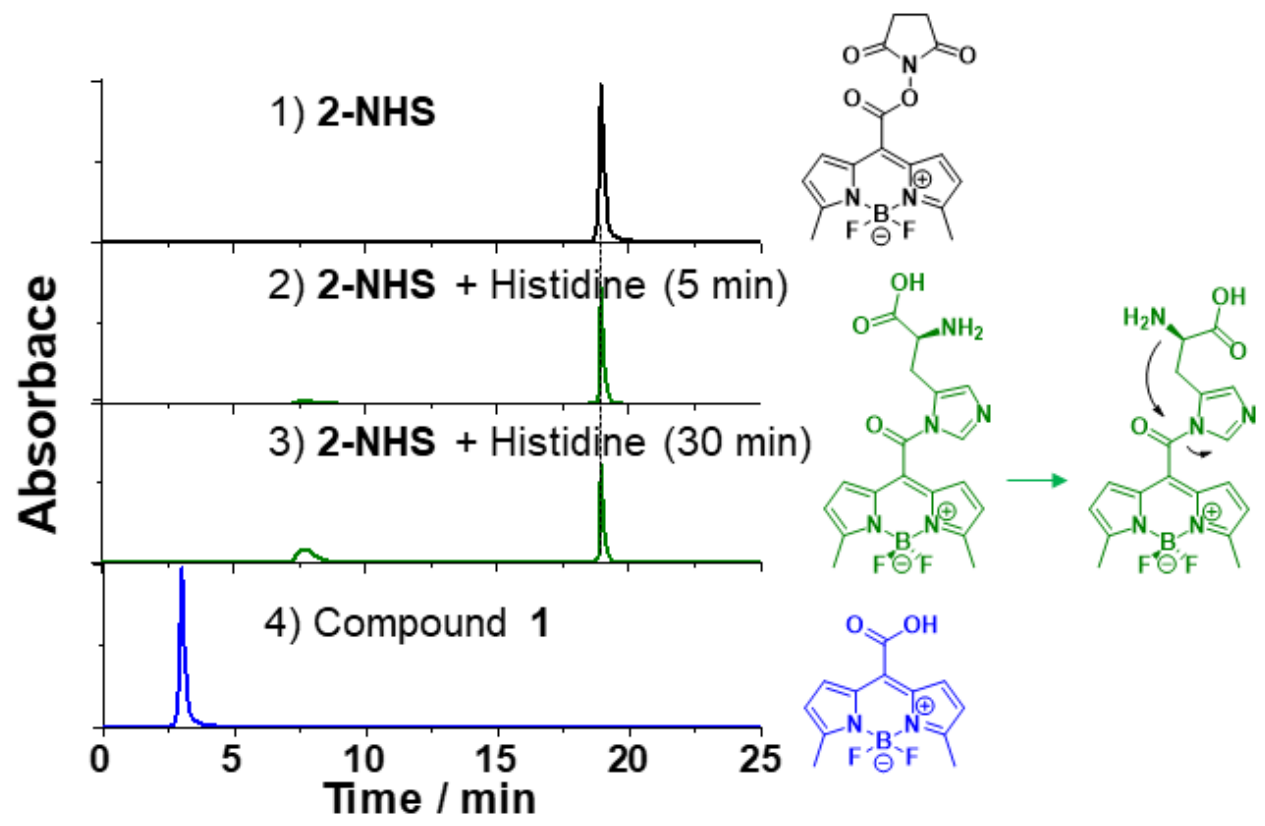

(b) $7.6 \mathrm{~min}$

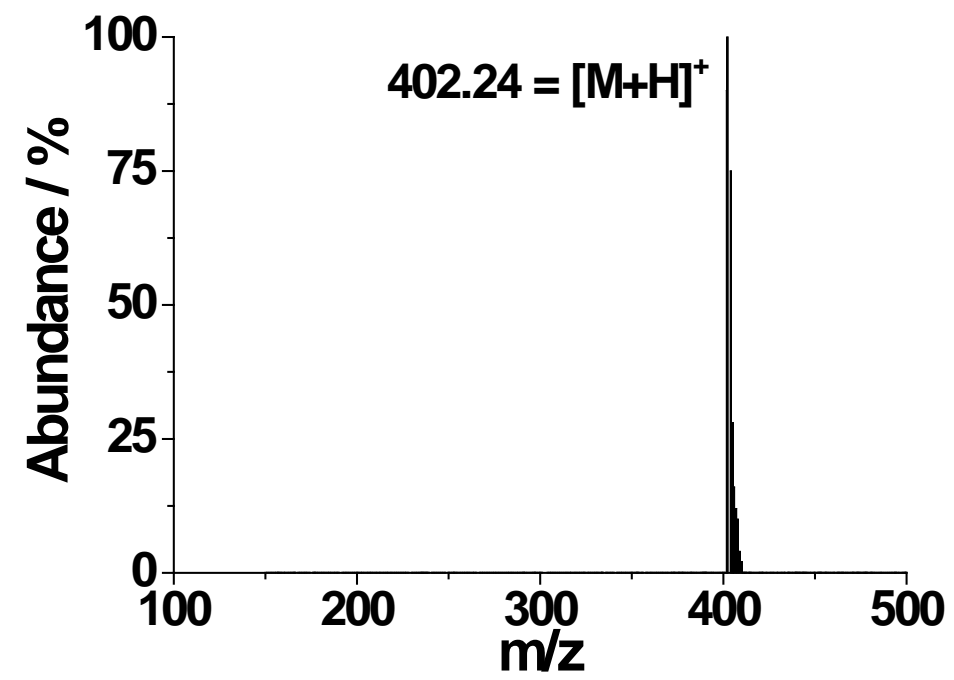

Figure S33. (a) HPLC chromatograms of 2-NHS before (1) and after treatment with histidine for 5 min (2) and $30 \mathrm{~min}$ (3) at $25^{\circ} \mathrm{C}$; compound 1 (4). The samples were analyzed by LC-MS with a linear gradient elution (from 20 to $100 \%$ A, A: $\mathrm{CH}_{3} \mathrm{CN}$, B: deionized water with $0.1 \%$ formic acid, flow rate $0.3 \mathrm{~mL} / \mathrm{min}$, UV-Vis: $500 \pm 20$ $\mathrm{nm}$ ). ESI-MS spectra of the peak of retention time at (b) $7.6 \mathrm{~min}$. MW of the retention time at $2.9 \mathrm{~min}$ is 265.07 , which corresponds to $[\mathrm{M}+\mathrm{H}]^{+}$for compound $\mathbf{1}$, MW of the retention time at $7.6 \mathrm{~min}$ is 402.24 , which corresponds to $[\mathrm{M}+\mathrm{H}]^{+}$for 2-NHS/histidine conjugate, MW of the retention time at $18.9 \mathrm{~min}$ is 362.12 , which corresponds to $[\mathrm{M}+\mathrm{H}]^{+}$for 2-NHS. [2-NHS] $=[\mathbf{1}]=5 \mu \mathrm{M}$. [histidine] $=25 \mu \mathrm{M}$. Yield (2-NHS/histidine, $30 \mathrm{~min}$ ): 9\%. 
(a)

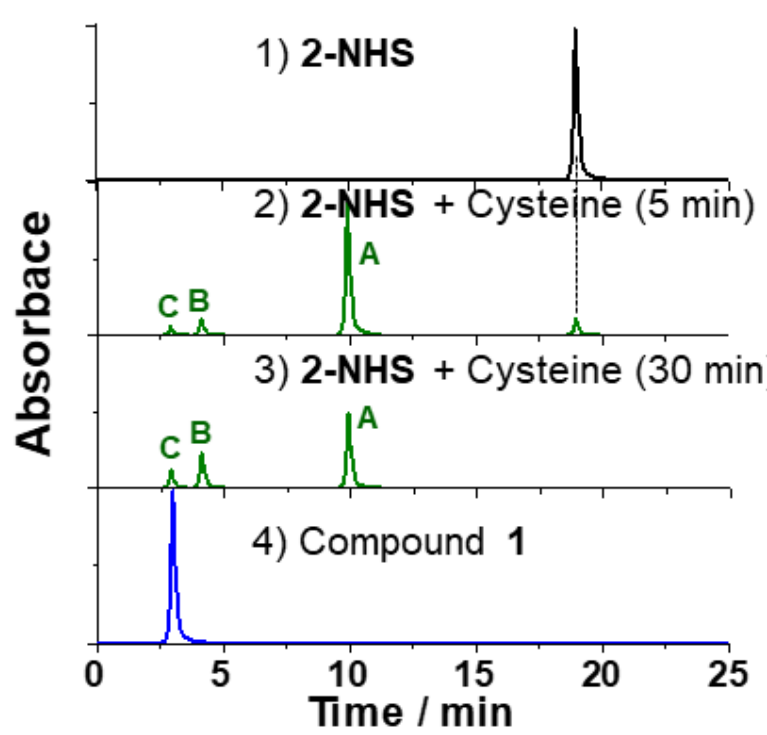

(b) $3.0 \mathrm{~min}$ (c) $4.1 \mathrm{~min}$

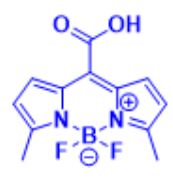

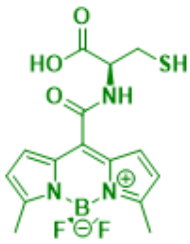

B

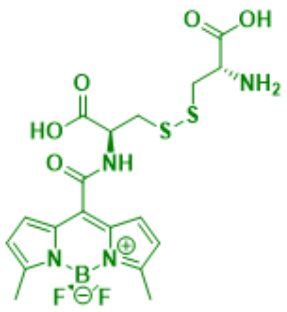

C
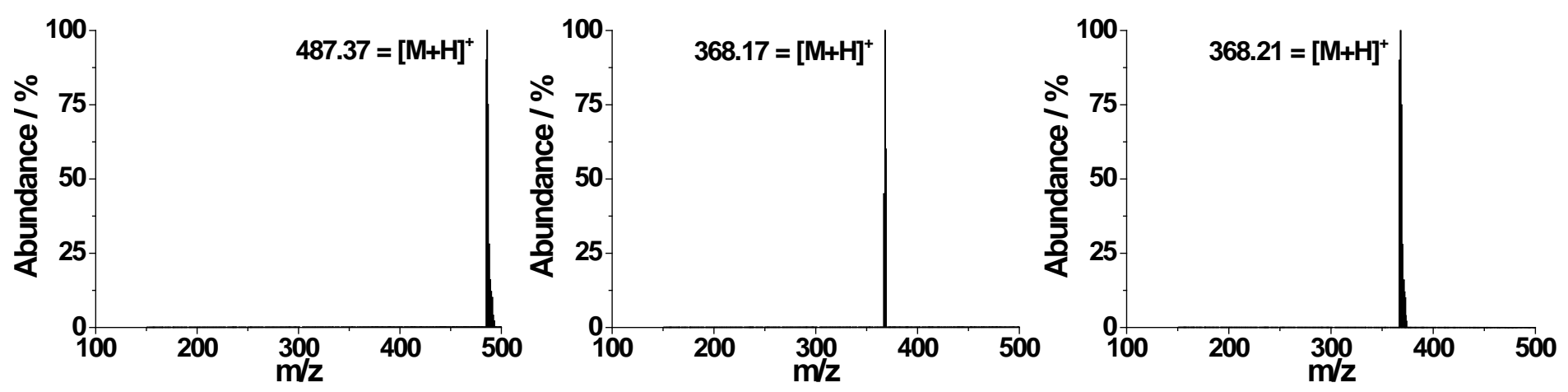

Figure S34. (a) HPLC chromatograms of 2-NHS before (1) and after treatment with cysteine for 5 min (2) and $30 \mathrm{~min}$ (3) at $25^{\circ} \mathrm{C}$; compound 1 (4). The samples were analyzed by LC-MS with a linear gradient elution (from 20 to $100 \% \mathrm{~A}, \mathrm{~A}: \mathrm{CH}_{3} \mathrm{CN}$, B: deionized water with $0.1 \%$ formic acid, flow rate $0.3 \mathrm{~mL} / \mathrm{min}$, UV-Vis: $500 \pm 20$ $\mathrm{nm}$ ). ESI-MS spectra of the peak of retention time at (b) $3.0 \mathrm{~min}$, (c) $4.1 \mathrm{~min}$, and (d) $9.9 \mathrm{~min}$. MW of the retention time at $2.9 \mathrm{~min}$ is 265.07 , which corresponds to $[\mathrm{M}+\mathrm{H}]^{+}$for compound $\mathbf{1}$, MW of the retention time at $3.0 \mathrm{~min}$ is 487.37, which corresponds to $[\mathrm{M}+\mathrm{H}]^{+}$for $2-\mathrm{NHS} /$ cysteine conjugate (amide form, $\mathrm{C}, 7.1 \%$ ), $\mathrm{MW}$ of the retention time at $4.1 \mathrm{~min}$ is 368.17 , which corresponds to $[\mathrm{M}+\mathrm{H}]^{+}$for 2-NHS/cysteine conjugate (amide form, B, 12.8\%), MW of the retention time at $9.9 \mathrm{~min}$ is 368.21 , which corresponds to $[\mathrm{M}+\mathrm{H}]^{+}$for 2 -NHS/cysteine conjugate (thioester form, A, 65\%). [2-NHS] $=[1]=5 \mu \mathrm{M}$. [cysteine $]=25 \mu \mathrm{M}$. 
Determination of kinetic constant for the reaction of 2-NHS with lysine in aqueous buffer solution

Under the pseudo first-order kinetics condition, kinetic rate constant $(k)$ was determined for the reaction between 2-NHS $(5 \mu \mathrm{M})$ and lysine (50 $\mu \mathrm{M}, 10$ equiv) in PBS solution $\left(10 \mathrm{mM}, \mathrm{pH} 7.4,1 \% \mathrm{CH}_{3} \mathrm{CN}\right)$ at $25{ }^{\circ} \mathrm{C}$, by monitoring the fluorescence intensity at $547 \mathrm{~nm}\left(\lambda_{\mathrm{ex}}=470 \mathrm{~nm}\right)$ and fitting the fluorescence intensities to the pseudo first-order equation 2:

$$
\ln \left[\left(F_{\max }-F_{t}\right) / F_{\max }\right]=-k_{\mathrm{obs}} \cdot t
$$

where $F_{t}$ is the fluorescence intensity at $547 \mathrm{~nm}$ at each time interval $(t)$ and $F_{\max }$ is the maximum fluorescence intensity measured after the reaction was completed. The observed rate constant $\left(k_{\mathrm{obs}}\right)$ was estimated from the slope of the pseudo-first order plot for the reaction of 2-NHS $(5 \mu \mathrm{M})$ with lysine $(50 \mu \mathrm{M}$, Figure S35), providing $k_{\mathrm{obs}}=1.11 \mathrm{~min}^{-1}$. This corresponds to the second-order rate constant $(k)$ of $22,200 \mathrm{M}^{-1} \cdot \mathrm{min}^{-1}$.
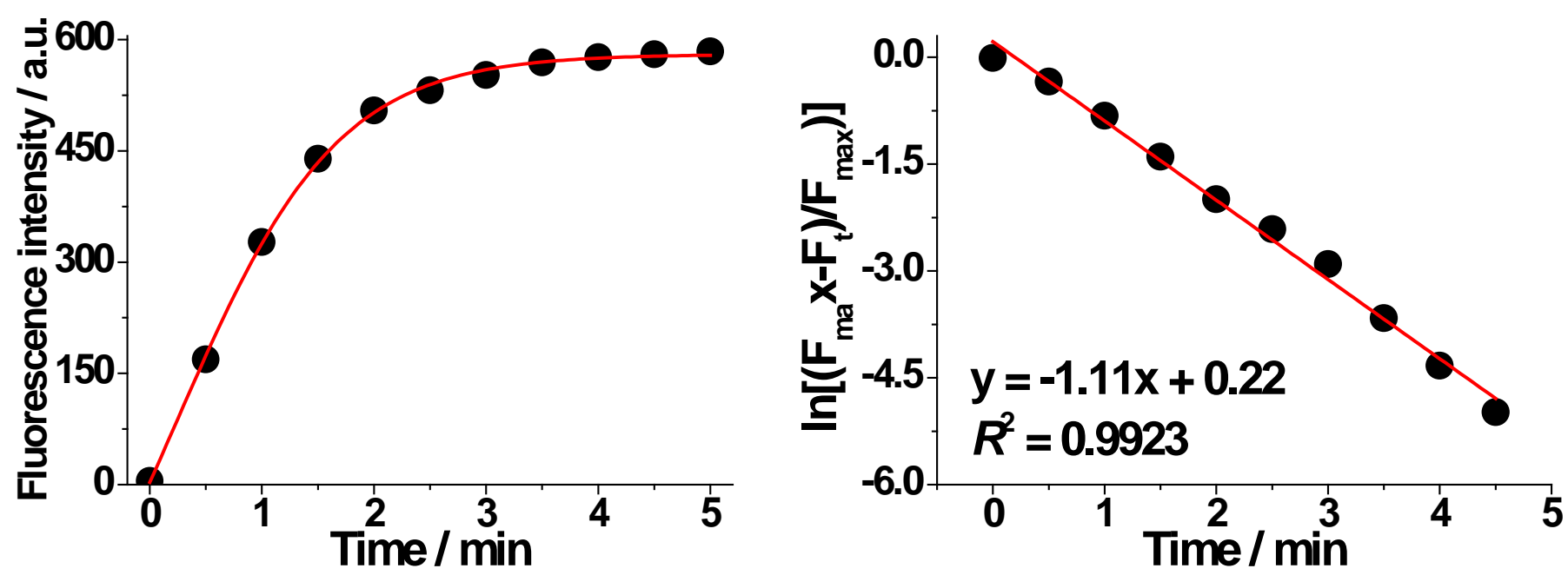

Figure S35. (left) Time-dependent fluorescence intensity of 2-NHS upon addition of lysine in PBS solution (10 $\mathrm{mM}, \mathrm{pH} 7.4,1 \% \mathrm{CH}_{3} \mathrm{CN}$ ) at $25^{\circ} \mathrm{C}$. (right) Pseudo first-order kinetic plot of the reaction of 2-NHS with lysine in PBS solution $\left(10 \mathrm{mM}, \mathrm{pH} 7.4,1 \% \mathrm{CH}_{3} \mathrm{CN}\right)$ at $25^{\circ} \mathrm{C}$. The emission spectra were obtained every 30 sec $(0-5 \mathrm{~min})$, and the fluorescence intensity at $547 \mathrm{~nm}$ was recorded. Excited at $470 \mathrm{~nm}$. [2-NHS] $=5 \mu \mathrm{M}$. [lysine] $=50 \mu \mathrm{M}$. 
7. Stability Studies of 2-NHS and 3b in Aqueous Buffer Solution

(a) Chemical stability of 2-NHS in aqueous buffer solution (pH 7.4 and pH 9.2)
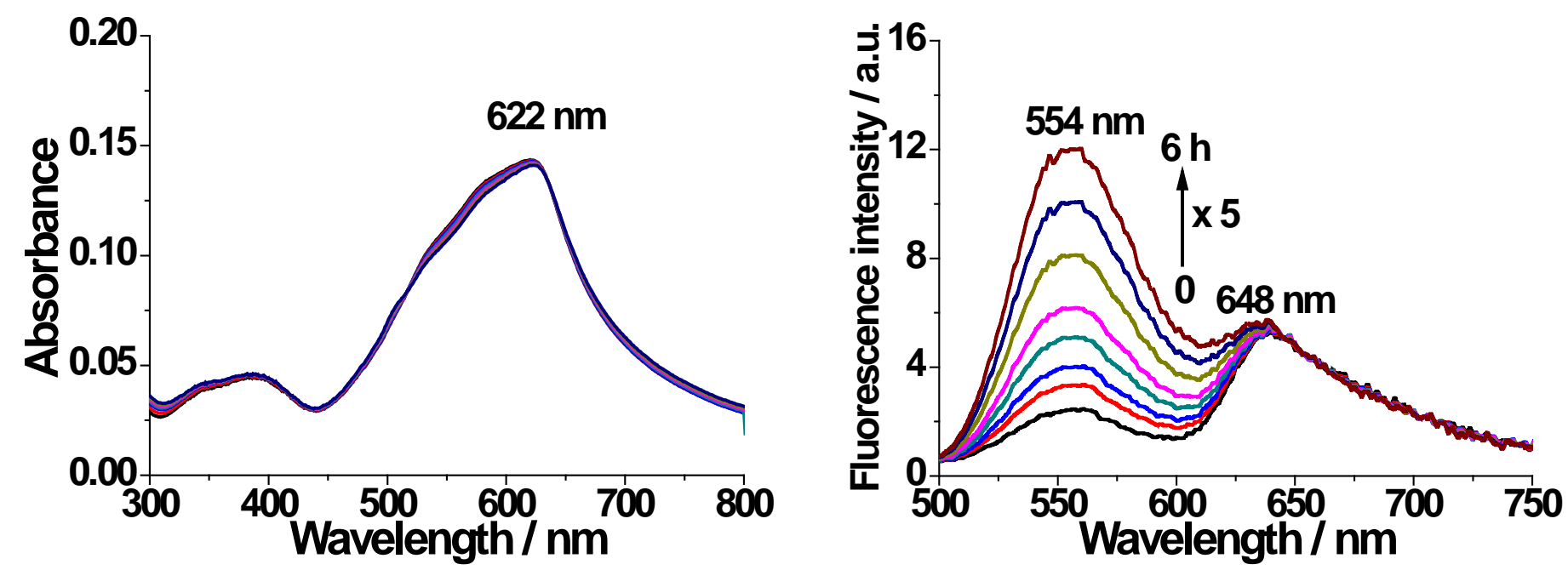

Figure S36. Stability of 2-NHS to hydrolysis. Time-dependent absorption (left) and fluorescence emission (right) spectra of 2-NHS $(5 \mu \mathrm{M})$ in PBS solution $\left(10 \mathrm{mM}, \mathrm{pH} 7.4,1 \% \mathrm{CH}_{3} \mathrm{CN}\right)$ at $25{ }^{\circ} \mathrm{C}$. Incubation time $=0,0.5,1,2$, 3, 4, 5, 6 hours.
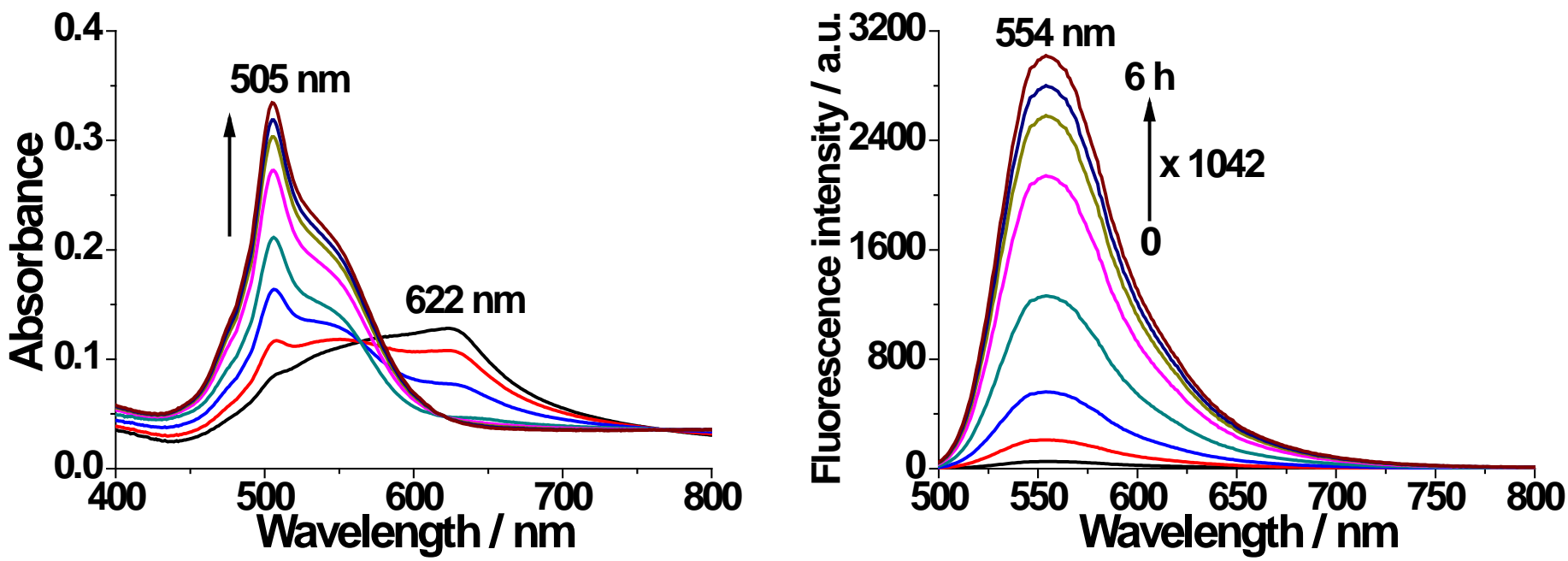

Figure S37. Stability of 2-NHS to hydrolysis. Time-dependent absorption (left) and fluorescence emission (right) spectra of 2-NHS (5 $\mu \mathrm{M})$ in PBS solution $\left(10 \mathrm{mM}, \mathrm{pH} 9.2,1 \% \mathrm{CH}_{3} \mathrm{CN}\right)$ at $25^{\circ} \mathrm{C}$. Incubation time $=0,0.5,1,2$, 3, 4, 5, 6 hours. 


\section{(b) Chemical stability of 2-NHS against background hydrolysis in aqueous buffer solution by HPLC analysis}

Determination of half-life ( $\left.\mathrm{t}_{1 / 2}\right)$ of hydrolysis of 2-NHS $(10 \mu \mathrm{M})$ at $\mathrm{pH} 7.4$ and 9.2

The hydrolysis rate constant $(k)$ of 2-NHS $(10 \mu \mathrm{M})$ in aqueous solution at different $\mathrm{pH}$ systems $(\mathrm{pH} 7.4$ and $\mathrm{pH}$ 9.2) containing $1 \% \mathrm{CH}_{3} \mathrm{CN}$ as a cosolvent at $25{ }^{\circ} \mathrm{C}$ was determined by HPLC analysis (Figure S40). After the indicated incubation time, a solution $(20 \mu \mathrm{L})$ of the 2-NHS was injected for analysis, and the concentrations of the hydrolysis product $\mathbf{1}$ was obtained by the integration of peak area at $3.04 \mathrm{~min}$. The rate constant $(k)$ for the conversion of 2-NHS to compound $\mathbf{1}$ was determined by fitting the chromatographic peak area at 3.04 min to the equation 3:

$$
\ln \left[\left(\mathrm{C}_{\max }-\mathrm{C}_{t}\right) / \mathrm{C}_{\max }\right]=-k_{\text {obs }} \cdot t
$$

where $C_{t}$ is the calculated concentration of $\mathbf{1}$ at each time interval $(t)$ measured and $\mathrm{C}_{\max }$ is the concentration of $\mathbf{1}$ $(10 \mu \mathrm{M}) . k_{\text {obs }}$ is the observed rate constant. Figure S38 is the kinetic curves for the hydrolysis of 2-NHS to compound $\mathbf{1}$ as a function of incubation time at $25{ }^{\circ} \mathrm{C}$ at $\mathrm{pH} 7.4$ (left) and $\mathrm{pH} 9.2$ (right). Figure S39 (right) is the pseudo first-order plot for the hydrolysis of 2-NHS at pH 7.4 (black) and pH 9.2 (blue). The negative slope of the plot provides the observed rate constant ( $k_{\mathrm{obs}}$ ) with value of $0.0112 \mathrm{~h}^{-1}$ for $\mathrm{pH} 7.4$ and $0.5939 \mathrm{~h}^{-1}$ for $\mathrm{pH} 9.2$, respectively. The hydrolysis half-life $\left(t_{1 / 2}\right)$ can be expressed as equation 4 :

$$
t_{1 / 2}=\ln 2 / k_{\mathrm{obs}}
$$

The hydrolysis half-lives of 2-NHS in each buffer solution at $25^{\circ} \mathrm{C}$ are 2.58 days for $\mathrm{pH} 7.4$ and 1.17 hours for $\mathrm{pH}$ 9.2, respectively, indicating that 2-NHS is highly stable in neutral solution (pH 7.4). 

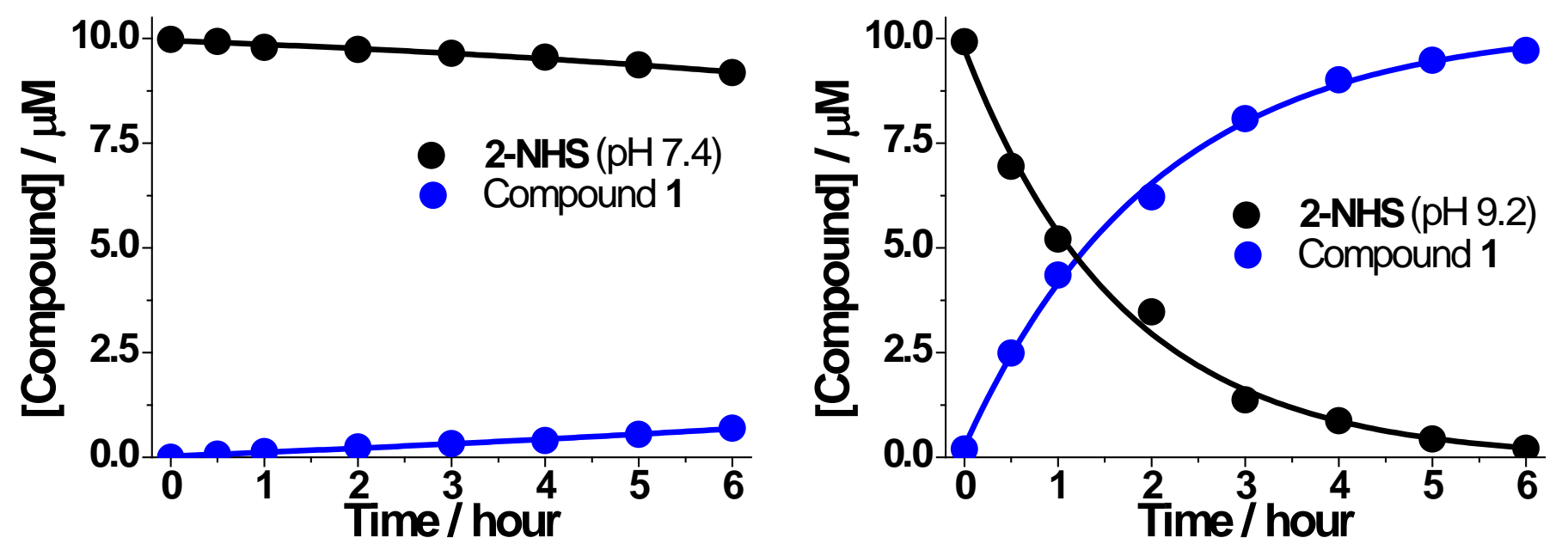

Figure S38. Kinetic curves of the hydrolysis of 2-NHS (black) and the formation of compound $\mathbf{1}$ (blue) at $\mathrm{pH} 7.4$ (left) and pH 9.2 (right) buffer systems $\left(10 \mathrm{mM}, 1 \% \mathrm{CH}_{3} \mathrm{CN}\right)$ at $25{ }^{\circ} \mathrm{C}$. Incubation time $=0,0.5,1,2,3,4,5,6$ hours.
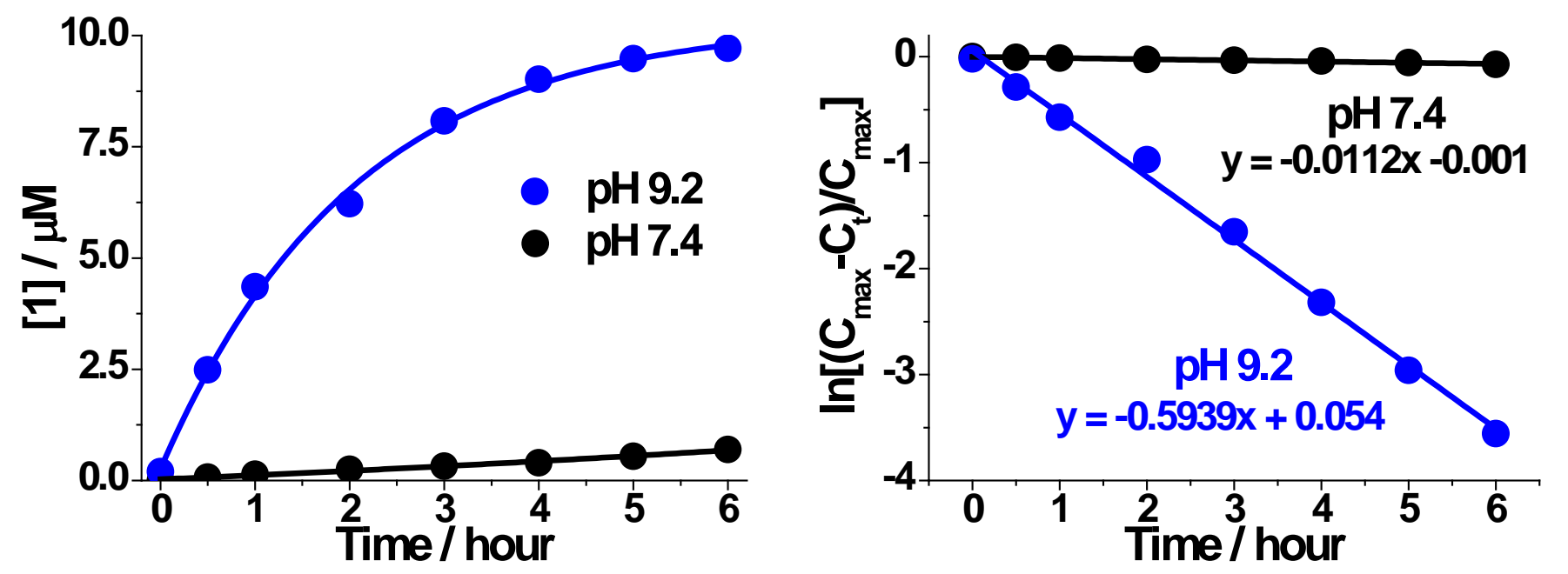

Figure S39. (left) Kinetic curves of the formation of compound 1 at $\mathrm{pH} 7.4$ (black) and pH 9.2 (blue) buffer systems $\left(10 \mathrm{mM}, 1 \% \mathrm{CH}_{3} \mathrm{CN}\right)$ at $25^{\circ} \mathrm{C}$. Incubation time $=0,0.5,1,2,3,4,5,6$ hours. (right) Pseudo first-order kinetic plot of the hydrolysis of 2-NHS $(10 \mu \mathrm{M})$ at different pH systems (black: pH 7.4, blue: pH 9.2) at $25{ }^{\circ} \mathrm{C}$. 
pH 7.4

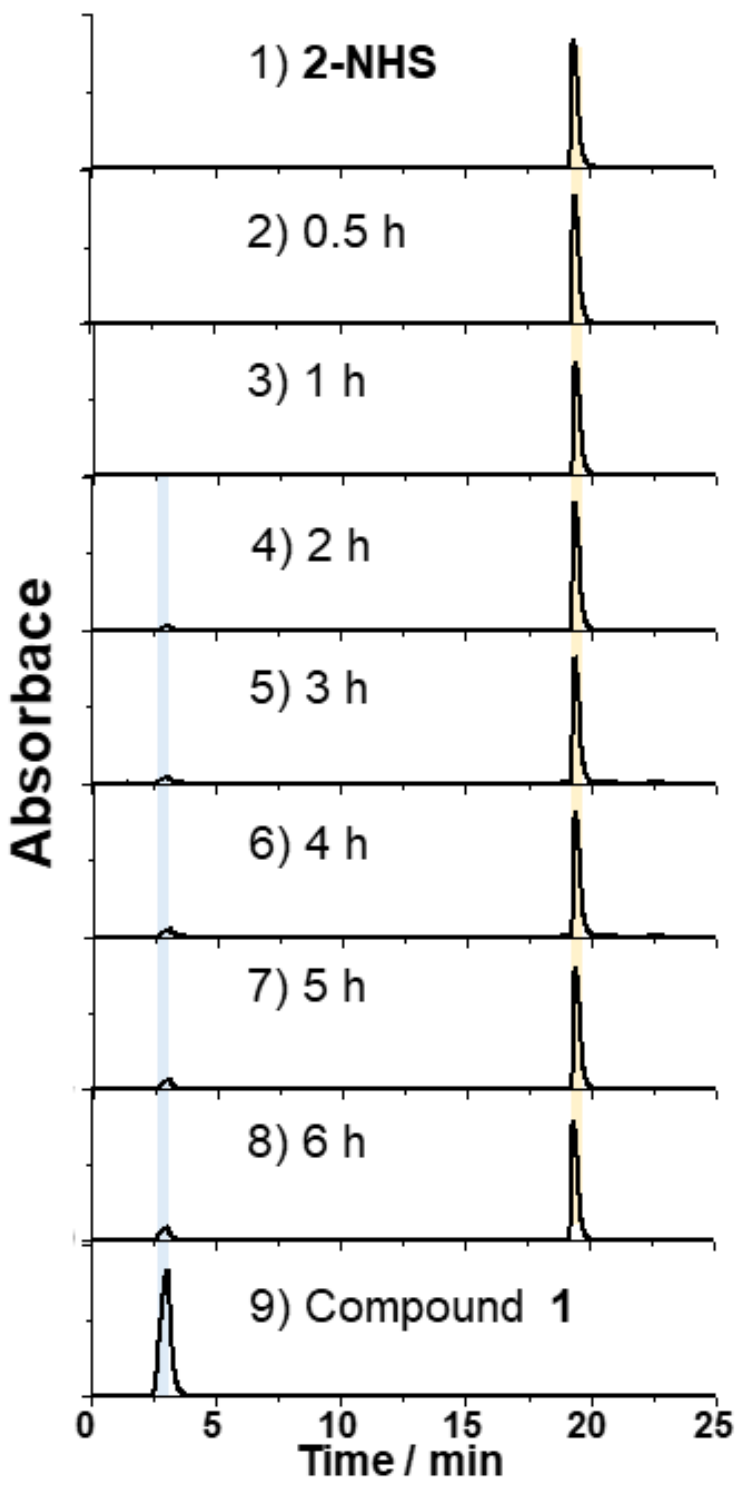

pH 9.2

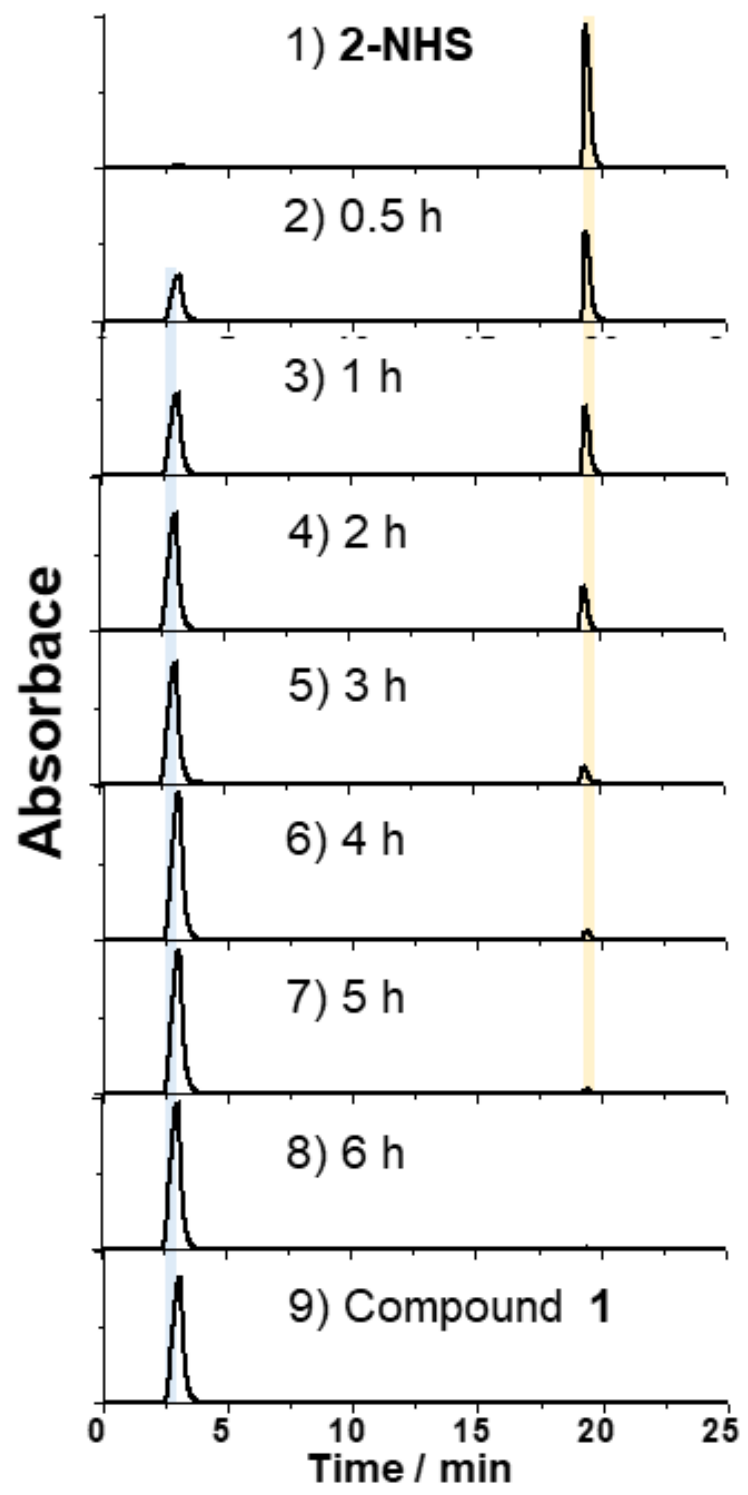

Figure S40. HPLC monitoring of 2-NHS in aqueous buffer solution (left: $\mathrm{pH} 7.4$, right: $\mathrm{pH} 9.2$ ) at $25{ }^{\circ} \mathrm{C}$. All chromatograms were obtained immediately (1), 0.5 hour (2), 1 hour (3), 2 hours (4), 3 hours (5), 4 hours (6), 5 hours (7), and 6 hours (8) after the addition of 2-NHS to each solution (left, $\mathrm{pH}$ 7.4; right, $\mathrm{pH}$ 9.2); HPLC chromatogram from authentic compound $\mathbf{1}$ is shown in (9). The samples were analyzed by HPLC with a linear gradient elution (from 10 to $100 \% \mathrm{~B}$, A: deionized water, B: $\mathrm{CH}_{3} \mathrm{CN}$, flow rate $1 \mathrm{~mL} / \mathrm{min}$, UV-Vis: $500 \mathrm{~nm}$ ). [2NHS $]=[1]=10 \mu \mathrm{M}$. 

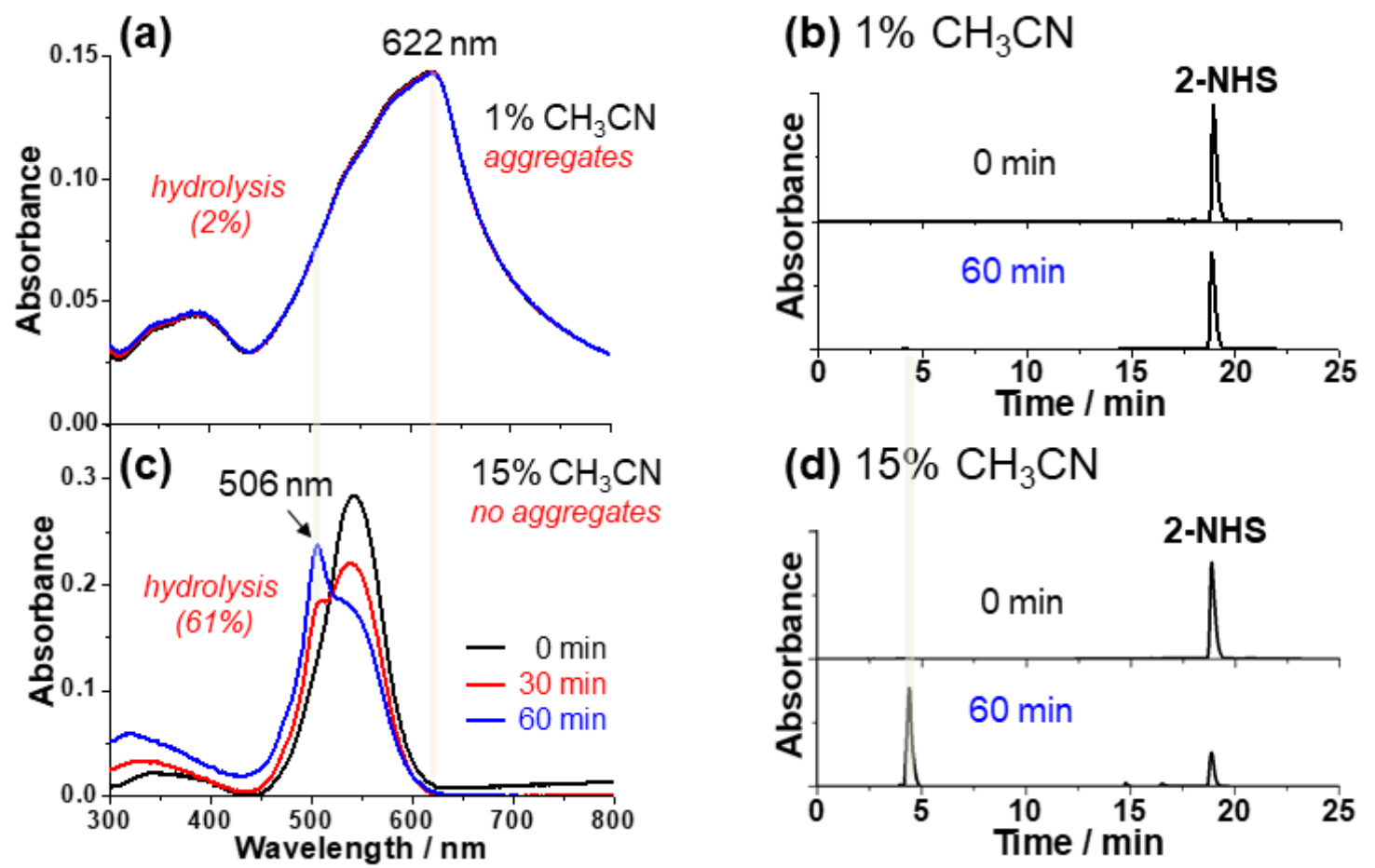

Figure S41. Monitoring of absorption spectra of 2-NHS in PBS solution (10 mM, pH 7.4, $\left.25^{\circ} \mathrm{C}\right)$ containing $1 \%$ (A, aggregates) and 15\% (C, no aggregates) $\mathrm{CH}_{3} \mathrm{CN}$, for 1 hour. The formation of hydrolyzed product 1 after 1 hour incubation was quantified by HPLC analysis (2-NHS in 1\% (B) and 15\% (D) $\mathrm{CH}_{3} \mathrm{CN}$ ). [2-NHS] = $5 \mu \mathrm{M}$.

(d) Chemical stability of meso-amide BODIPY $3 b$ in aqueous buffer solution (pH 7.4 and pH 9.2)
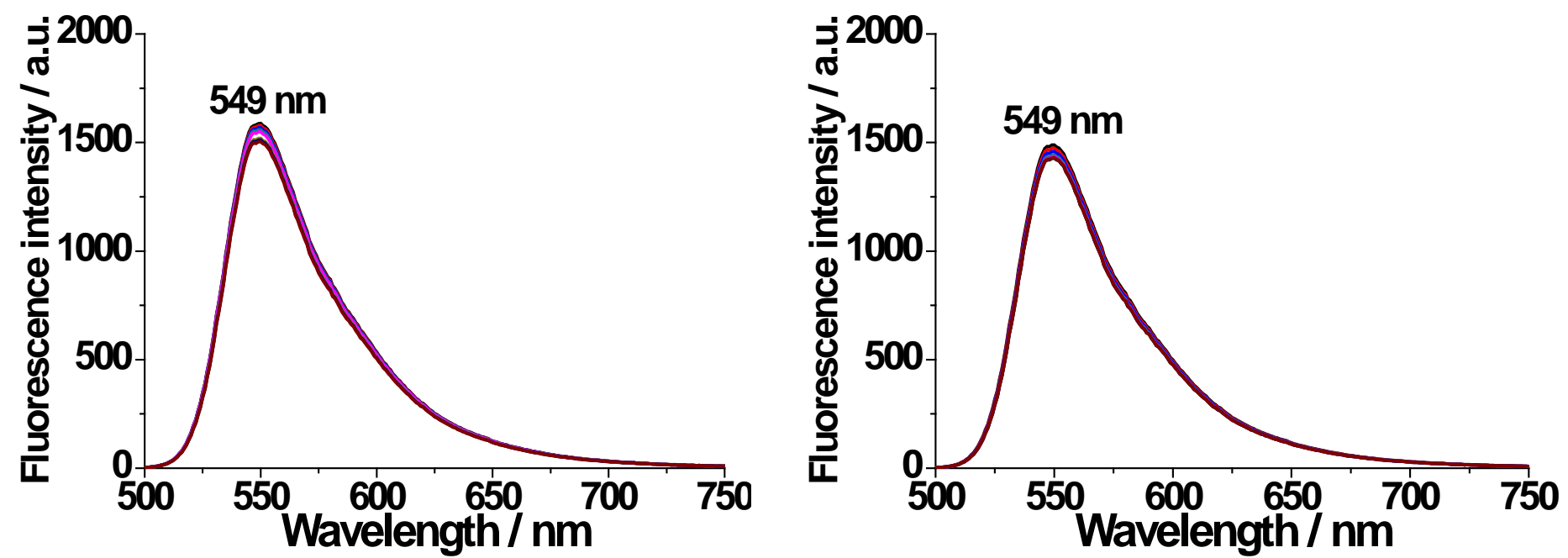

Figure S42. Stability of $\mathbf{3 b}$ to hydrolysis. Time-dependent fluorescence emission spectra of $\mathbf{3 b}$ in different $\mathrm{pH}$ buffer (left: $\mathrm{pH} 7.4$, right: $\mathrm{pH} 9.2$ ) systems containing $1 \% \mathrm{CH}_{3} \mathrm{CN}$ as a cosolvent at $25^{\circ} \mathrm{C}$. Incubation time $=0$, $0.5,1,2,3,4,5,6$ hours. Excited at $470 \mathrm{~nm}$. [3b] $=5 \mu \mathrm{M}$. 

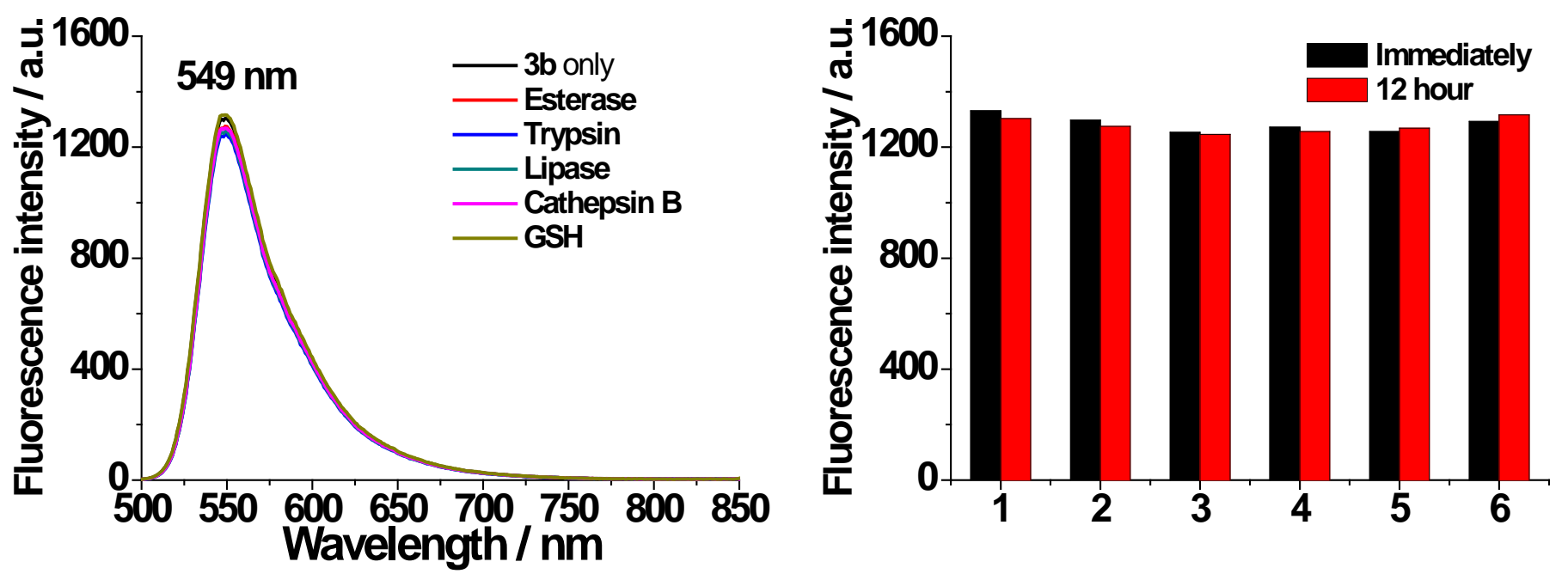

Figure S43. Fluorescence emission spectra (left) and relative fluorescence intensity (right) of $\mathbf{3 b}$ in the presence of various biomolecules in PBS solution (10 mM, $\left.\mathrm{pH} 7.4,1 \% \mathrm{CH}_{3} \mathrm{CN}\right)$ at $37{ }^{\circ} \mathrm{C}$ : (1) $3 \mathbf{b}$ only as a control, (2) esterase (1 U/mL), (3) trypsin (1 mg/mL), (4) lipase (1 mg/mL), (5) cathepsin B (1 $\mathrm{gg} / \mathrm{mL})$, (6) GSH (5 mM). The emission spectra were obtained 12 hours after the addition of $\mathbf{3 b}$ to each solution, and fluorescence intensity at $549 \mathrm{~nm}$ was measured. Excited at $470 \mathrm{~nm}$. [3b] $=5 \mu \mathrm{M}$. 


\section{Fluorogenic Detection of Proteins on Electrophoresis Gels}

\section{(a) Pre-staining with 2-NHS}

$1 \mathrm{~mL}$ of BSA (10 mg, $15 \mu \mathrm{M})$ was diluted with PBS (10 mM, pH 7.4) to give final concentrations ranging of $0.004 \mathrm{mg} / \mathrm{mL}$ to $0.4 \mathrm{mg} / \mathrm{mL}$. $10 \mu \mathrm{L}$ of 2-NHS (stock: $1 \mathrm{mM}, 10 \mu \mathrm{M})$ was incubated with BSA $(0.004 \sim 0.4 \mathrm{mg} / \mathrm{mL}$, $1 \mathrm{~mL}$ ) at room temperature for $30 \mathrm{~min}$. After incubation, $5 \mu \mathrm{L}$ (for example: $0.4 \mathrm{mg} / \mathrm{mL} \rightarrow 2 \mu \mathrm{g} ; 0.004 \mathrm{mg} / \mathrm{mL}$ $\rightarrow 0.02 \mu \mathrm{g}$ ) of mixture was mixed with $5 \mu \mathrm{L}$ sample buffer (Invitrogen, $4 \times$ ) containing $141 \mathrm{mM}$ Tris base, 106 mM Tris HCl, 2\% LDS, 10\% glycerol, 0.51 mM EDTA, 0.22 mM SERVA Blue G, 0.175 mM Phenol Red. $10 \mu \mathrm{L}$ solution of mixture was loaded on the gel lanes (final amounts: 0.01, 0.05, 0.1, 0.25, 0.5, $1 \mu \mathrm{g} / \mathrm{lane}$ ). $50 \mathrm{~mL}$ of the running buffer (Formedium, 20×) containing $50 \mathrm{mM}$ Tris, $50 \mathrm{mM}$ MOPS, $3.47 \mathrm{mM}$ SDS, $1 \mathrm{mM}$ EDTA was diluted with $950 \mathrm{~mL}$ of water. Electrophoresis was performed at $80 \mathrm{~V}$ for $30 \mathrm{~min}$. Photographs were taken immediately after staining without washing step. Fluorescence images were obtained under 365 nm hand-held UV lamp. To visualize the loaded BSA, gel was immersed into $50 \mathrm{~mL}$ of Coomassie Brilliant Blue R250 solution for $3 \mathrm{~h}$, and washed by immersing into $100 \mathrm{~mL}$ of de-staining solution (water:MeOH:AcOH = 6:3:1, v:v\%) at room temperature for $12 \mathrm{~h}$.

\section{(b) Post-staining with 2-NHS}

$1 \mathrm{~mL}$ of BSA (10 mg, $15 \mu \mathrm{M})$ was diluted with PBS (10 mM, pH 7.4) to give final concentrations ranging of $0.004 \mathrm{mg} / \mathrm{mL}$ to $0.4 \mathrm{mg} / \mathrm{mL}$. $5 \mu \mathrm{L}$ of BSA solution (for example: $0.4 \mathrm{mg} / \mathrm{mL} \rightarrow 2 \mu \mathrm{g} ; 0.004 \mathrm{mg} / \mathrm{mL} \rightarrow 0.02 \mu \mathrm{g}$ ) was mixed with $5 \mu \mathrm{L}$ sample buffer. $10 \mu \mathrm{L}$ of mixture solution was loaded on the gel lanes (final amounts: 0.01 , 0.05, 0.1, 0.25, 0.5, $1 \mu \mathrm{g} / \mathrm{lane}$ ). Electrophoresis was performed at $80 \mathrm{~V}$ for $30 \mathrm{~min}$. After SDS-PAGE, gel was immersed into $50 \mathrm{~mL}$ of 2-NHS solution (final concentrations: $100 \mu \mathrm{M})$ dissolved in PBS (10 mM, pH 7.4, 50\% $\mathrm{CH}_{3} \mathrm{CN}$ ) at room temperature for $30 \mathrm{~min}$. Photographs were taken immediately after staining without washing step.

\section{(c) Preparation of the triply 2-labeled BSA for MS analyses}

The 2-NHS/BSA conjugate was prepared by incubating 2-NHS (5 equiv) with BSA (1 mg) for 30 min in PBS buffer $\left(1 \mathrm{~mL}\right.$ [15 $\mu \mathrm{M}$ in BSA], $10 \mathrm{mM}$ PBS, $\left.\mathrm{pH} 7.4,1 \% \mathrm{CH}_{3} \mathrm{CN}\right)$ at $25^{\circ} \mathrm{C}$. The entire sample was lyophilized following the incubation to yield the solid 2-labeled protein, which could be further purified by gel filtration or SDS-PAGE, depending on the application. The $D / P$ ratio was determined to be 3.68 by the absorption spectra of 2-NHS/BSA conjugate. 

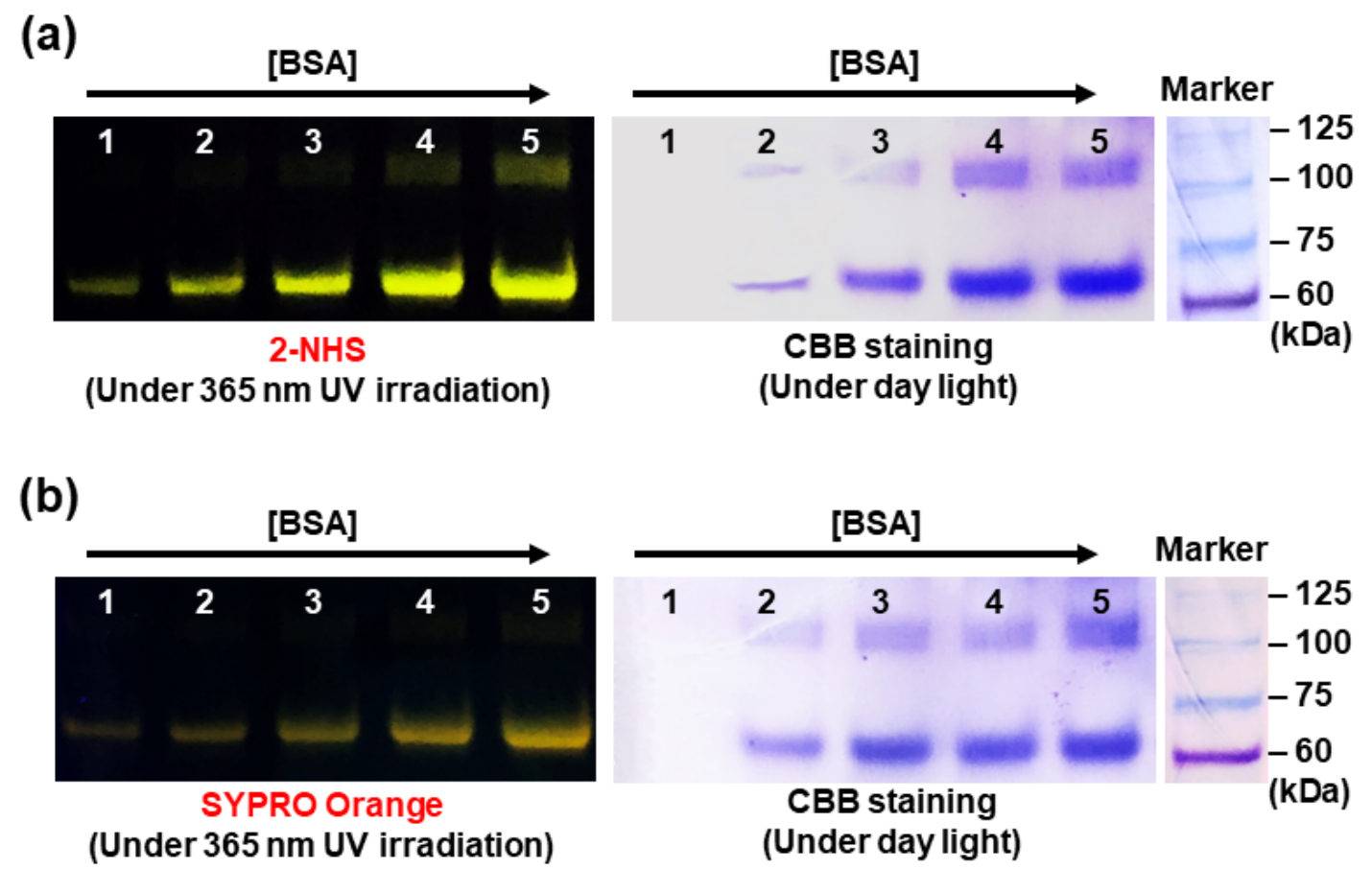

Figure S44. SDS-PAGE gel electrophoresis of BSA using (a) 2-NHS and (b) SYPRO ${ }^{\mathrm{TM}}$ Orange Protein Gel Stain. SDS-PAGE fluorescence image (left) of BSA at different amounts (lanes 1-5: 0.01, 0.05, 0.1, 0.25, $0.5 \mu \mathrm{g}$ ) poststained with 2-NHS (a) and SYPRO ${ }^{\mathrm{TM}}$ Orange (b), respectively, and images of the same gel re-stained with CBB R250 (right). Fluorescent gel images were obtained without a washing step, under UV (365 nm) irradiation. Protein size markers are shown on Marker lane. 
(d) MALDI-TOF MS analysis of BSA and 2-NHS/BSA conjugate
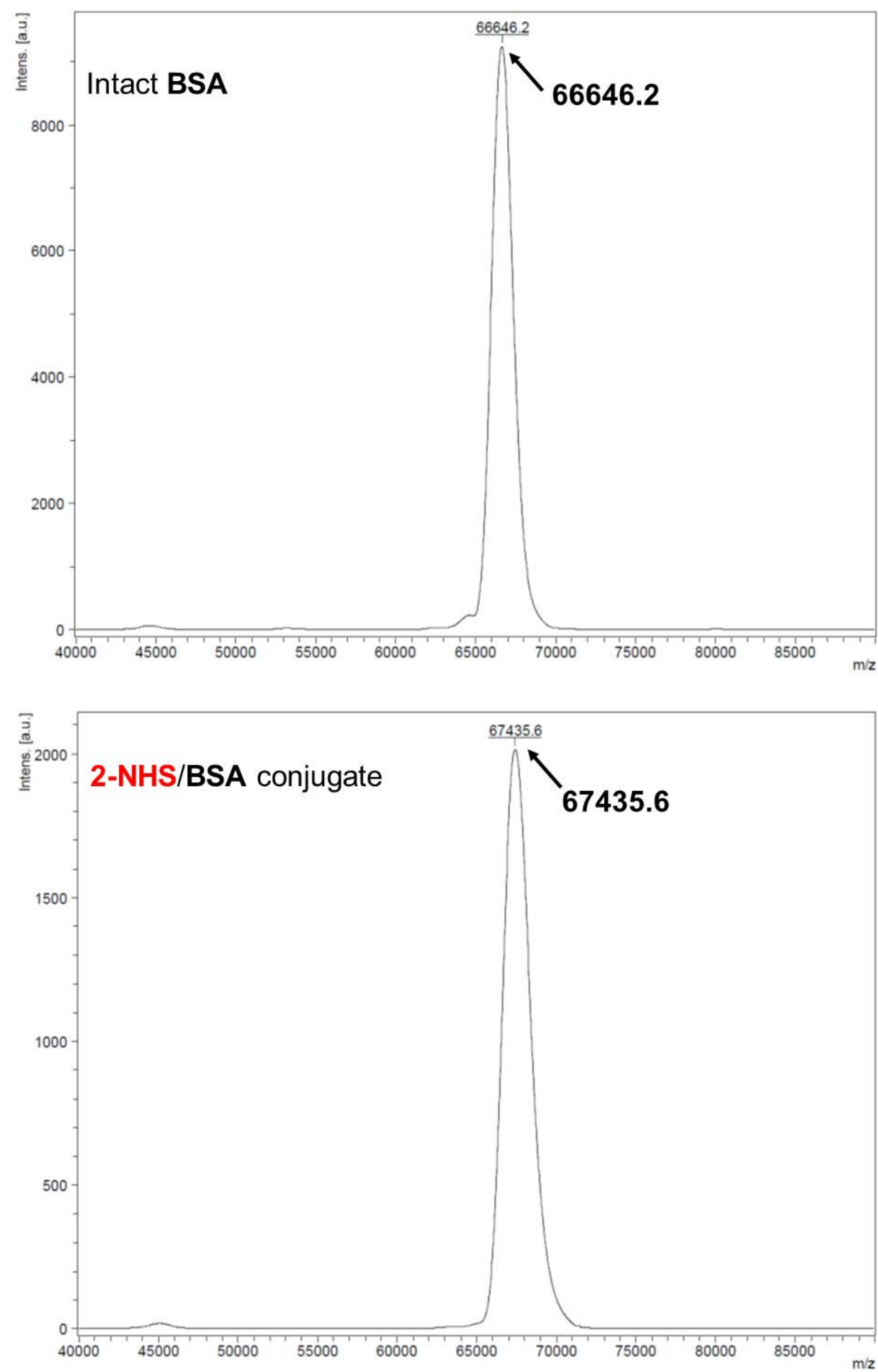

Figure S45. MALDI-TOF MS spectra of native BSA (top) and 2-NHS/BSA conjugate (bottom). D/P ratio was determined to be 3.68 by the absorption spectra of 2-NHS/BSA conjugate, 3 dye labels were found by MALDITOF MS spectra (ammonium buffer was used). The conjugate signal at $67435.6 \mathrm{~m} / \mathrm{z}$ corresponds to [BSA - [3 $\times(2$ $\left.\left.\left.\mathrm{H}^{+}\right)\right]+[3 \times(2)]+\left[3 \times\left(\mathrm{NH}_{4}^{+}\right)\right]\right]$, in which the 3,5-dimethyl-8-acylBODIPY fragment 2 is $247 \mathrm{~g} / \mathrm{mol}$. 
(e) LC-MS/MS analysis of tryptic peptides obtained from the in-gel digestion of either BSA or the 2-NHS/BSA conjugate

\section{Methods and procedure for LC-MS/MS analysis}

After staining with colloidal Coomassie blue, the protein gels were sliced and submitted to an in-gel tryptic digestion, as described by Shevchenko and co-workers. ${ }^{7}$ The resulting tryptic digestion peptides were analyzed by LC-MS/MS. All mass analyses were performed on a Q Exactive Plus Orbitrap mass spectrometer (Thermo Fisher Scientific, MA, USA) equipped with a nanoelectrospray ion source. The peptide mixture was separated on a C18 reverse-phase HPLC column $(500 \mathrm{~mm} \times 75 \mu \mathrm{m}$ ID) using an acetonitrile $/ 0.1 \%$ formic acid gradient from 15 to $45 \%$ for $60 \mathrm{~min}$ at a flow rate of $300 \mathrm{~nL} / \mathrm{min}$. For MS/MS analysis, the precursor ion scan MS spectra $(\mathrm{m} / \mathrm{z}$ $400 \sim 2000$ ) were acquired in the Orbitrap at a resolution of 70,000 at $\mathrm{m} / \mathrm{z} 400$ with an internal lock mass. The 20 ions responsible for the most intense signals were isolated and fragmented by high-energy collision induced dissociation (HCD).

\section{LC-MS/MS data processing}

All MS/MS samples were analyzed using the Sequest Sorcerer platform (Sagen-N Research, San Jose, CA). Sequest was set up to search the BSA protein sequence database (245 entries), which includes frequently observed contaminants, assuming the digestion enzyme trypsin. Sequest searches were performed with a fragment ion mass tolerance of $0.60 \mathrm{Da}$ and a parent ion tolerance of 10.0 PPM. Carbamidomethyl functionalization of cysteine residues was specified in Sequest as a fixed modification. Oxidation of methionine and labeling of lysine and arginine by 2 were specified in Sequest as variable modifications. Scaffold (Version 4.10.0, Proteome Software Inc., Portland, OR) was used to validate MS/MS-based peptide and protein identifications. Peptide identifications were accepted if they satisfied a greater than $99.0 \%$ probability threshold, in order to achieve a false discovery rate (FDR) of less than $1.0 \%$ by the Scaffold Local FDR algorithm. Protein identifications were accepted if they satisfied a greater than $99.0 \%$ probability threshold, in order to achieve a FDR of less than $1.0 \%$, and contained at least five identified peptides. Protein probabilities were assigned by the ProteinProphet algorithm. ${ }^{8}$ Proteins that contained similar peptides and could not be differentiated based on MS/MS analysis alone were grouped to satisfy the principles of parsimony.

Table S3. Summary of LC-MS/MS analysis of tryptic peptides obtained from the in-gel digestion of either 2labeled BSA or native BSA.

\begin{tabular}{ccccc}
\hline & $\begin{array}{c}\text { Exclusive unique } \\
\text { peptides }\end{array}$ & $\begin{array}{c}\text { Sequence } \\
\text { coverage (\%) }\end{array}$ & $\begin{array}{c}\text { 2-Labeled } \\
\text { peptides }\end{array}$ & Amino acid sequence* \\
\hline 2-Labeled BSA & 85 & 93 & 3 & $\begin{array}{l}\text { (R) LRCASIQK (F) } \\
\text { (R) ALKAWSVAR (L) } \\
\text { (K) KQTALVELLK (H) }\end{array}$ \\
Native BSA & 84 & 91 & 0 & - \\
\hline
\end{tabular}

*Residues in red were identified as having been labeled using 2-NHS. 
(a) ALBU_BOVIN $(100 \%), 69,294.2 \mathrm{Da}$

Serum albumin $O S=B$ os taurus $G N=A L B P E=1 S V=4$

85 exclusive unique peptides, 155 exclusive unique spectra, 1293 total spectra, 564/607 amino acids (93\% coverage)

$M K W V T F$ I L L F S Q Y L Q Q C P F V A S L R E T Y G D K A D E K K F W G K L L P K I E T M R E F V E V T K L V T D C C D K P L L EK S G S F L Y E Y S R R K H L V D E P Q N L R S L G K V G T R C TE S L V N R R P C A L V E L L K H K P S T Q T A L A

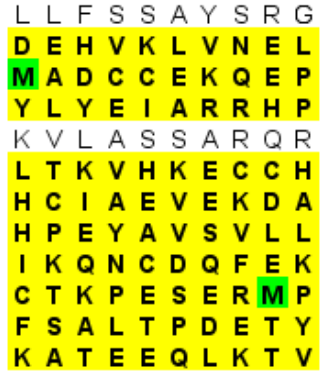

VFRR D T H K S E TE F A K T C V A D E R N E C F L S H K YF Y A P E L L Y Y L R C A S I Q K F G G D L L E C A D D R I PEN L P P L T A R L A K E Y E A T L L G E Y G $F$ Q N A L C TEDYLSL I L V P K A F DEKLF ME N F V A F V D K
I A HRF K D L GE E S H A G C EK S L D D S P D L P K LK A N K Y N G V F Q E E R A L K A W S V A A D L AKY I C D N D F A E D D V C K E E C C AKD D P H I V R Y TR K V P Q N R L C V L H E K T T F H A D I C T L P C C A A D DKEAC
EHF K G L V L I A H T L F G D E L C K PDPNTLCDEF C C Q A E D K G A C $R L S Q K F$ P K AE QD T I S S K L K E N Y Q E A K D A F L A C Y S T V F D K L V S T P T L V E V S $P V S E K V T K C$ C D T E K Q I K KQT F A V E G P K L V V

(b) ALBU_BOVIN (100\%), 69,294.2 Da

Serum albumin $O S=B o s$ taurus $G N=A L B P E=1$ SV=4

84 exclusive unique peptides, 150 exclusive unique spectra, 1293 total spectra, 554/607 amino acids (91\% coverage)

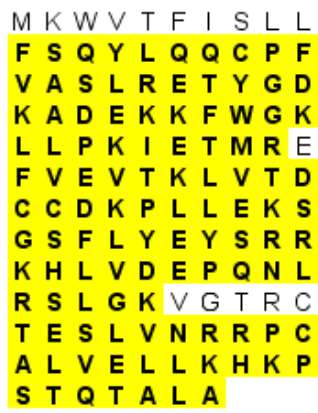

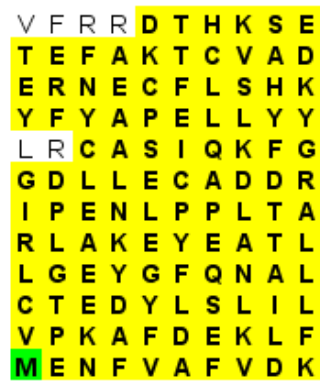

I A HRF K D L G E E S H A G C EK S L D D S P D L P K L K A N K Y N G V F Q E E R A L K A W S V A A D L A K Y I C D N D F A E D K D V C K E E C C A K D D P H I V R Y T R K V P Q N R L C V L H E K T T F H A D I C T L P C C A A D DKEAC

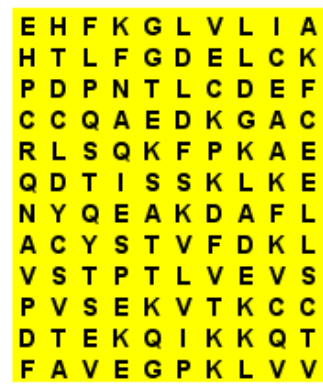

Figure S46. LC-MS/MS analysis of the tryptic peptides obtained from the in-gel digestion of either 2-labeled BSA (a) or native BSA (b). The 84 exclusive unique peptides found for the 2-labeled BSA (93\% coverage; a) and 83 exclusive unique peptides found for native BSA (91\% coverage; b) are highlighted in yellow. Residues highlighted in green indicate modified sites: oxidized methionine (M), and the three sites labeled with 2 (i.e., R198, K211 and K524). The three 2-labeled tryptic peptides identified in the LC-MS/MS experiment are shown within the red rectangles. 
(a) Response of 2-NHS toward BSA
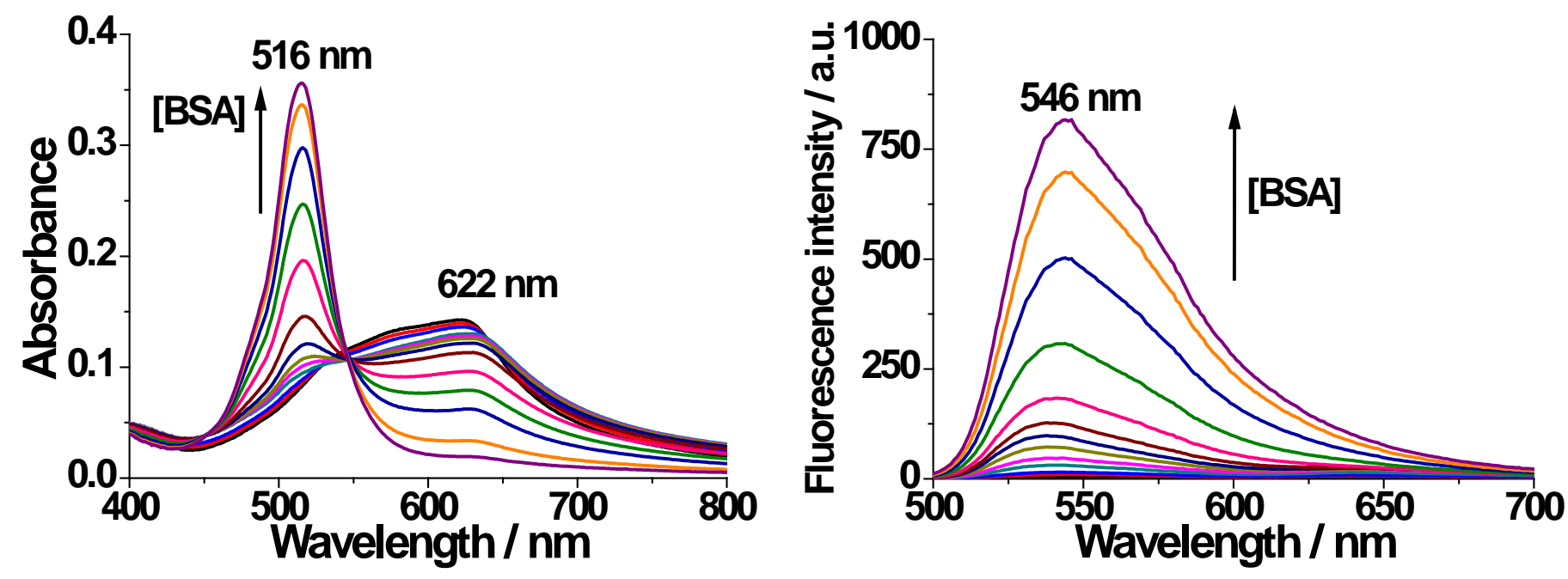

Figure S47. Absorption (left) and fluorescence emission (right) spectra of 2-NHS (5 $\mu \mathrm{M})$ upon addition of BSA at different concentrations $(0,0.01,0.05,0.1,0.2,0.33,0.5,0.67,1.0,1.67,2.5,3.3,5.0 \mathrm{mg} / \mathrm{mL})$ in PBS solution $\left(10 \mathrm{mM}, \mathrm{pH} 7.4,1 \% \mathrm{CH}_{3} \mathrm{CN}\right)$ at $25^{\circ} \mathrm{C}$. All spectra were obtained 5 min after the addition of 2-NHS to each solution. Excited at $470 \mathrm{~nm}$.

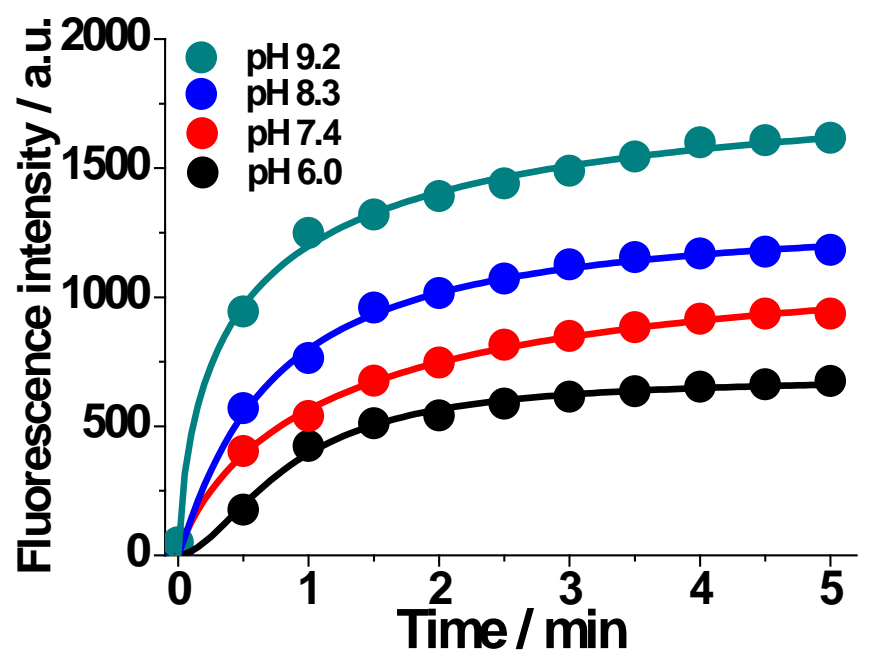

Figure S48. Time-dependent fluorescence intensity of 2-NHS $(5 \mu \mathrm{M})$ upon incubation with BSA $(10 \mathrm{mg} / \mathrm{mL})$ in various $\mathrm{pH}$ buffer systems $(10 \mathrm{mM}, \mathrm{pH} 6.0-9.2)$ containing $1 \% \mathrm{CH}_{3} \mathrm{CN}$ as a cosolvent at $25{ }^{\circ} \mathrm{C}$. The emission spectra were obtained every $30 \mathrm{sec}(0-5 \mathrm{~min})$, and fluorescence intensity at $546 \mathrm{~nm}$ was measured. Excited at 470 nm. 

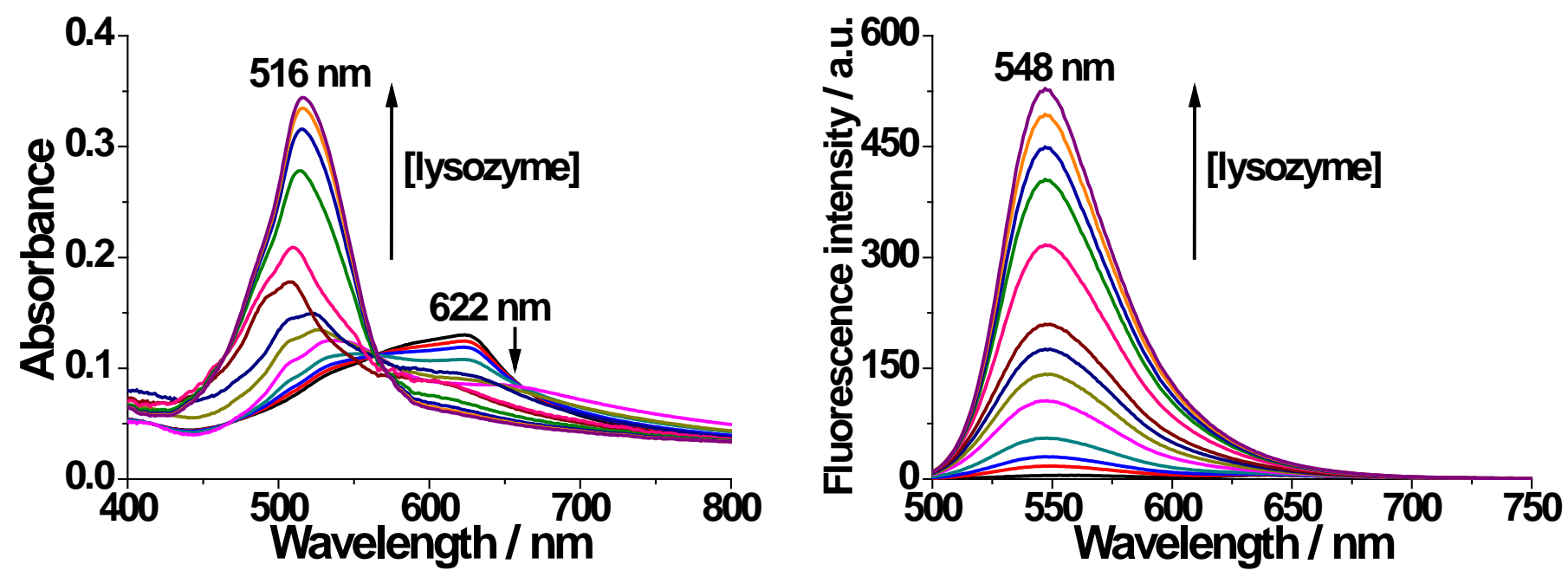

Figure S49. Absorption (left) and fluorescence emission (right) spectra of 2-NHS (5 $\mu \mathrm{M})$ upon addition of lysozyme at different concentrations $(0,0.01,0.05,0.1,0.2,0.33,0.5,0.67,1.0,1.67,2.5,3.3,5.0 \mathrm{mg} / \mathrm{mL}) \mathrm{in}$ PBS solution (10 mM, pH 7.4, 1\% $\left.\mathrm{CH}_{3} \mathrm{CN}\right)$ at $25^{\circ} \mathrm{C}$. All spectra were obtained 5 min after the addition of 2-NHS to each solution. Excited at $470 \mathrm{~nm}$.

(c) Response of 2-NHS toward IgG
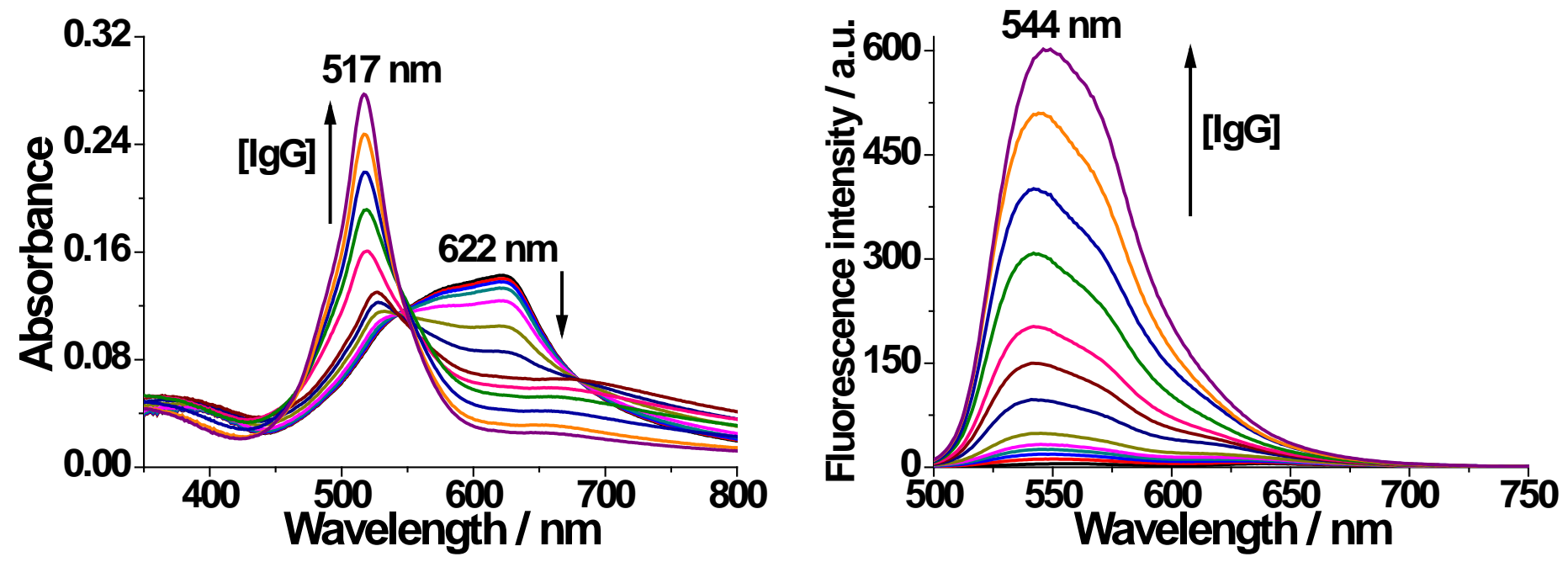

Figure S50. Absorption (left) and fluorescence emission (right) spectra of 2-NHS (5 $\mu \mathrm{M})$ upon addition of IgG at different concentrations (0, 0.01, 0.05, 0.1, 0.2, 0.33, 0.5, 0.67, 1.0, 1.67, 2.5, 3.3, $5.0 \mathrm{mg} / \mathrm{mL})$ in PBS solution $\left(10 \mathrm{mM}, \mathrm{pH} 7.4,1 \% \mathrm{CH}_{3} \mathrm{CN}\right)$ at $25^{\circ} \mathrm{C}$. All spectra were obtained $5 \mathrm{~min}$ after the addition of 2-NHS to each solution. Excited at $470 \mathrm{~nm}$. 


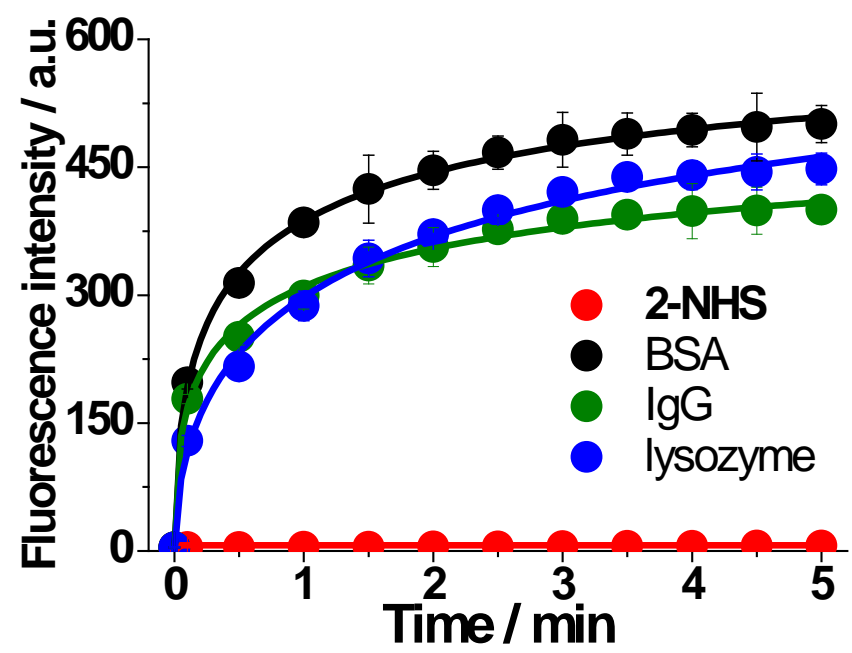

Figure S51. Time-dependent fluorescence intensity of 2-NHS $(5 \mu \mathrm{M})$ upon incubation with different proteins (red: 2-NHS only; black: BSA; green: IgG; blue: lysozyme) in PBS solution (10 mM, pH 7.4, 1\% $\left.\mathrm{CH}_{3} \mathrm{CN}\right)$ at 25 ${ }^{\circ} \mathrm{C}$. The emission spectra were obtained every $30 \mathrm{sec}(0-5 \mathrm{~min})$, and the fluorescence intensities at green emission region ( $\lambda_{\mathrm{em}}=546 \mathrm{~nm}$ for BSA, $544 \mathrm{~nm}$ for IgG, $548 \mathrm{~nm}$ for lysozyme) were recorded. Excited at $470 \mathrm{~nm}$. [protein] $=2.5 \mathrm{mg} / \mathrm{mL}$.
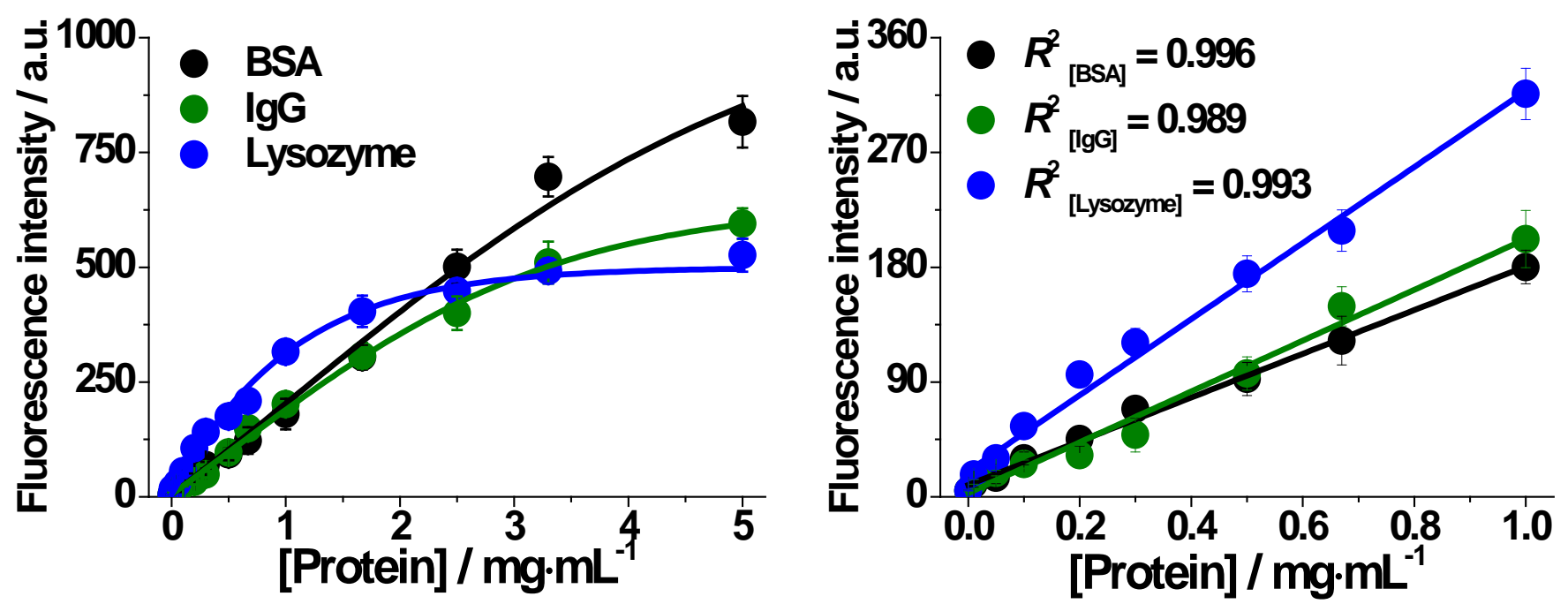

Figure S52. Relative fluorescence intensities at green emission region vs. the amounts of proteins (left: 0-5 $\mathrm{mg} / \mathrm{mL}$, right: $0-1 \mathrm{mg} / \mathrm{mL}$ ) in PBS solution (10 mM, pH 7.4, $\left.1 \% \mathrm{CH}_{3} \mathrm{CN}\right)$ at $25^{\circ} \mathrm{C}$. The spectra were obtained 5 min after the addition of 2-NHS (5 $\mu \mathrm{M})$ to each solution, and the fluorescence intensities at green emission region (546 nm for BSA, $544 \mathrm{~nm}$ for IgG, $548 \mathrm{~nm}$ for lysozyme) were recorded. Excited at $470 \mathrm{~nm}$. 

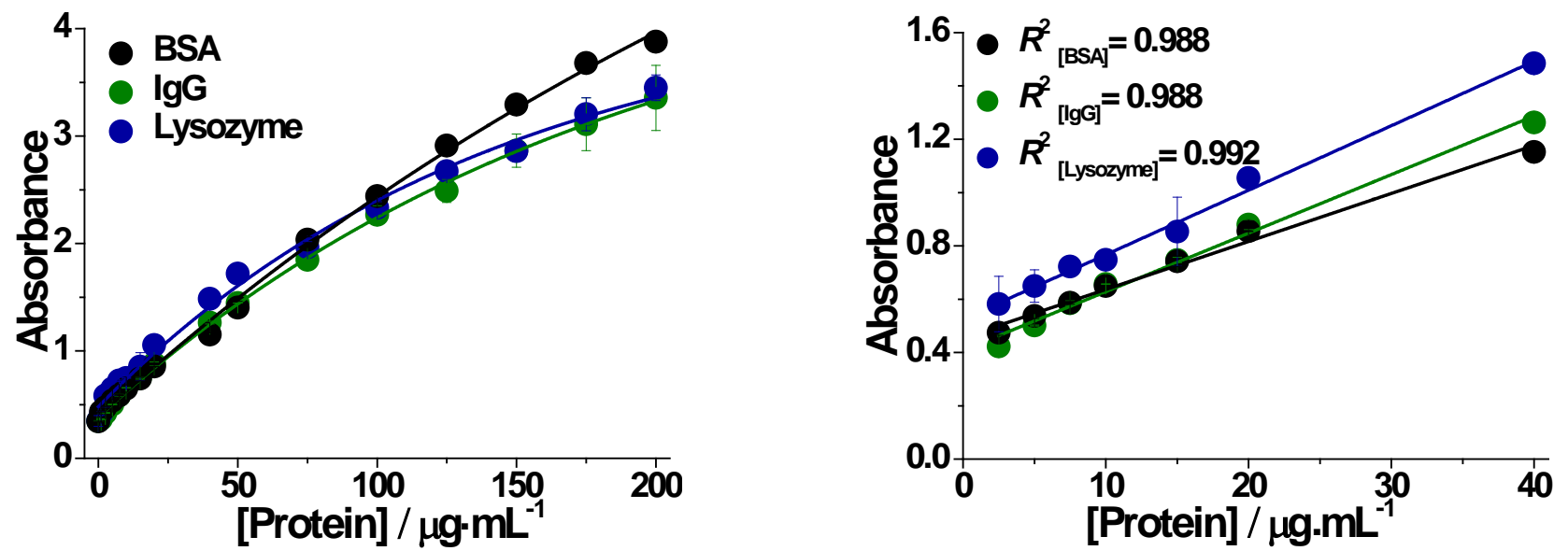

Figure S53. Micro BCA ${ }^{\mathrm{TM}}$ Protein Assay. Absorbance at $562 \mathrm{~nm}$ of BCA as a function of the amounts of proteins (black: BSA; green: IgG; blue: lysozyme) left: 0-200 $\mu \mathrm{g} / \mathrm{mL}$; right: $2.5-40 \mu \mathrm{g} / \mathrm{mL}$. LODs for protein determination based on the absorbance at $562 \mathrm{~nm}$ using the most commonly used reagent, BCA (Bicinchoninic Acid) protein assay kit was $0.37 \mu \mathrm{g} / \mathrm{mL}$ (BSA), $0.31 \mu \mathrm{g} / \mathrm{mL}$ (IgG), $0.28 \mu \mathrm{g} / \mathrm{mL}$ (lysozyme). (2 h incubation at 37 $\left.{ }^{\circ} \mathrm{C}\right)$.

\section{(f) Comparison with the Bradford assay}
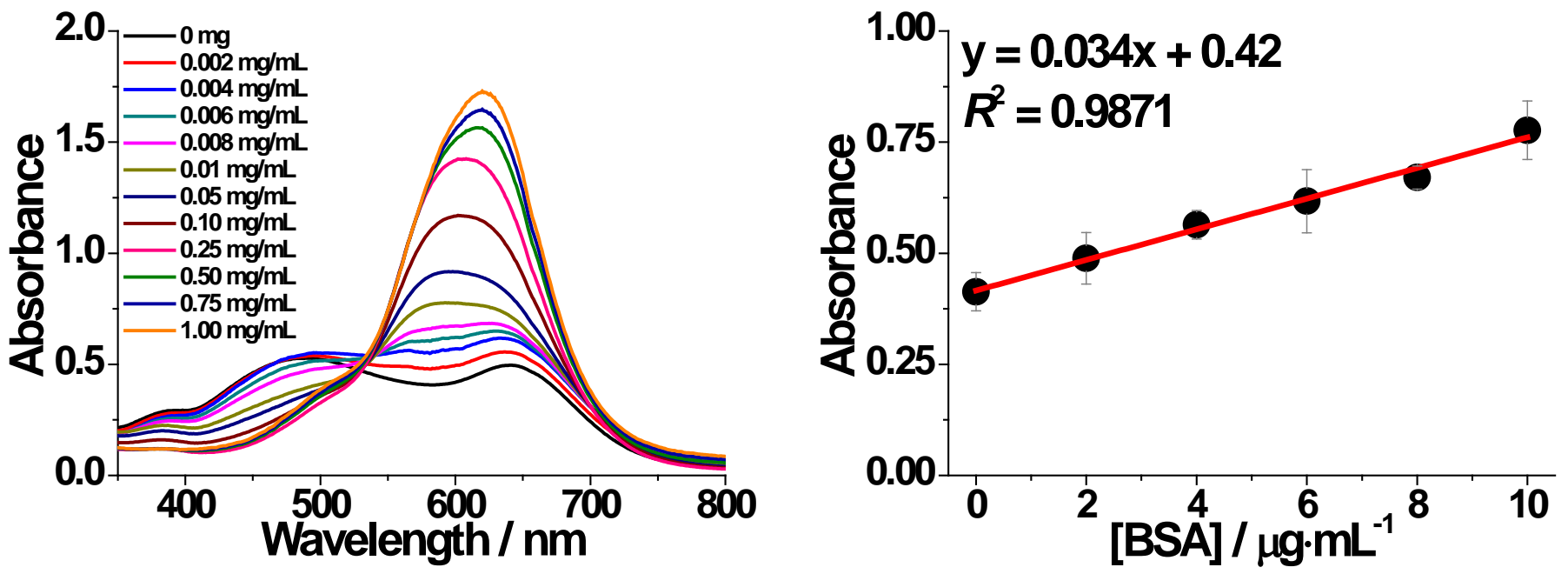

Figure S54. Bradford assay for protein quantification. (left) Absorption spectra of Coomassie Brilliant Blue G250 (CBB) dye upon incubation with BSA at different amounts (0, 0.002, 0.004, 0.006, 0.008, 0.01, 0.05, 0.1, $0.25,0.5,0.75,1 \mathrm{mg} / \mathrm{mL})$ in PBS solution $(10 \mathrm{mM}, \mathrm{pH} 7.4)$ at $25^{\circ} \mathrm{C}$. All spectra were obtained immediately after the addition of CBB to BSA solution. (right) A linear relationship between absorbance at $595 \mathrm{~nm}$ and amounts of BSA $(0-10 \mu \mathrm{g} / \mathrm{mL})$. LOD for BSA was determined to be $0.4 \mu \mathrm{g} / \mathrm{mL}$. 
Table S4: Comparison of BCA (Figure S53), Bradford (Figure S54), and 2-NHS assays (Figure 8b8d, Figure S52) for solution protein quantification.

\begin{tabular}{|c|c|c|c|}
\hline Method & Linear working range & LOD & $\begin{array}{l}\text { Reaction } \\
\text { conditions }\end{array}$ \\
\hline $\begin{array}{l}\text { Micro BCA }{ }^{\mathrm{TM}} \\
\text { Protein Assay } \\
\text { Kit }\end{array}$ & $\begin{array}{c}2.5-40 \mu \mathrm{g} / \mathrm{mL} \text { (microplate protocol)* } \\
0.5-20 \mu \mathrm{g} / \mathrm{mL} \text { (standard protocol)* }\end{array}$ & $\begin{array}{l}0.28 \mu \mathrm{g} \cdot \mathrm{mL}^{-1} \text { (lysozyme) } \\
0.31 \mu \mathrm{g} \cdot \mathrm{mL}^{-1} \text { (IgG) } \\
0.37 \mu \mathrm{g} \cdot \mathrm{mL}^{-1}(\mathrm{BSA})\end{array}$ & $\begin{array}{l}2 \mathrm{~h} \text { incubation } \\
\text { at } 37^{\circ} \mathrm{C}\end{array}$ \\
\hline $\begin{array}{l}\text { Bradford Micro } \\
\text { Assay } \\
\text { (CBB Binding) }\end{array}$ & $0-10 \mu \mathrm{g} / \mathrm{mL}$ & $0.4 \mu \mathrm{g} \cdot \mathrm{mL}^{-1}$ (BSA) & $\begin{array}{l}<5 \text { min incubation } \\
\text { at } 25^{\circ} \mathrm{C}\end{array}$ \\
\hline 2-NHS & $\begin{array}{c}0-1000 \mu \mathrm{g} / \mathrm{mL} \\
\text { (Figure } 8 \mathrm{~b}-8 \mathrm{~d} \text {, Figure 52) }\end{array}$ & $\begin{array}{l}0.08 \mu \mathrm{g} \cdot \mathrm{mL}^{-1} \text { (lysozyme) } \\
0.15 \mu \mathrm{g} \cdot \mathrm{mL}^{-1} \text { (IgG) } \\
0.18 \mu \mathrm{g} \cdot \mathrm{mL}^{-1} \text { (BSA) }\end{array}$ & $\begin{array}{l}5 \text { min incubation } \\
\text { at } 25^{\circ} \mathrm{C}\end{array}$ \\
\hline
\end{tabular}

* According to the manufacturer's guidelines. 


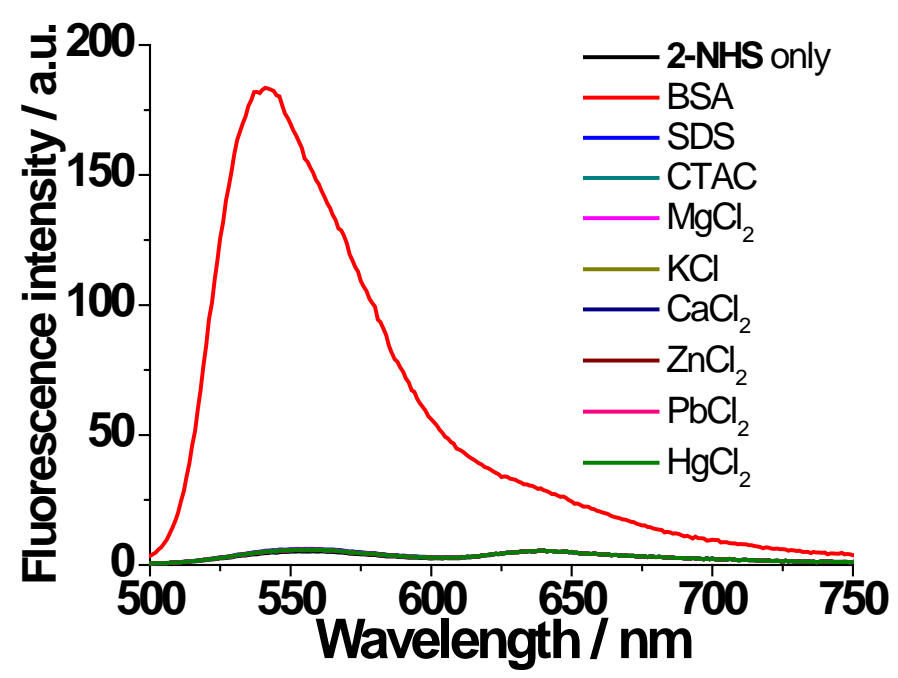

Figure S55. Fluorescence emission spectra of 2-NHS upon addition of various inorganic salts and surfactants in PBS solution (10 mM, pH 7.4, 1\% $\left.\mathrm{CH}_{3} \mathrm{CN}\right)$ at $25{ }^{\circ} \mathrm{C}$. The spectra were obtained 5 min after the addition of each analyte, and compared with the one obtained upon addition of BSA. Excited at $470 \mathrm{~nm}$. [BSA] = $1 \mathrm{mg} / \mathrm{mL}$. [Others $]=1 \mathrm{mM}$. SDS = sodium dodecyl sulfate. CTAC = cetyltrimethylammonium chloride. 
A stock solution of 2-NHS was prepared in $\mathrm{CH}_{3} \mathrm{CN}$ (concentration: $6 \mathrm{mM}$ ). A solution containing BSA (4 mg) dissolved in $2 \mathrm{~mL}$ PBS solution (10 mM, pH 7.4) were preapred to give $30 \mu \mathrm{M}$ of final concnetration. Aliquots of the dye 2-NHS stock solution (0.5, 1, 1.5, 2, 3, 4, 5, 6, 8, 10 equiv) were added to BSA solution (2 mL). The mixtures were allowed to stir for $30 \mathrm{~min}$ at room temperature to form the 2-NHS/BSA conjugate. The separion of the 2-NHS/BSA conjugate from unconjugated 2-NHS dye was performed by size exclusion chromatography (Sephadex G-50) using $10 \mathrm{mM}$ PBS buffer (pH 7.4) as a mobile phase.

Then, the absorbance spectra of purified 2-NHS/BSA conjugate were measured (Figure S56, left) to determine the labeled protein. The purified 2-NHS/BSA conjugate showed the absorbance bands at $280 \mathrm{~nm}$ and $516 \mathrm{~nm}$, which are assigned to the BSA protein and 2-NHS/BSA conjugate, respectively. Moreover, the absorbance at 516 $\mathrm{nm}$ of 2-NHS/BSA conjugate gradually increased with increasing the concentration of 2-NHS, with increasing fluorescence intensity at $546 \mathrm{~nm}$ without fluorescence quenching by energy/electron transfer from fluorophore to aromatic amino acids or dye-dye intermolecular interactions (Figure S57).

\section{Determination of the dye-to-protein ratios $(D / P)$}

Dye-to-protein $(D / P)$ value was calculated from the absorbance of the purified 2-NHS/BSA conjugate at $516 \mathrm{~nm}$ $\left(\mathrm{A}_{\text {conj }}\left(\lambda_{\max }\right)\right.$ and the absorbance of protein at $280 \mathrm{~nm}\left(\mathrm{~A}_{280}\right)$ using the following equation (5): ${ }^{9}$

$$
D / P=\mathrm{A}_{\text {conj }}(\lambda \max ) \times \varepsilon_{\mathrm{BSA}} /\left[\left(\mathrm{A}_{280}-\mathrm{CF} \times \mathrm{A}_{\text {conj }}(\lambda \max )\right) \times \varepsilon_{\text {dye }}\right]
$$

The extinction coefficient $\left(\varepsilon_{\text {dye }}=78,000 \mathrm{M}^{-1} \cdot \mathrm{cm}^{-1}\right.$ ) of the 2 -NHS/BSA conjugate is obtained from $3 \mathbf{b}$ (Table S2) and the extinction coefficient $\left(\varepsilon_{\mathrm{BSA}}=43,600 \mathrm{M}^{-1} \cdot \mathrm{cm}^{-1}\right)$ of the BSA at $280 \mathrm{~nm}$ was obtained from literature. ${ }^{10}$ Correction factor ( $\mathrm{CF}=0.076$ ) was calculated from the absorbance of $3 \mathbf{b}$ at $280 \mathrm{~nm}$ and $516 \mathrm{~nm}$. The factor 0.076 means that the absorption at $280 \mathrm{~nm}$ of $\mathbf{3 b}$ is $7.6 \%$ of its absorption at $516 \mathrm{~nm}$ (Adye). 

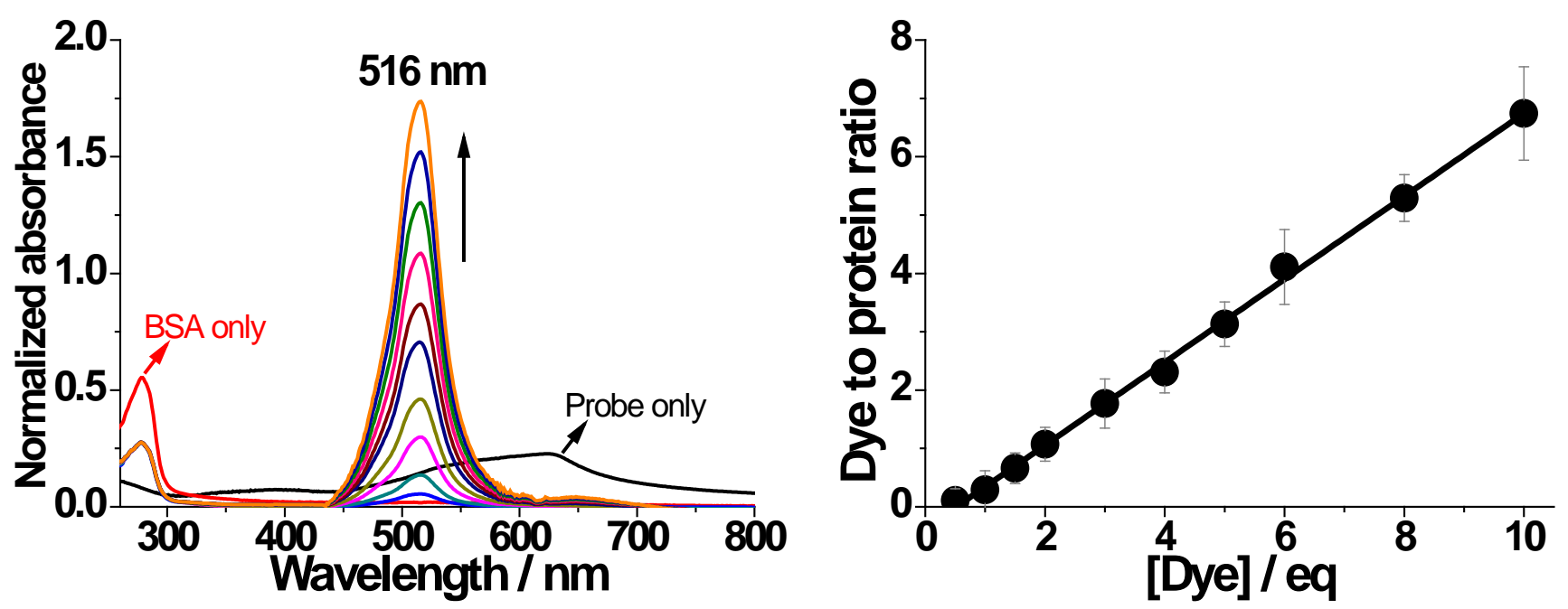

Figure S56. (left) Normalized absorption spectra of 2-NHS/BSA conjugate at different dye-to-protein ratios ( $D / P$, $0.11,0.29,0.66,1.07,1.77,2.31,3.13,4.11,5.29,6.74)$ in PBS $(10 \mathrm{mM}, \mathrm{pH} 7.4)$ at $25^{\circ} \mathrm{C}$. (right) Degree of labeling of BSA with 2-NHS as a function of [2-NHS] $(0.5,1,1.5,2,3,4,5,6,8,10$ equiv) used in the labeling reaction. $D / P$ was determined to be 6.74 at 10 equiv of 2-NHS.
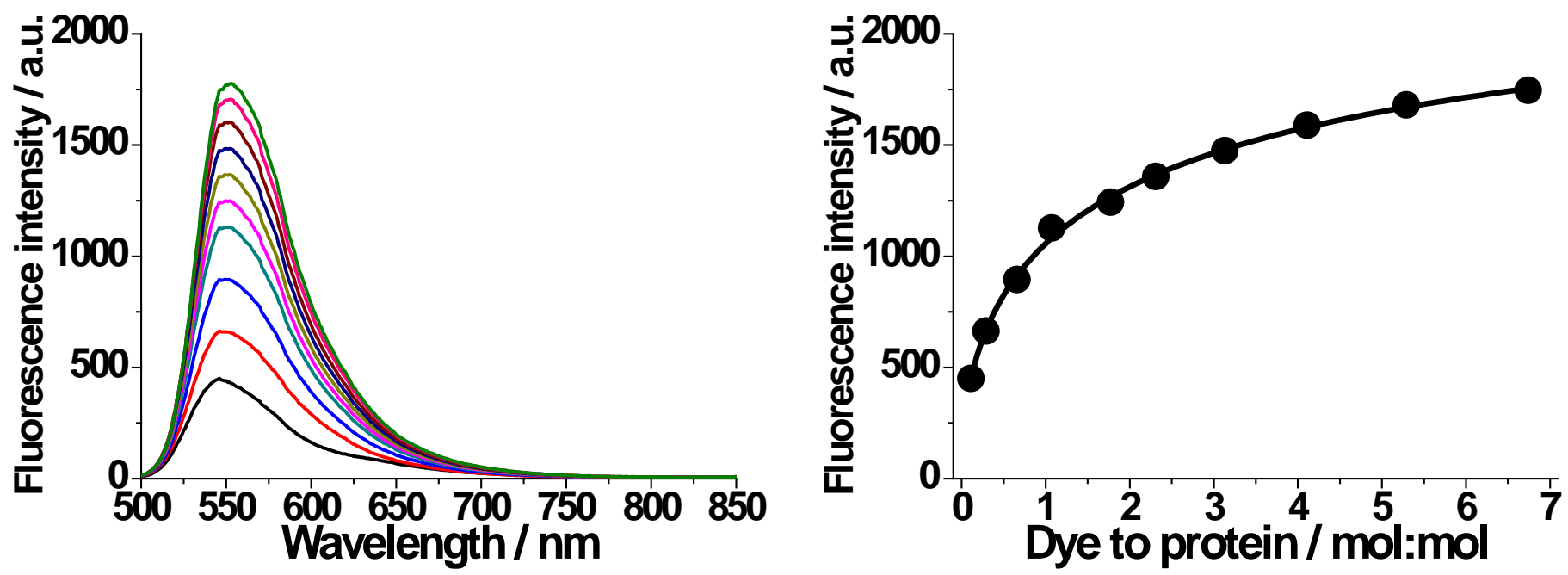

Figure S57. (left) Fluorescence emission spectra of 2-NHS/BSA conjugate at different dye-to-protein ratios $(D / P$, $0.11,0.29,0.66,1.07,1.77,2.31,3.13,4.11,5.29,6.74)$ in PBS $(10 \mathrm{mM}, \mathrm{pH} 7.4)$ at $25{ }^{\circ} \mathrm{C}$. (right) Plot of the fluorescence intensity at $546 \mathrm{~nm}$ of 2-NHS/BSA conjugate vs. the number of conjugated dye on BSA. 


\section{Application of 2-NHS for the Intracellular Protein Labeling and its Fluorescence Microscope Imaging}

\section{Cell culture and reagents}

MCF7 and A2058 (ATCC, Manassas, VA, USA) cells were cultured in Dulbecco's modified Eagle medium supplemented with 10\% fetal bovine serum (Caisson, North Logan, UT, USA) and 1\% penicillin-streptomycin (Caisson). Cells were grown in an incubator at $37^{\circ} \mathrm{C}$ with $5 \% \mathrm{CO}_{2}$.

\section{Confocal fluorescence analysis}

The fluorescence analysis was carried out as described in the literature. ${ }^{11}$ MCF7 and A2058 $\left(2 \times 10^{4}\right)$ cells were seeded onto 12-mm cover slips. After $24 \mathrm{~h}$ incubation, cells were washed twice with phosphate-buffered saline (PBS) and incubated with $10 \mu \mathrm{M}$ of 2-NHS for the indicated time in PBS buffer (pH 7.4) containing $1 \% \mathrm{CH}_{3} \mathrm{CN}$. After washing two times with growth media, the cells were fixed with 4\% paraformaldehyde for 15 min and mounted with DAPI (ImmunoBioScience Corp, Mukilteo, WA, USA). Fluorescence images were taken on a Zeiss LSM 800 confocal laser scanning microscope (Carl Zeiss, Gottingen, Germany). Fluorescence intensity was quantified using the Zen software (Carl Zeiss). To examine changes in cellular endocytosis, the fixed cells were permeabilized with $0.2 \%$ Triton X-100 (Sigma-Aldrich) in PBS with 0.1\% Tween-20 (PBST) for 15 min at room temperature. After washing with the growth media once and the PBST twice, cells were blocked with $2.5 \%$ bovine serum albumin (BSA) in PBST for $1 \mathrm{~h}$ at room temperature. Following washing three times with PBST, the cells were incubated overnight at $4^{\circ} \mathrm{C}$ with the anti-EEA1 antibody (1:100 dilution; Invitrogen) in PBST containing 2.5\% BSA. After washing three times with PBST, the cells were stained with the goat anti-rabbit IgG labeled with Alexa 546 (1:1000 dilution; Invitrogen). 


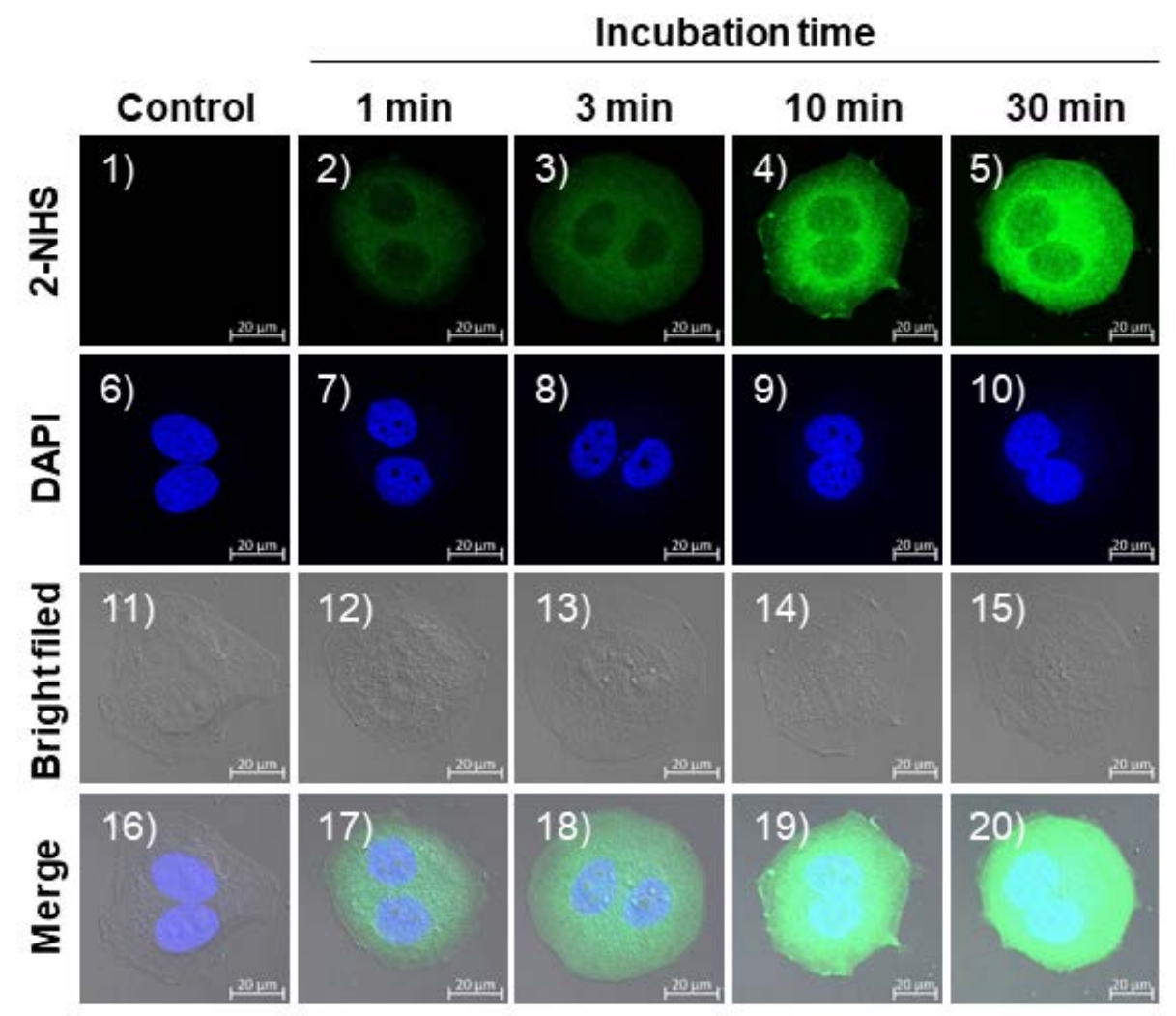

Figure S58. Confocal fluorescence microscope images of MCF7 cells incubated with 2-NHS (10 $\mu \mathrm{M})$ for the indicated time $(0,1,3,10$ or $30 \mathrm{~min})$ at $37^{\circ} \mathrm{C}$. The cells were co-stained with the blue fluorescent DNA-binding dye DAPI. (top to bottom) Green channel for the proteins covalently labeled using 2-NHS $(\mathrm{Ex}=488 \mathrm{~nm}$, Em = 525-617 nm, \#1-\#5); blue channel for DAPI (Ex = $405 \mathrm{~nm}, \mathrm{Em}=410-515 \mathrm{~nm}, \# 6-\# 10)$; bright-field images (\#11-\#15); merged images (\#16-\#20) from the three channels. Control: the unstained cells. Scale bar $=20 \mu \mathrm{m}$. 
(a)
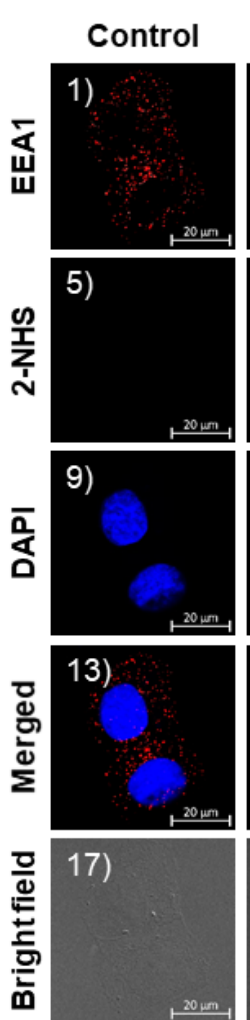

Incubation time with 2-NHS
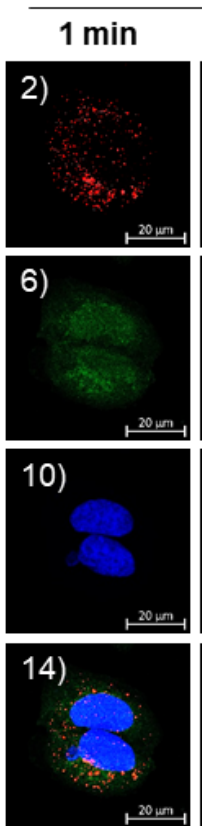

18)
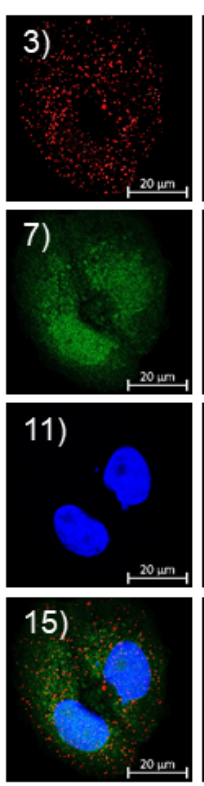

19)

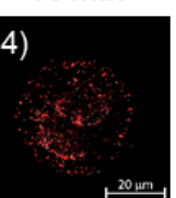

8)
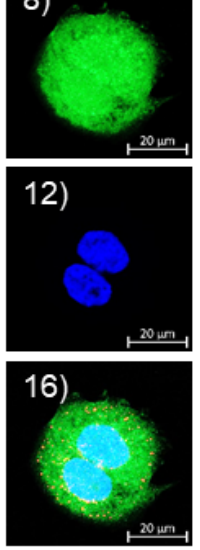

20) (b)
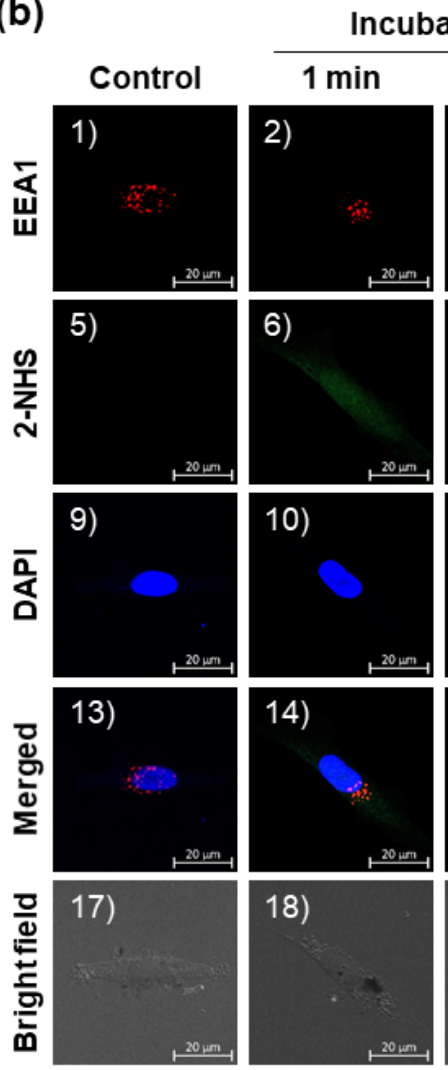
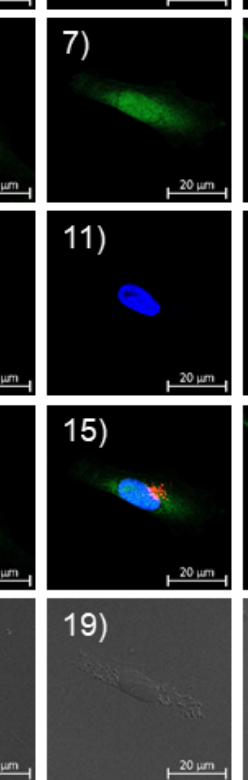
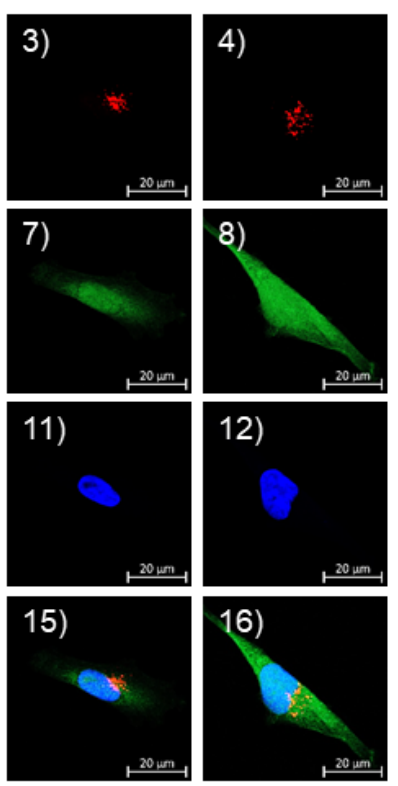

20)

Figure S59. Confocal fluorescence images of MCF-7 human breast cancer cells (a) and A2058 human melanoma cells (b) incubated with 2-NHS $(10 \mu \mathrm{M})$ for the indicated time $(0,1,3$, and $10 \mathrm{~min})$ at $37^{\circ} \mathrm{C}$. An anti-EEA1 antibody was used to localize the early endosome marker EEA1, following staining with a fluorophore-labeled secondary antibody. The cells were also co-stained with the blue fluorescent DNA binding dye DAPI. (\#1-\#4) Red channel for EEA1: Ex $=560 \mathrm{~nm}, \mathrm{Em}=510-590 \mathrm{~nm}$; (\#5-\#8) Green channel for the proteins covalently labeled using 2-NHS: $\mathrm{Ex}=488 \mathrm{~nm}, \mathrm{Em}=525-617 \mathrm{~nm}$; (\#9-\#12) Blue channel for DAPI: Ex $=405 \mathrm{~nm}$, Em =410-515 nm; (\#13-\#16) merged images; (\#17-\#20) bright-field images. Control: cells not incubated with 2NHS. Scale bar $=20 \mu \mathrm{m}$. 
MCF7 and A2058 $\left(1 \times 10^{4}\right)$ cells were seeded in 96-well plates and cultured for overnight to allow cell attachment. The cells were washed with twice with PBS and incubated with 2-NHS (0-10 $\mu \mathrm{M})$ for 30 min in PBS buffer (pH 7.4) containing $1 \% \mathrm{CH}_{3} \mathrm{CN}$, and then the cells were incubated with growth media for 5 min to remove free probes remained in the media. After replacing with fresh growth culture media, the cell viability was measured at $24 \mathrm{~h}$ incubation using CellTiter-Glo Assay (Promega, Madison, WI, USA), according to the manufacturer's instructions.

(a)

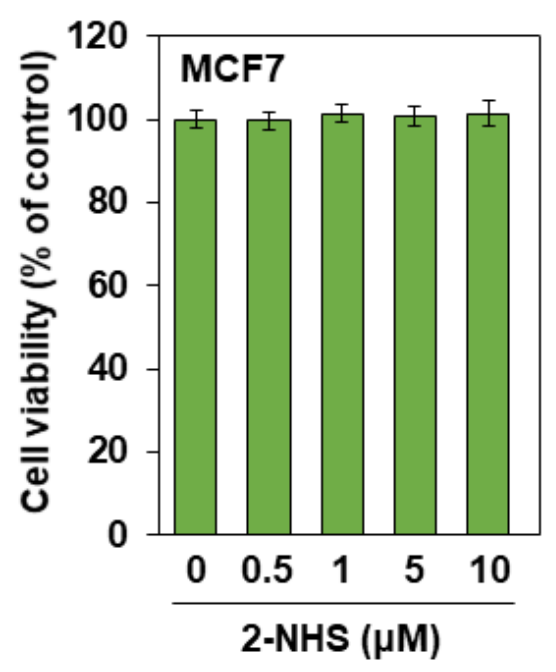

(b)

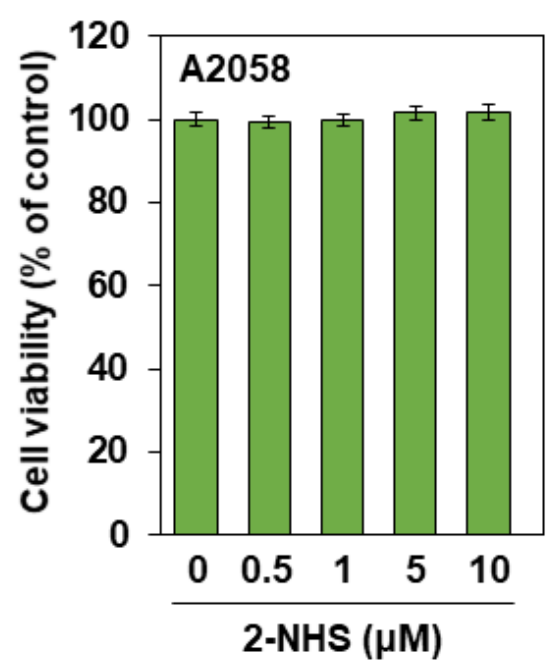

Figure S60. Assessment of cytotoxicity of 2-NHS. Cell viability assays were performed in MCF-7 (a) and A2058 (b) cells following $24 \mathrm{~h}$ incubation of cells with increasing concentrations of 2-NHS. Data are presented as the mean \pm SEM of three independent experiments performed in triplicate. 
A2058 $\left(3 \times 10^{6}\right)$ cells were incubated with $30 \mu \mathrm{M}$ of 2-NHS for $30 \mathrm{~min}$ in PBS buffer (pH 7.4) containing 1\% $\mathrm{CH}_{3} \mathrm{CN}$, and then the cells were incubated with growth media for $5 \mathrm{~min}$. After removing free probes, the cells $\left(0.3 \times 10^{6}\right)$ were reseeded on four $100 \mathrm{~mm}$ dish for cell division tracking. The cells were collected at every day (Day 0-4) and fixed with 2\% paraformaldehyde for cell tracking analysis. All fixed cells were washed with PBS and analyzed using flow cytometry (BD Biosciences, San Jose, CA, USA).

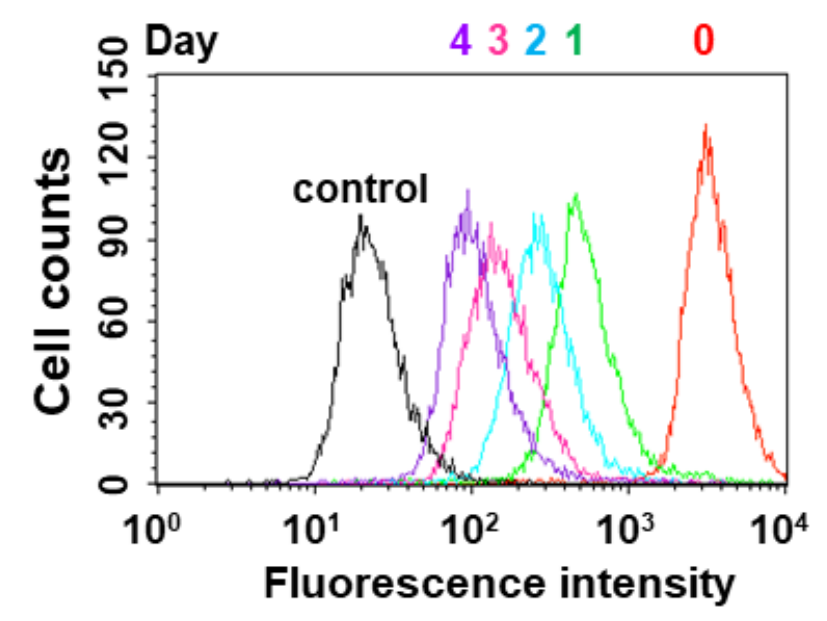

Figure S61. Assessment of 2-NHS as a cell lineage tracker. A2058 cells were incubated with 2-NHS for 30 min in PBS buffer ( $\mathrm{pH} 7.4,1 \% \mathrm{CH}_{3} \mathrm{CN}$ ). Cell division tracking assay was performed for 4 days after culturing cells in fresh complete medium. Cells were collected at each day, fixed with $2 \%$ paraformaldehyde until analyzed by flow cytometry. The control presents unstained cells. 


\section{Application for Organelle-Specific Fluorescence Microscope Imaging}

(a) Synthesis of organelle-specific meso-amide BODIPY dyes (3-ER, 3-Mito and 3-Lyso)

Organelle-specific meso-amide BODIPY dyes 3-ER, 3-Mito and 3-Lyso were obtained from 2-NHS and phenyl sulfonamide (endoplas-mic reticulum targeting), triphenylphosphonium (mitochondria targeting), and morpholine (lysosome targeting) derivatives (Scheme S2).

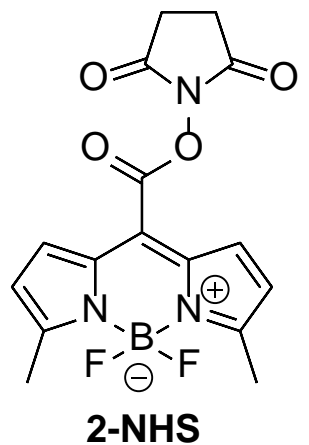

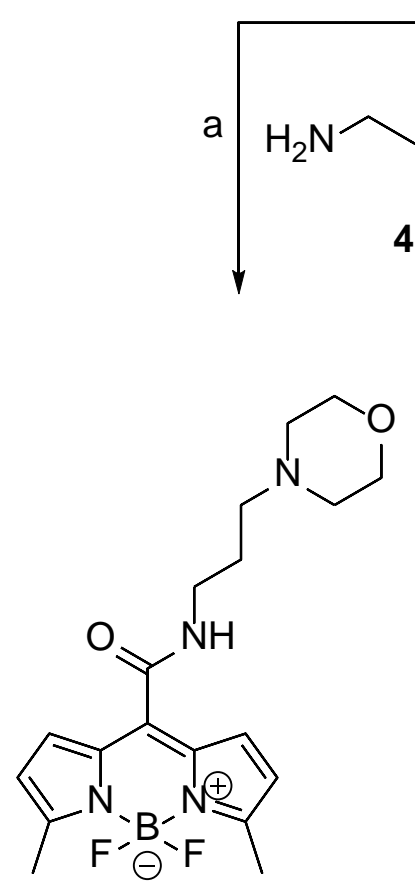

3-Lyso

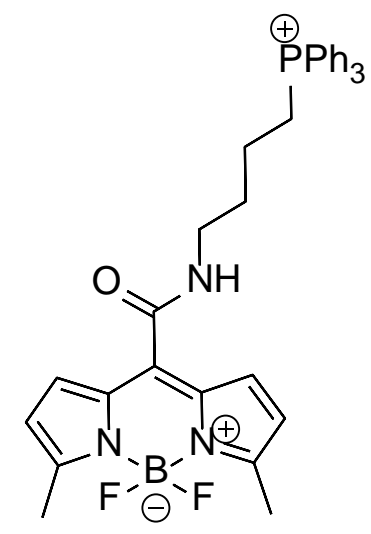

3-Mito<smiles>Cc1ccc(S(=O)(=O)NCCCN)cc1</smiles>

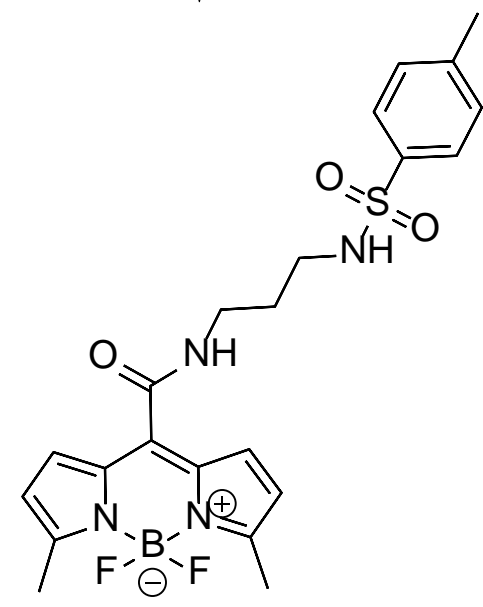

3-ER

Scheme S2. Synthetic scheme for meso-amide BODIPY dyes 3-Lyso, 3-Mito, and 3-ER, reagents and conditions. (a) DMF, RT, 1 hour, 68\% (3-Lyso) 56\% (3-Mito) 75\% (3-ER).

3-Lyso. To a stirred solution of 2-NHS (10 mg, $0.028 \mathrm{mmol}$ ) in DMF (2 mL) at room temperature under a nitrogen atmosphere was added $4^{2}(8.1 \mathrm{mg}, 0.056 \mathrm{mmol})$. After stirring at room temperature for 1 hour, the reaction solvent was removed under reduced pressure. The crude product was then purified by column chromatography on silica gel using progressively more polar 100:1 to 50:1 dichloromethane:methanol as the mobile phase to afford compound 3-Lyso as a red-solid (7.4 mg, 68\%). ${ }^{1} \mathrm{H}-\mathrm{NMR}$ (400 MHz, $\left.\mathrm{CDCl}_{3}\right): \delta=8.07$ (s, 1H), 7.10 (s, 2H), 6.29 
(s, 2H), 4.88 (s, 1H), 3.58 (m, 2H), $3.46(\mathrm{~s}, 4 \mathrm{H}), 2.63(\mathrm{~s}, 6 \mathrm{H}), 2.51$ (m, 2H), $2.41(\mathrm{~s}, 4 \mathrm{H}), 1.77(\mathrm{~m}, 2 \mathrm{H}) ;{ }^{13} \mathrm{C}-\mathrm{NMR}$ (100 MHz, $\mathrm{CDCl}_{3}$ ): $\delta=163.2,159.9,134.7,132.3,129.4,120.1,66.7,58.2,53.6,40.6,24.0,15.1$; HR-MS (ESI): calcd. For $\mathrm{C}_{19} \mathrm{H}_{25} \mathrm{BF}_{2} \mathrm{~N}_{4} \mathrm{O}_{2}[\mathrm{M}+\mathrm{H}]^{+}$391.2118, found 391.2117.

3-Mito. To a stirred solution of 2-NHS (10 mg, $0.028 \mathrm{mmol}$ ) in DMF (2 mL) at room temperature under a nitrogen atmosphere was added $5^{3}$ (18.7 $\mathrm{mg}, 0.056 \mathrm{mmol}$ ). After stirring at room temperature for 1 hour, the reaction solvent was removed under reduced pressure. The crude product was then purified by column chromatography on silica gel using progressively more polar 50:1 to 20:1 dichloromethane:methanol as the mobile phase to afford compound 3-Mito as a red-solid (9.1 mg, 56\%). ${ }^{1} \mathrm{H}-\mathrm{NMR}\left(400 \mathrm{MHz}, \mathrm{CD}_{3} \mathrm{OD}\right): \delta=7.78$ (m, 16H), 6.89 (d, $J=4$ $\mathrm{Hz}, 2 \mathrm{H}), 6.35$ (d, $J=4 \mathrm{~Hz}, 2 \mathrm{H}), 3.50(\mathrm{~m}, 4 \mathrm{H}), 2.56(\mathrm{~s}, 6 \mathrm{H}), 1.88(\mathrm{~m}, 2 \mathrm{H}), 1.77$ (m, $2 \mathrm{H}) ;{ }^{13} \mathrm{C}-\mathrm{NMR}(100 \mathrm{MHz}$, $\left.\mathrm{CD}_{3} \mathrm{OD}\right): \delta=164.5,159.6,135.0,134.6,133.5,132.0,130.3,129.0,120.0,118.8,118.0,38.4,21.3,20.7,19.8$, 13.6; HR-MS (ESI): calcd. For $\mathrm{C}_{34} \mathrm{H}_{34} \mathrm{BF}_{2} \mathrm{~N}_{3} \mathrm{OP}[\mathrm{M}]^{+} 580.2502$, found 580.2501.

3-ER. To a stirred solution of 2-NHS (10 mg, $0.028 \mathrm{mmol})$ in DMF (2 mL) at room temperature under a nitrogen atmosphere was added $\mathbf{6}^{4}$ (12.8 $\left.\mathrm{mg}, 0.056 \mathrm{mmol}\right)$. After stirring at room temperature for 1 hour, the reaction solvent was removed under reduced pressure. The crude product was then purified by column chromatography on silica gel using progressively more polar 5:1 to 1:1 hexanes:ethyl acetate as the mobile phase to afford compound 3-ER as a red-solid (9.7 mg, 75\%). ${ }^{1} \mathrm{H}-\mathrm{NMR}\left(400 \mathrm{MHz}, \mathrm{CDCl}_{3}\right): \delta=7.73(\mathrm{~d}, J=8.0 \mathrm{~Hz}, 2 \mathrm{H}), 7.29$ (d, $J=8.0 \mathrm{~Hz}, 2 \mathrm{H}), 6.80$ (d, $J=4.0 \mathrm{~Hz}, 2 \mathrm{H}), 6.28$ (d, $J=4.0 \mathrm{~Hz}, 3 \mathrm{H}), 5.17$ (t, $J=6.4 \mathrm{~Hz}, 1 \mathrm{H}), 3.58$ (m, 2H), 3.02 (m, 2H), 2.60 (s, 6H), 2.41 (s, 3H), 1.79 (m, 2H); ${ }^{13} \mathrm{C}-\mathrm{NMR}$ (100 MHz, $\left.\mathrm{CDCl}_{3}\right): \delta=143.3,136.9,133.5,132.3$, 129.8, 129.7, 129.3, 127.1, 127.0, 120.4, 39.9, 36.7, 29.9, 21.5, 15.2; HR-MS (ESI): calcd. For $\mathrm{C}_{22} \mathrm{H}_{25} \mathrm{BF}_{2} \mathrm{~N}_{4} \mathrm{O}_{3} \mathrm{~S}$ $[\mathrm{M}-\mathrm{H}]^{+}$473.1638, found 473.1637 . 
(b) Photophysical properties of meso-amide-BODIPY dyes (3-ER, 3-Mito and 3-Lyso)

Table S5. Photophysical properties of compounds ${ }^{a}$

\begin{tabular}{ccccc}
\hline Compounds & $\begin{array}{c}\lambda_{\text {abs. max }} \\
{[\mathrm{nm}]}\end{array}$ & $\begin{array}{c}\varepsilon^{b} \\
{\left[\mathrm{M}^{-1} \mathrm{~cm}^{-1}\right]}\end{array}$ & $\begin{array}{c}\lambda_{\mathrm{em} . \max }{ }^{c} \\
{[\mathrm{~nm}]}\end{array}$ & $\Phi_{\mathrm{FL}}{ }^{d}$ \\
\hline 3b (CONHMe) & 519 & 78000 & 549 & 0.83 \\
3-Lyso & 520 & 55000 & 548 & 0.74 \\
3-Mito & 521 & 53000 & 551 & 0.81 \\
3-ER & 520 & 42000 & 550 & 0.76 \\
\hline
\end{tabular}

${ }^{a}$ In PBS solution (10 mM, pH 7.4, 1\% $\left.\mathrm{CH}_{3} \mathrm{CN}\right) .{ }^{b}$ Measured at each absorption maximum. ${ }^{c}$ Excited at $470 \mathrm{~nm}$. ${ }^{d}$ Quantum yields vs. Rhodamine $6 \mathrm{G}$ in ethanol $\left(\Phi_{\mathrm{FL}}=0.94\right) .{ }^{6}$
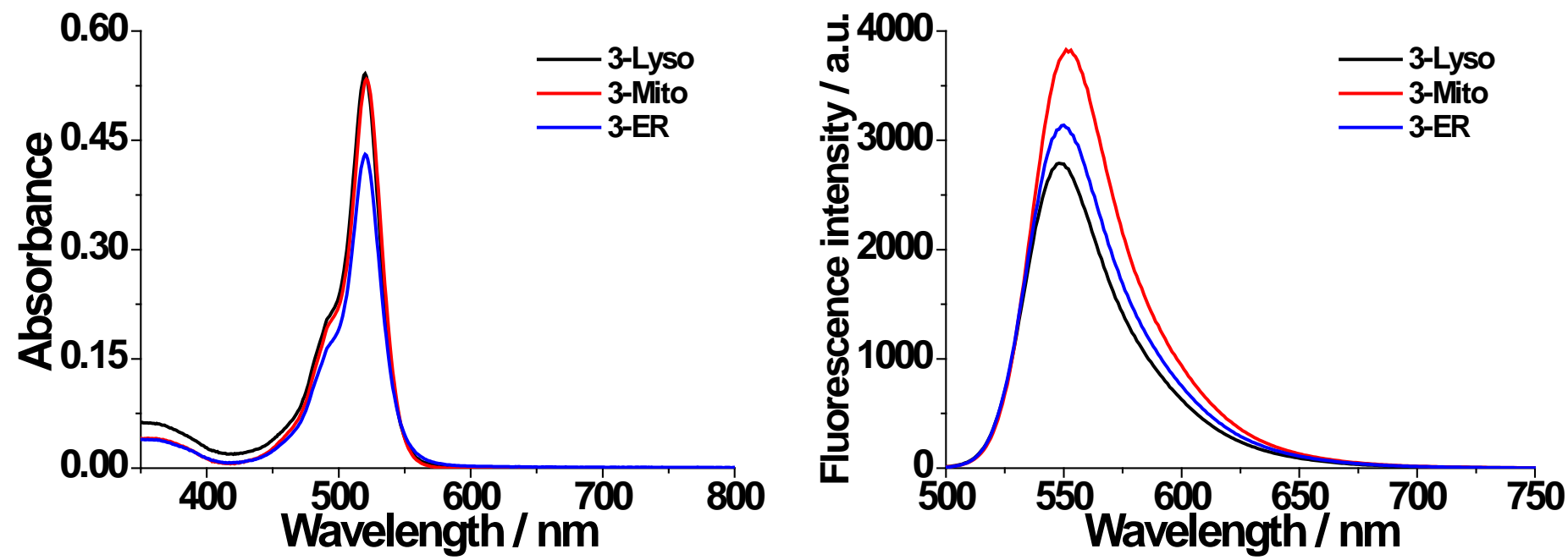

Figure S62. Absorption (left) and fluorescence emission (right) spectra of 3-Lyso (black), 3-Mito (red) and 3ER (blue) in PBS solution (10 mM, pH 7.4, 1\% $\mathrm{CH}_{3} \mathrm{CN}$ ) at $25^{\circ} \mathrm{C}$. Excited at $470 \mathrm{~nm}$. [Compound] $=10 \mu \mathrm{M}$. 

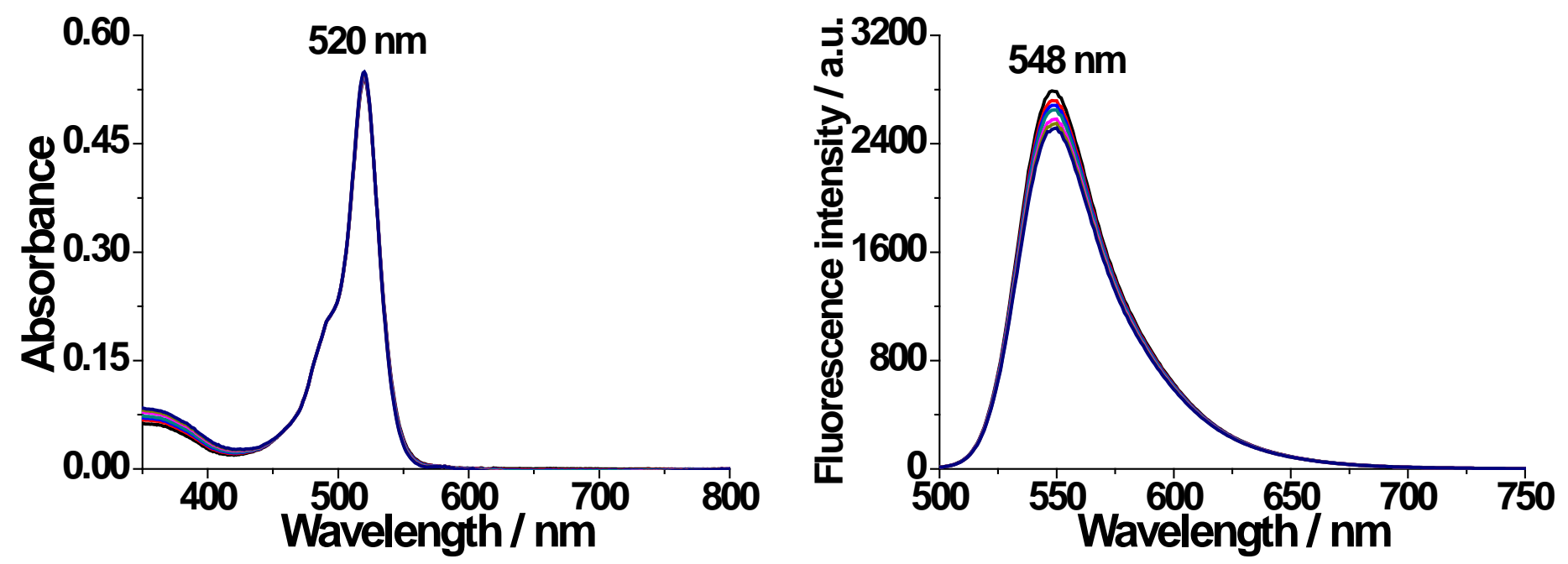

Figure S63. Stability of 3-Lyso to background hydrolysis. Time-dependent absorption (left) and fluorescence emission (right) spectra of 3-Lyso in PBS solution $\left(10 \mathrm{mM}, \mathrm{pH} 7.4,1 \% \mathrm{CH}_{3} \mathrm{CN}\right)$ at $25{ }^{\circ} \mathrm{C}$. The spectra were obtained every 1 hour (0-6 h). Excited at $470 \mathrm{~nm}$. [3-Lyso] $=10 \mu \mathrm{M}$.
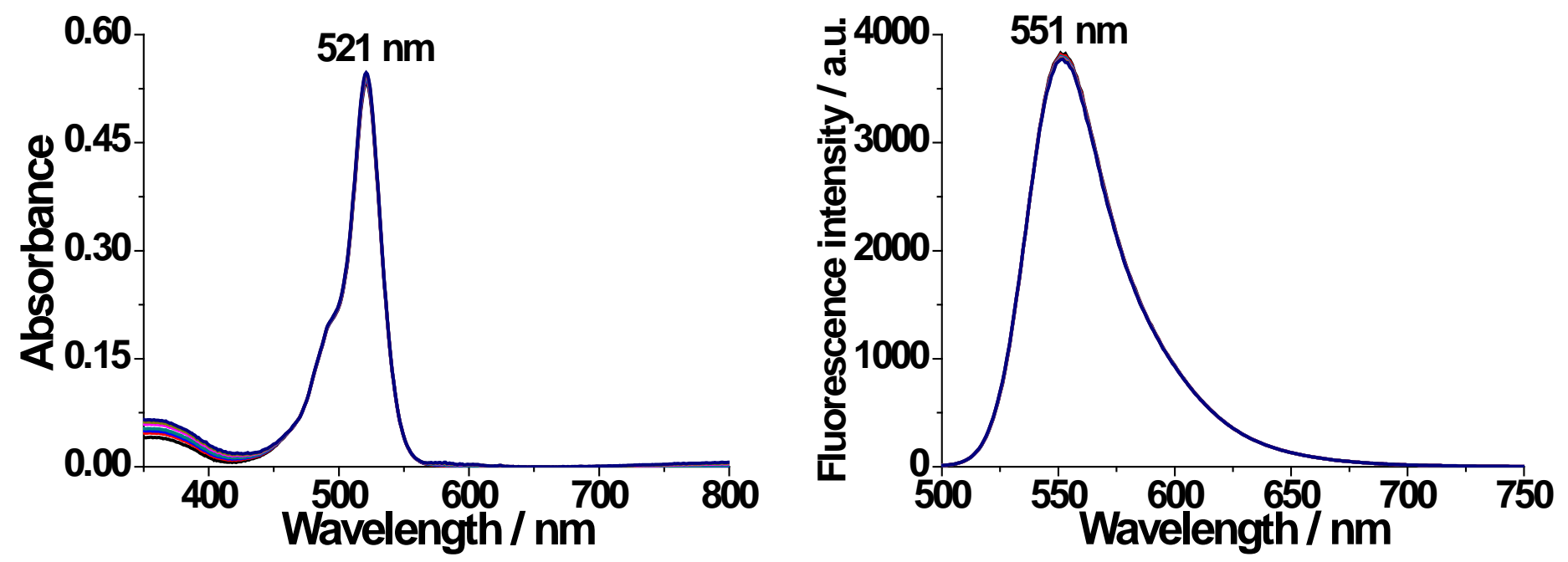

Figure S64. Stability of 3-Mito to background hydrolysis. Time-dependent absorption (left) and fluorescence emission (right) spectra of 3-Mito in PBS solution $\left(10 \mathrm{mM}, \mathrm{pH} 7.4,1 \% \mathrm{CH}_{3} \mathrm{CN}\right)$ at $25{ }^{\circ} \mathrm{C}$. The spectra were obtained every 1 hour (0-6 h). Excited at $470 \mathrm{~nm}$. [3-Mito] $=10 \mu \mathrm{M}$. 

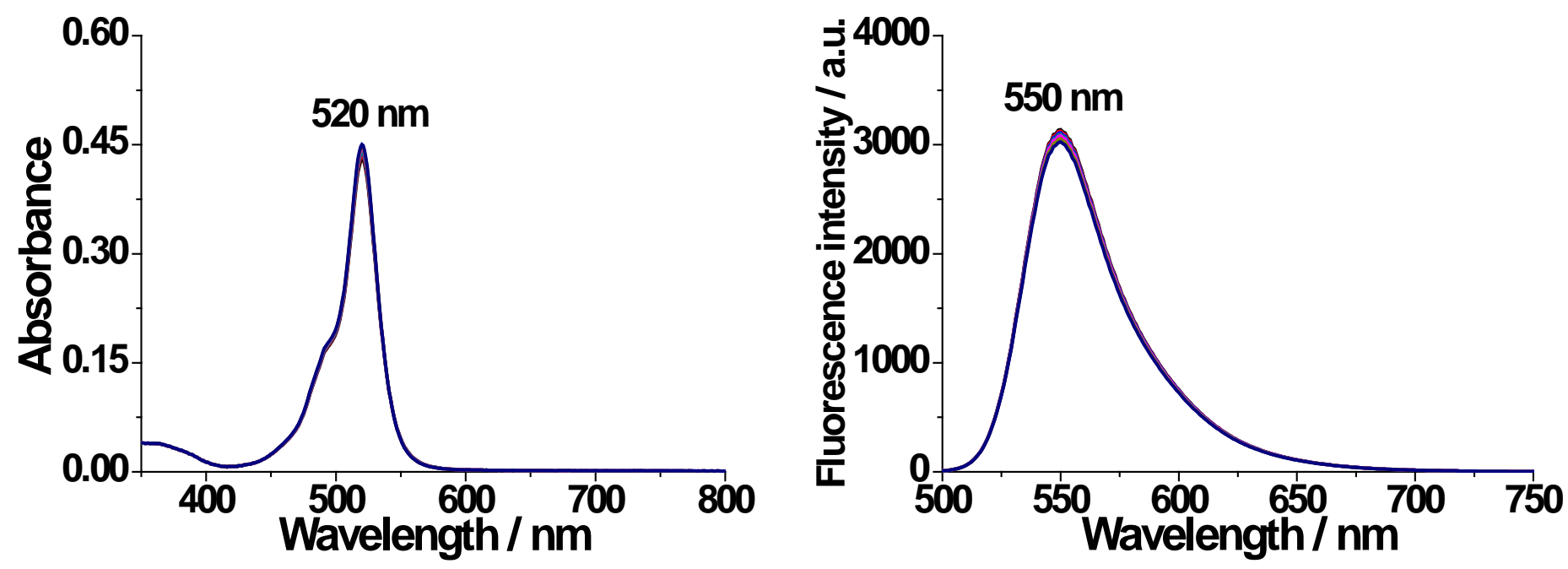

Figure S65. Stability of 3-ER to background hydrolysis. Time-dependent absorption (left) and fluorescence emission (right) spectra of 3-ER in PBS solution $\left(10 \mathrm{mM}, \mathrm{pH} 7.4,1 \% \mathrm{CH}_{3} \mathrm{CN}\right)$ at $25{ }^{\circ} \mathrm{C}$. The spectra were obtained every 1 hour (0-6 h). Excited at $470 \mathrm{~nm}$. [3-ER] $=10 \mu \mathrm{M}$. 


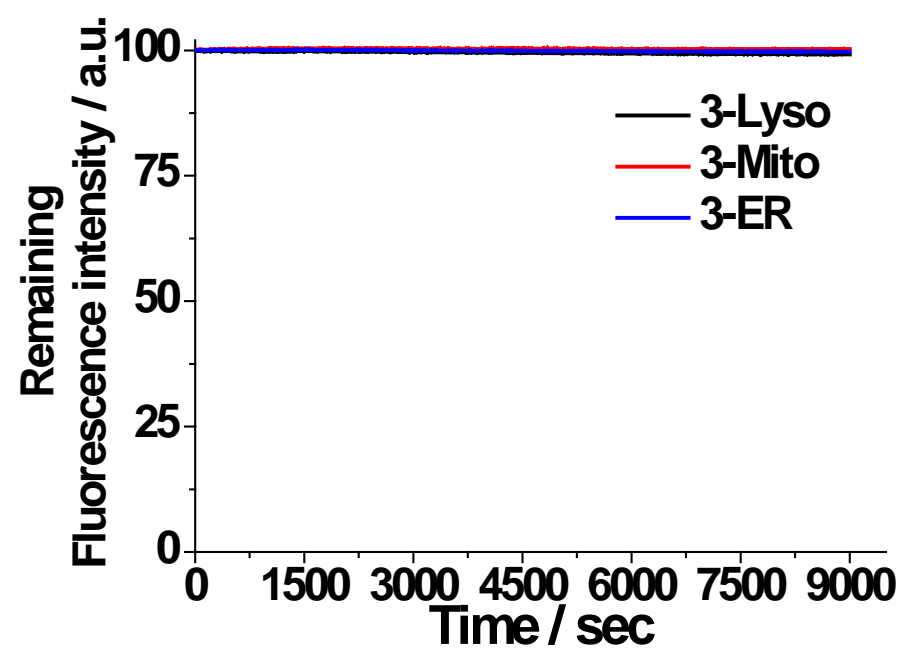

Figure S66. Photostability of 3-ER, 3-Mito, and 3-Lyso in PBS solution (10 mM, pH 7.4, 1\% $\left.\mathrm{CH}_{3} \mathrm{CN}\right)$ at $25{ }^{\circ} \mathrm{C}$. The remaining fluorescence emission intensities of 3-ER, 3-Mito, and 3-Lyso as a function of irradiation time. The photooxidation studies were performed by continuous irradiation (470 nm visible light) using a $150 \mathrm{~W}$ steadystate Xe-lamp as the irradiation source under aerobic conditions for 2.5 hours. The photoinduced degradation was quantified by monitoring the decrease of fluorescence intensity at $550 \mathrm{~nm}$ for 3-ER, $551 \mathrm{~nm}$ for 3-Mito, and 548 $\mathrm{nm}$ for 3-Lyso, respectively, as a function of elapsed photolysis time. A negligible decrease $(0.3 \%$ for 3-Lyso, $0.26 \%$ for 3 -Mito, $0.82 \%$ for 3-ER) in the fluorescence intensity was observed. [Compound] $=10 \mu \mathrm{M}$. 
Cell culture and reagents

HeLa (Korean Cell Line Bank, Seoul, Korea) cells were cultured in Dulbecco's modified Eagle medium supplemented with 10\% fetal bovine serum (Caisson, North Logan, UT, USA) and 1\% penicillin-streptomycin (Caisson). Cells were grown in an incubator at $37^{\circ} \mathrm{C}$ with $5 \% \mathrm{CO}_{2}$.

\section{Confocal fluorescence analysis}

The fluorescence analysis was carried out as described in the literature. ${ }^{11} \mathrm{HeLa}\left(2 \times 10^{4}\right)$ cells were incubated with $10 \mu \mathrm{M}$ of each organelle specific probe (3-ER, 3-Mito, and 3-Lyso) at $37^{\circ} \mathrm{C}$. After $2 \mathrm{~h}$ incubation, cells were washed twice with phosphate-buffered saline (PBS) and incubated with $1 \mu \mathrm{M}$ of ERTraker ${ }^{\mathrm{TM}}$ Red (E34250; Invitrogen, Carlsbad, CA, USA), 500 nM of LysoTracker ${ }^{\circledR}$ Red DND-99 (L7528; Invitrogen) and 100 nM of MitoTracker ${ }^{\mathrm{TM}}$ Orange CMTMRos (M7510; Invitrogen) for $30 \mathrm{~min}$ at $37^{\circ} \mathrm{C}$. After washing three times with PBS with $0.1 \%$ Tween 20 (PBST), cells were fixed with 4\% paraformaldehyde for $15 \mathrm{~min}$. Images were taken by a Zeiss LSM 800 confocal laser scanning microscope (Carl Zeiss, Gottingen, Germany).

\section{Cell viability assay}

HeLa $\left(1 \times 10^{4}\right)$ cells were seeded in 96-well plates and cultured for overnight to allow cell attachment. Then, the cells were treated with indicated probes (3-ER, 3-Mito, and 3-Lyso) at various concentrations $(0-300 \mu \mathrm{M})$. After $24 \mathrm{~h}$ incubation, the cell viability was measured using CellTiter-Glo Assay (Promega, Madison, WI, USA), according to the manufacturer's instructions.

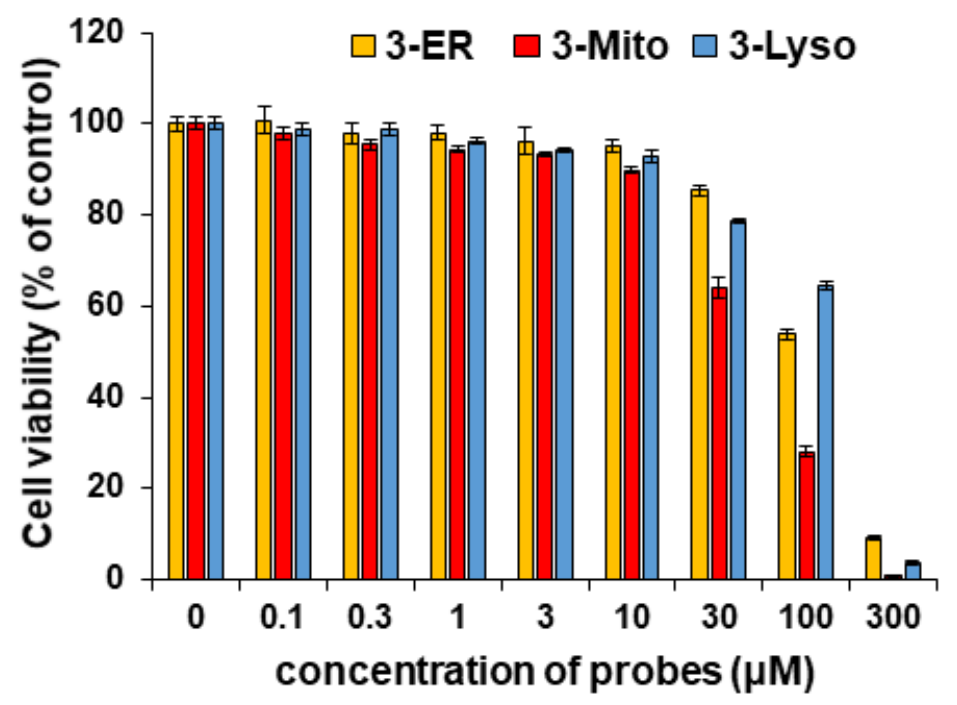

Figure S67. Cell viability assay in HeLa cells after the incubation with various concentrations of 3-ER, 3-Mito, and 3-Lyso for $24 \mathrm{~h}$. Data are presented as the mean \pm SEM of three independent experiments performed in triplicate. 
Table S6. Comparison of the fluorogenic labeling probes for amine-containing biomolecules

\begin{tabular}{|c|c|c|c|c|}
\hline Structure & $\begin{array}{c}\lambda_{\text {exc }} / \lambda_{\text {em }} \\
{[\mathrm{nm}]^{a}} \\
\text { (conjugate) }^{\text {conjugat }}\end{array}$ & $\begin{array}{c}\text { Reaction } \\
\text { Group }\end{array}$ & $\begin{array}{l}\text { Reaction\&PAGE Conditions } \\
\text { / Limit of Detection (LOD) }\end{array}$ & Reference \\
\hline & $\begin{array}{c}470 / 622 \\
(470 / 546)\end{array}$ & NHS & $\begin{array}{c}5 \text { min (pH 7.4), pre/post-staining, } \\
\text { No washing step } \\
\text { / LOD: } 0.18 \mu \text { g BSA/mL } \\
\text { (solution), } 10 \text { ng (SDS-PAGE) }\end{array}$ & This work \\
\hline & $340 / 455$ & $\begin{array}{l}\text { o- } \\
\text { phthalalde } \\
\text { hyde }\end{array}$ & $\begin{array}{c}5 \text { min (pH 9.5) in the presence of } \\
\text { reducing agent } \\
\text { / LOD: } 1 \text { nmol for alanine }\end{array}$ & $\begin{array}{l}\text { Anal. Chem. } \\
\text { 1971, 43, } 880 \\
-882\end{array}$ \\
\hline & $390 / 475$ & $\begin{array}{l}\text { Fluoresca } \\
\text { mine }\end{array}$ & $\begin{array}{c}0.5 \mathrm{sec}(\mathrm{pH} 9.0) \\
\text { / LOD: } 50 \text { pmol for primary } \\
\text { amine-containing amino acids, } \\
0.05 \mu \mathrm{g} \text { of protein }\end{array}$ & $\begin{array}{l}\text { Science 1972, } \\
\text { 178, 871-872 }\end{array}$ \\
\hline & $470 / 570$ & $\begin{array}{l}\text { Non- } \\
\text { covalent } \\
\text { bonding }\end{array}$ & $\begin{array}{l}30 \text { - } 60 \text { min, post-staining } \\
\text { / LOD: } 1-10 \text { ng (SDS-PAGE) }\end{array}$ & $\begin{array}{l}\text { Anal. } \\
\text { Biochem. } \\
\text { 1996, 239, } \\
\text { 223-237 }\end{array}$ \\
\hline & $\begin{array}{c}621 / 655 \\
(503 / 602)\end{array}$ & $\begin{array}{l}\text { Pyrylium } \\
\text { groups }\end{array}$ & $\begin{array}{l}10 \text { - } 30 \text { min, (pH 9.0), post- } \\
\text { staining (washing step), } \\
\text { / LOD: } 0.06 \mu \mathrm{g} / \mathrm{mL} \text { (solution) }\end{array}$ & $\begin{array}{l}\text { Angew. Chem. } \\
\text { Int. Ed. 2004, } \\
\text { 43, 5400- } \\
5402\end{array}$ \\
\hline & $377 / 460$ & NCS & $\begin{array}{c}40 \text { min (pH 9.5) / Two photon } \\
\text { imaging }\end{array}$ & $\begin{array}{c}\text { Bioconjugate } \\
\text { Chem. 2008, } \\
\text { 19, } 2559- \\
2567\end{array}$ \\
\hline & $320 / 475$ & NCS & $\begin{array}{l}2 \text { hours (pH 9.0), pre/post-staining } \\
\text { (washing step), AIEE } \\
\text { / LOD: } 0.1 \sim 0.2 \mu \text { g for BSA }\end{array}$ & $\begin{array}{l}\text { Analyst 2012, } \\
\text { 137, 5592- } \\
5596\end{array}$ \\
\hline & $390 / 500$ & Enamine & cyclization & $\begin{array}{l}\text { J. Am. Chem. } \\
\text { Soc. 2014, } \\
\text { 136, 15493- } \\
15496\end{array}$ \\
\hline
\end{tabular}




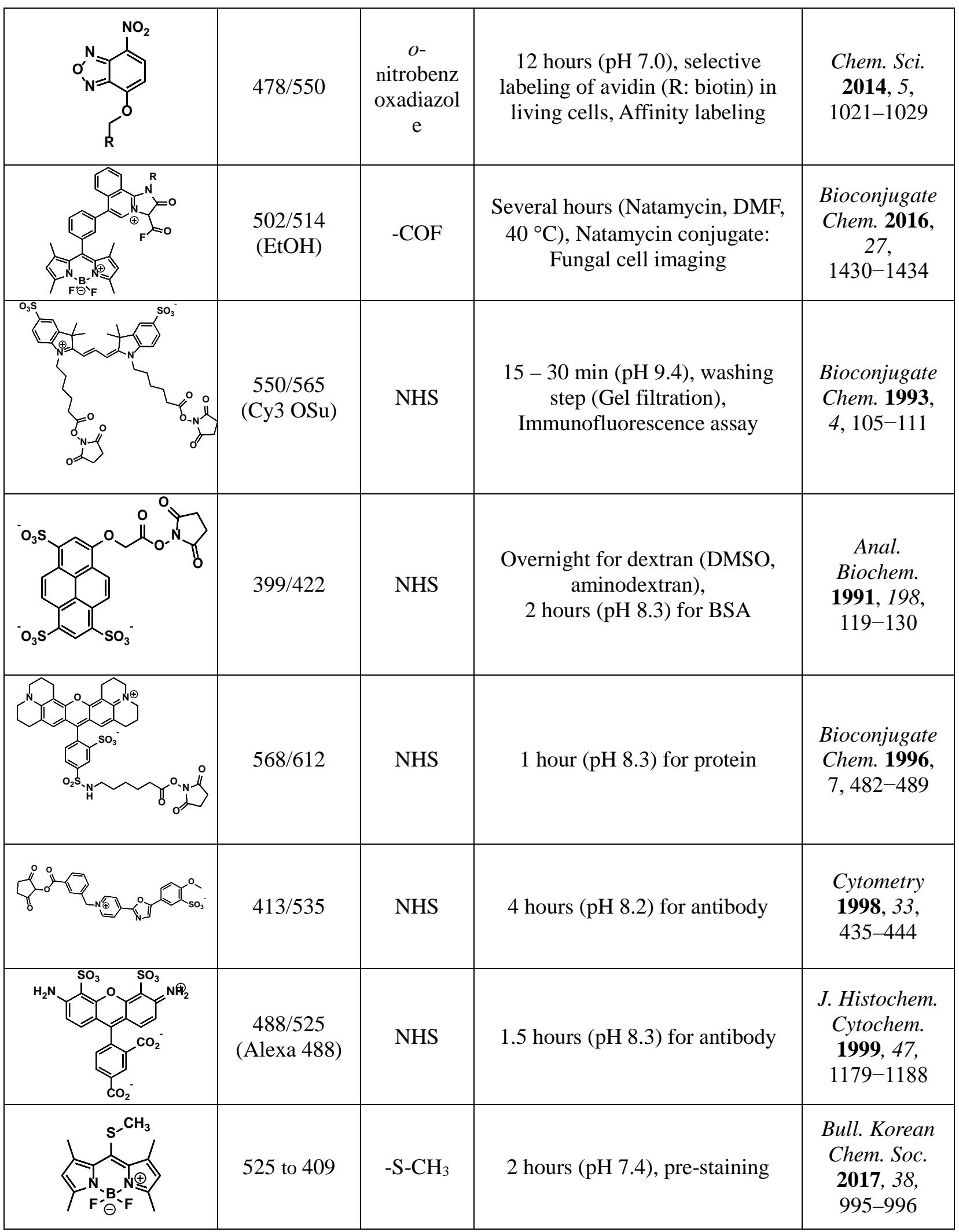




\section{DFT Calculations}

Geometric optimizations were performed in the gas phase at the B3LYP 6-311++G(d,p) level of theory, using the Gaussian 09 software package. ${ }^{12}$ Absolute energies in hartrees are given without additional corrections.
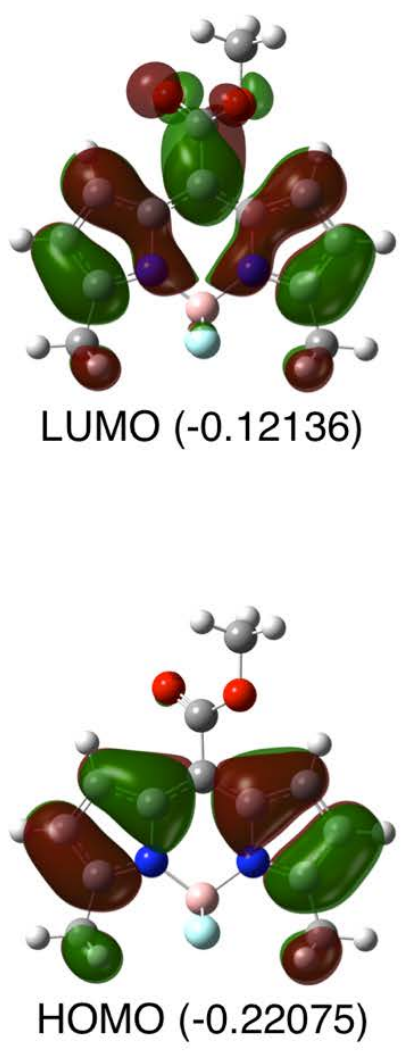

2-Me

\section{Boradiazaindacene /} Carbonyl Angle: $41^{\circ}$
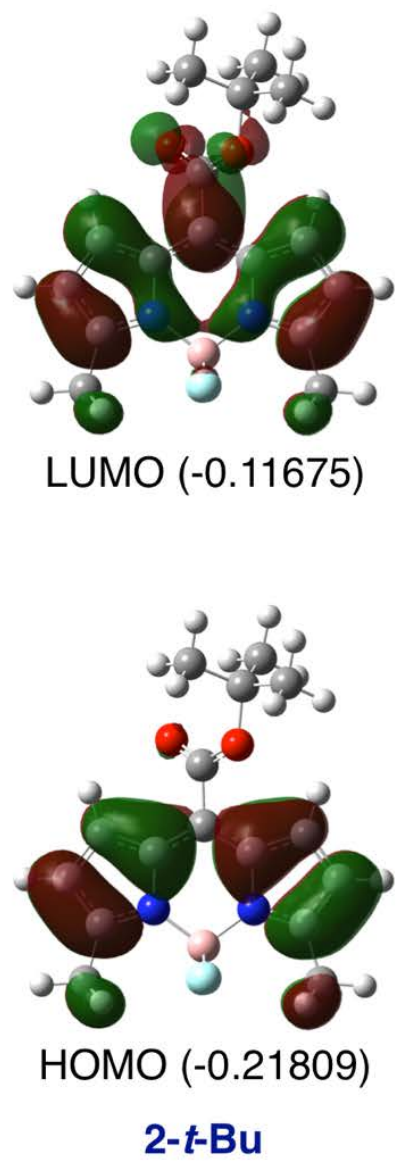

Boradiazaindacene / Carbonyl Angle: $45^{\circ}$
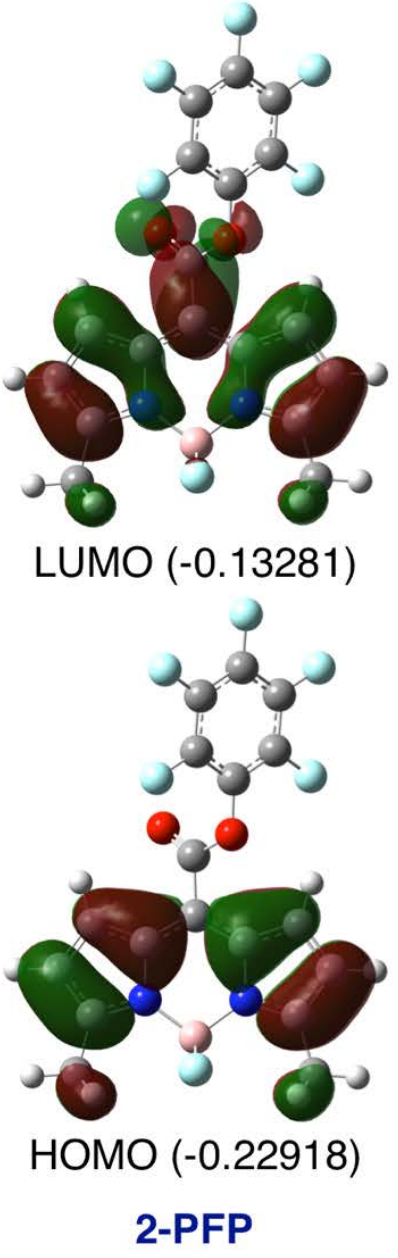

Boradiazaindacene / Carbonyl Angle: $40^{\circ}$

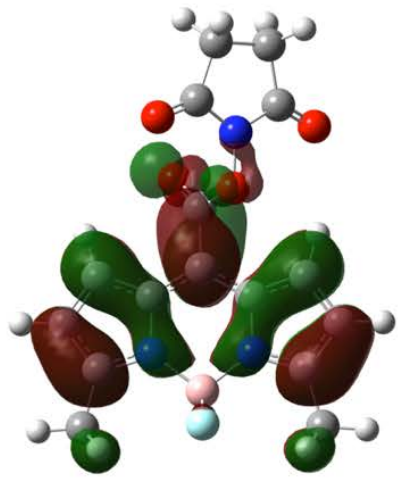

LUMO (-0.12520)

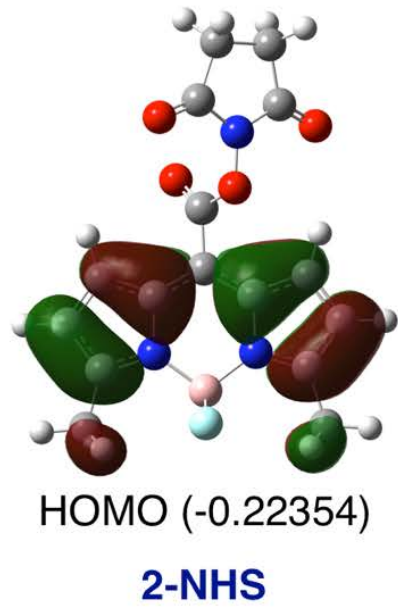

Boradiazaindacene / Carbonyl Angle: $48^{\circ}$

Figure S68. Calculated frontier molecular orbitals for $\mathbf{2}-\mathbf{M e}^{13}$ (left), 2-t-Bu${ }^{13}$ (center left), 2-PFP (center right) and 2-NHS (right), and their orbital energies, highlighting the influence of the meso substituent on the LUMO levels and hence the energy gap. 


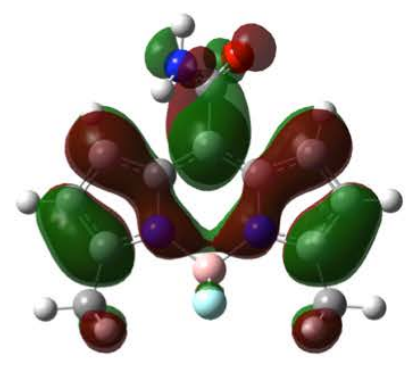

LUMO (-0.11880)

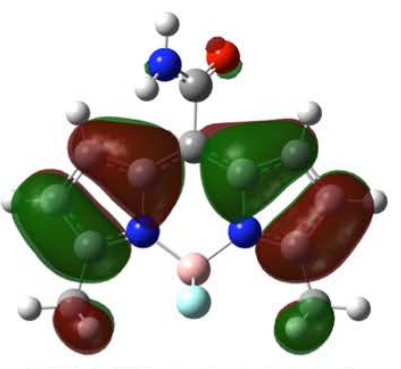

HOMO (-0.22301)

3a $\left(\mathrm{NH}_{2}\right)$

Boradiazaindacene / Carbonyl Angle: $51^{\circ}$

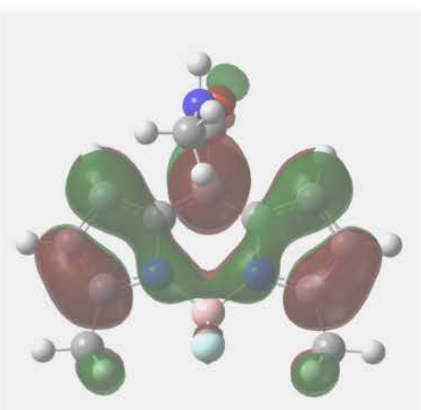

LUMO (-0.11389)

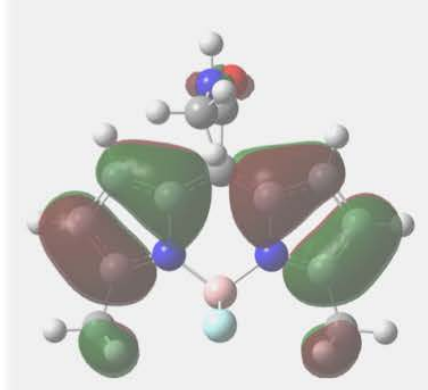

HOMO (-0.22133)

$$
\text { E-3b (NHMe) }
$$

Boradiazaindacene / Carbonyl Angle: $76^{\circ}$

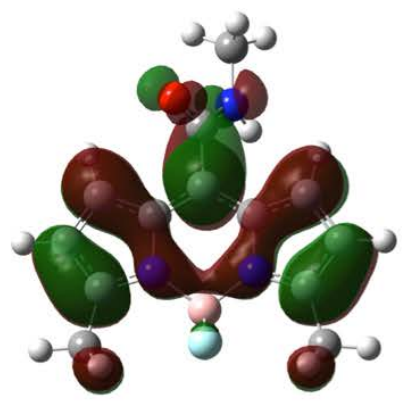

LUMO (-0.11640)

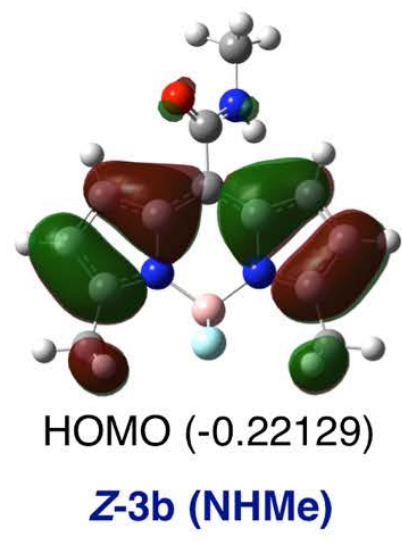

Boradiazaindacene / Carbonyl Angle: $51^{\circ}$

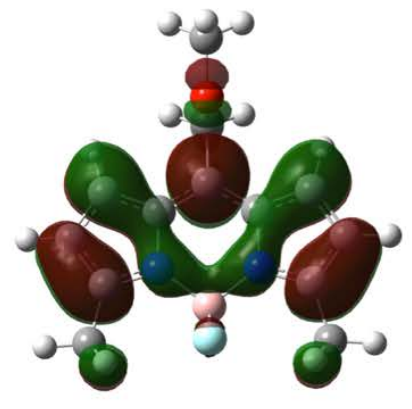

LUMO (-0.11156)

Figure S69. Calculated frontier molecular orbitals for 3a (left), $\boldsymbol{E}$-3b (center left), $\mathbf{Z}$-3b (center right) and 3c (right), and their orbital energies, highlighting the influence of the meso substituent on the LUMO levels and hence the energy gap. Note: The $\mathbf{Z}-\mathbf{3 b}$ isomer being ca. $3.1 \mathrm{kcal} / \mathrm{mol}$ more stable than the $\boldsymbol{E}-\mathbf{3 b}$, it is likely the only one worth considering for solution fluorescence data. 

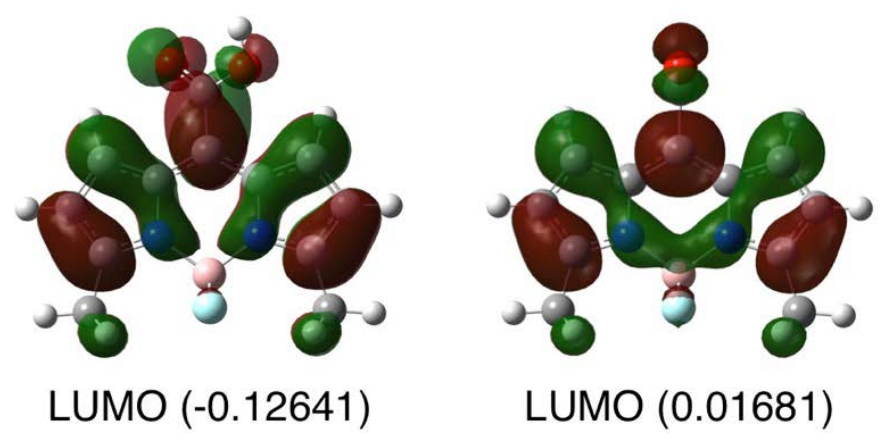

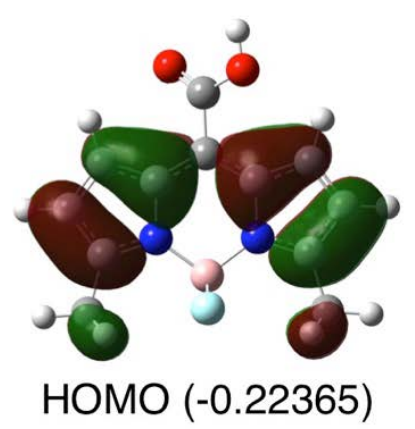

1

Boradiazaindacene / Carbonyl Angle: $36^{\circ}$

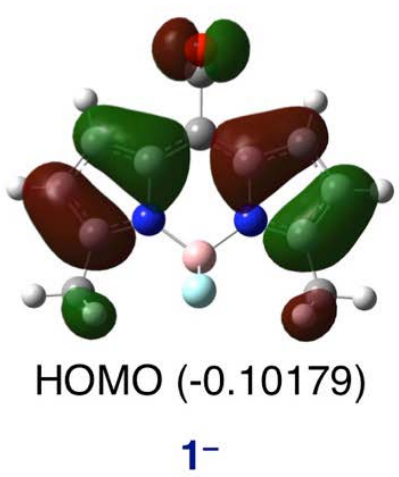

Boradiazaindacene / Carbonyl Angle: $90^{\circ}$

Figure S70. Calculated frontier molecular orbitals for $\mathbf{1}$ (left) and $\mathbf{1}^{-}$(right), and their orbital energies.

- Cartesian Coordinates for 2-Me (Energy : -988.16813808 hartrees): ${ }^{13}$

\begin{tabular}{|c|c|c|c|}
\hline B & 1.82441600 & ๑. $2725720 \odot$ & $\odot . \odot 57 \odot \odot \odot \odot \odot$ \\
\hline $\mathrm{F}$ & 2.52714300 & ๑. $4287080 \odot$ & 1.25889400 \\
\hline $\mathrm{F}$ & 2.69874700 & $\odot .40493400$ & -1.02906300 \\
\hline $\mathrm{N}$ & ๑. 68831000 & 1.33675700 & $-\odot .0390690 \odot$ \\
\hline $\mathrm{N}$ & 1.13239200 & -1.12294400 & ๑. 01895500 \\
\hline C & ๑. 85620200 & 2.67492300 & $-\odot .07692300$ \\
\hline C & -0.41188800 & 3. 29744900 & -0.16163200 \\
\hline $\mathrm{H}$ & $-\odot .57610500$ & 4.36313300 & $-\odot .2056350 \odot$ \\
\hline C & -1.36797900 & 2.29892900 & -0.17091100 \\
\hline C & -0.67894900 & 1.05939300 & -0.09211400 \\
\hline C & -1.13545100 & $-\odot .2633160 \odot$ & -0.11086800 \\
\hline C & -0.24311300 & -1.33774900 & $-\odot .07093800$ \\
\hline C & $-\odot .46639500$ & -2.74146200 & $-\odot .0713310 \odot$ \\
\hline C & ๑.7725240๑ & -3.34666600 & ๑. 01663500 \\
\hline $\mathrm{H}$ & ๑. 98556900 & -4.40441900 & $\odot .03574400$ \\
\hline C & 1.74866800 & -2.32163600 & ๑. 07130100 \\
\hline C & 3. 22779400 & -2.47113700 & 0.17032600 \\
\hline $\mathrm{H}$ & 3. 72207900 & -1.99537500 & -0.68076800 \\
\hline $\mathrm{H}$ & 3.60635300 & -1.98045600 & 1.07094600 \\
\hline $\mathrm{H}$ & 3. 49997700 & -3.52641700 & $\odot .19716800$ \\
\hline C & 2.19441400 & 3. 32889900 & $-\odot .0303840 \odot$ \\
\hline
\end{tabular}




\begin{tabular}{|c|c|c|c|}
\hline $\mathrm{H}$ & $2.7361850 \odot$ & $3.0375540 \odot$ & ๑.8732270๑ \\
\hline $\mathrm{H}$ & 2.80679900 & 3. 01783900 & $-\odot .8808510 \odot$ \\
\hline $\mathrm{H}$ & $2.0848780 \odot$ & 4.41344100 & $-\odot . \odot 4719 \odot \odot \odot$ \\
\hline $\mathrm{H}$ & -2.43744700 & 2.41402000 & -0.21598100 \\
\hline $\mathrm{H}$ & -1.43093900 & -3.21421500 & $-\odot .1510490 \odot$ \\
\hline $\mathrm{C}$ & $-2.6024020 \odot$ & $-\odot .5797270 \odot$ & $-\odot .2069230 \odot$ \\
\hline 0 & -3.06114600 & -1.47471700 & $-\odot .8739840 \odot$ \\
\hline 0 & -3.34909200 & ๑. 23955900 & $\odot .55331600$ \\
\hline $\mathrm{C}$ & -4.77147200 & $-\odot .00493400$ & ๑. 52780700 \\
\hline $\mathrm{H}$ & -4.98721200 & -1.01308300 & $\odot .8826470 \odot$ \\
\hline $\mathrm{H}$ & $-5.2014950 \odot$ & $\odot .73793900$ & 1.19525700 \\
\hline $\mathrm{H}$ & -5.15846600 & 0.11118300 & -0.48513200 \\
\hline
\end{tabular}

- Cartesian Coordinates for 2-t-Bu (Energy : -1106.1492995 hartrees): ${ }^{13}$

\begin{tabular}{|c|c|c|c|}
\hline B & $2.5803250 \odot$ & $\odot .28644100$ & $\odot .11902900$ \\
\hline $\mathrm{F}$ & 3.19012000 & $\odot .44963600$ & $1.37 \odot 2350 \odot$ \\
\hline $\mathrm{F}$ & 3.53348000 & $\odot .42400600$ & $-\odot .89826300$ \\
\hline $\mathrm{N}$ & 1.44695900 & 1.34169100 & $-\odot .06435800$ \\
\hline $\mathrm{N}$ & 1.90407000 & -1.11455900 & ๑. 03110300 \\
\hline C & 1.60543300 & 2.68125400 & $-\odot .09310400$ \\
\hline C & ๑. 34182500 & 3. 29219900 & $-\odot .27164700$ \\
\hline $\mathrm{H}$ & $\odot .17204700$ & 4.35636000 & $-\odot .3302170 \odot$ \\
\hline C & -0.60224100 & 2.28422500 & -0.34708700 \\
\hline C & $\odot .08956500$ & 1.05217100 & -0.21630600 \\
\hline C & -0.35534800 & -0.27294200 & -0.26861100 \\
\hline C & 0.54072000 & -1.33935300 & -0.16365000 \\
\hline C & ๑. 32949600 & -2.74393000 & $-\odot .1849580 \odot$ \\
\hline C & 1.56288000 & -3.34064900 & $-\odot .00303200$ \\
\hline $\mathrm{H}$ & 1.78216100 & -4.39684700 & $\odot .02937500$ \\
\hline C & 2.52370000 & -2.30867700 & $\odot .12833900$ \\
\hline C & 3.99224700 & -2.44703200 & $\odot .34059200$ \\
\hline $\mathrm{H}$ & 4.54693500 & -1.96405200 & $-\odot .4680890 \odot$ \\
\hline $\mathrm{H}$ & 4.29616500 & -1.95754200 & 1.26969500 \\
\hline $\mathrm{H}$ & $4.2698300 \odot$ & -3.50036900 & ๑. $3846110 \odot$ \\
\hline C & 2.93139800 & 3.34682600 & $\odot .0505250 \odot$ \\
\hline $\mathrm{H}$ & 3.40977300 & 3.05693900 & $\odot .98958400$ \\
\hline $\mathrm{H}$ & 3.60563100 & $3.0445 \odot 40 \odot$ & $-\odot .755142 \odot \odot$ \\
\hline $\mathrm{H}$ & 2.81375100 & 4.43050200 & $\odot .0290650 \odot$ \\
\hline $\mathrm{H}$ & -1.66677200 & 2.38810400 & -0.46929200 \\
\hline $\mathrm{H}$ & -0.62186400 & -3.22425300 & $-0.3418860 \odot$ \\
\hline C & -1.81453200 & -0.60210900 & -0.47500200 \\
\hline 0 & -2.19036400 & -1.45882600 & -1.23972000 \\
\hline 0 & -2.59787900 & $\odot .15328200$ & ๑. $3018680 \odot$ \\
\hline C & -4.08098400 & ๑. 00107500 & ๑. 31495000 \\
\hline C & -4.45049900 & -1.40793900 & ๑. 78201500 \\
\hline $\mathrm{H}$ & -5.53226100 & -1.46207800 & $\odot .93034900$ \\
\hline $\mathrm{H}$ & -4.16366400 & -2.16202500 & 0.05081400 \\
\hline $\mathrm{H}$ & -3.96766900 & -1.63257300 & 1.73630600 \\
\hline C & -4.50579300 & 1.04473300 & 1.34699800 \\
\hline $\mathrm{H}$ & -4.20322100 & 2.04669000 & 1.03519700 \\
\hline $\mathrm{H}$ & $-5.5923860 \odot$ & 1.03217800 & 1.46052800 \\
\hline $\mathrm{H}$ & -4.05255300 & $\odot .83413300$ & $2.3177980 \odot$ \\
\hline C & -4.64940100 & ๑. $3295220 \odot$ & $-1.0669060 \odot$ \\
\hline $\mathrm{H}$ & -4.34834300 & -0.40609500 & -1.81117400 \\
\hline $\mathrm{H}$ & -5.74121900 & $\odot .33952500$ & -1.01003500 \\
\hline $\mathrm{H}$ & -4.32241800 & 1.32010500 & -1.39348200 \\
\hline
\end{tabular}

- Cartesian Coordinates for 2-PFP (Energy : -1676.2435678 hartrees):

$\begin{array}{rrrr}\text { B } & 4.02588177 & 0.20625549 & 0.17073830 \\ \mathrm{~F} & 4.62892548 & 0.10996777 & 1.42992150 \\ \mathrm{~F} & 4.98574443 & 0.50688601 & -0.80182332 \\ \mathrm{~N} & 2.92297941 & 1.31093602 & 0.18914734\end{array}$




\begin{tabular}{|c|c|c|c|}
\hline $\mathrm{N}$ & 3.30921240 & -1.13319959 & $-\odot .18324347$ \\
\hline C & 3.12244710 & 2.62730160 & ๑. 40733183 \\
\hline C & 1.87909100 & 3. 30182293 & ๑. 33515573 \\
\hline $\mathrm{H}$ & 1.74289590 & 4.36396532 & ๑. 46810188 \\
\hline C & ๑. 90529126 & 2.35884066 & ๑. 07060531 \\
\hline C & 1.55927225 & 1.09936693 & -0.01836145 \\
\hline C & 1.08244920 & $-\odot .18161606$ & $-\odot .31437540$ \\
\hline C & 1.94211424 & -1.27889464 & -0.41200373 \\
\hline C & 1.68700957 & -2.64998362 & -0.68991377 \\
\hline C & 2.90125054 & -3.30456785 & -0.62746446 \\
\hline $\mathrm{H}$ & 3. 08860955 & -4.35482884 & $-\odot .7894150 \odot$ \\
\hline C & 3.89307889 & -2.34272381 & -0.31081780 \\
\hline $\mathrm{C}$ & 5.35560259 & -2.56020315 & -0.13324817 \\
\hline $\mathrm{H}$ & 5.92400219 & -1.96881513 & -0.85617989 \\
\hline $\mathrm{H}$ & 5.67541478 & -2.23712687 & $\odot .86091867$ \\
\hline $\mathrm{H}$ & 5.60037882 & -3.61435149 & -0.26337143 \\
\hline C & 4.46481200 & 3.21309140 & ๑. 67912323 \\
\hline $\mathrm{H}$ & 4.91592311 & 2.75148955 & 1.56156397 \\
\hline $\mathrm{H}$ & 5.14408610 & 3.02764457 & $-\odot .15704680$ \\
\hline $\mathrm{H}$ & 4.38199709 & 4.28780689 & ๑.84114813 \\
\hline $\mathrm{H}$ & -0.15180612 & 2.52621602 & -0.04851316 \\
\hline $\mathrm{H}$ & $\odot .72161515$ & -3.06915208 & -0.92031821 \\
\hline C & -0.36907192 & -0.42752293 & -0.57263163 \\
\hline 0 & -0.82604615 & -1.13665810 & -1.42063676 \\
\hline 0 & -1.16058876 & ๑. 26374461 & ๑. 32860958 \\
\hline C & -2.52574121 & ๑. 11080184 & $\odot .21083477$ \\
\hline C & -3.16789701 & -1.01836295 & ๑. 71064990 \\
\hline C & -3.28888381 & 1.12786608 & -0.35289337 \\
\hline C & -4.55129169 & -1.13035505 & ๑. 65038093 \\
\hline C & -4.67342345 & 1.02796179 & -0.41400149 \\
\hline C & -5.30430558 & -0.10467670 & ๑. 08830925 \\
\hline $\mathrm{F}$ & -2.68508244 & 2.21704821 & -0.84101879 \\
\hline $\mathrm{F}$ & -5.39613746 & 2.01226387 & -0.95143969 \\
\hline $\mathrm{F}$ & -6.63192218 & -0.20696874 & ๑. 03299056 \\
\hline $\mathrm{F}$ & -5.15963159 & -2.21532807 & 1.13229222 \\
\hline $\mathrm{F}$ & -2.45029763 & -2.00318585 & 1.25510336 \\
\hline
\end{tabular}

\footnotetext{
- Cartesian Coordinates for 2-NHS (Energy : -1308.35356635 hartrees):

3.13441600

3.76402400

4. 07267800

2. 02465200

2. 41984900

2.21225900

0.96041300

0.81657400

$-0.00906900$

0.66047500

0.19071300

1.05100100

0.79364200

2. 01148100

2. 19891400

3. 00485500

4.47076000

5.02826600

4.80188600

4.71759400

3.55228000

4. 01239400

4.22687900

3.46306500

0.22712800

$\odot .25053100$

0.44085900

1.32529700

$-1.14466600$

2. 65806900

3. 31219200

4. 38115900

2. 34155400

1.08690800

$-0.21591700$

$-1.31524900$

$-2.70378800$

$-3.34875700$

$-4.40947200$

$-2.36082900$

$-2.55890400$

$-2.02718000$

$-2.15590400$

$-3.61964600$

3.27811200

2. 91588500

3.00858400

4.36345000

0.13270200

1.38194500

$-0.88349300$

0.07162500

$-0.08160800$

$\odot .16234100$

0.04441600

0.07727000

$-0.11650200$

$-0.09565800$

$-0.26645800$

$-0.27566000$

$-0.42201600$

$-0.31644600$

$-0.38073900$

$-0.10516100$

0.07075100

$-0.70497500$

1. 03150700

$\odot .02395800$

0.35970500

1. 28304900

$-0.45709800$

0.40740300
} 


\begin{tabular}{|c|c|c|c|}
\hline $\mathrm{H}$ & $-1.0713060 \odot$ & 2.48339800 & $-\odot .2433220 \odot$ \\
\hline $\mathrm{H}$ & $-\odot .1756810 \odot$ & -3.14401100 & $-\odot .5922590 \odot$ \\
\hline C & $-1.2626290 \odot$ & $-\odot .4710940 \odot$ & $-\odot .4896520 \odot$ \\
\hline 0 & -1.75780100 & -1.13122800 & -1.34998900 \\
\hline 0 & -2.00735600 & $\odot .17896700$ & $\odot .4982320 \odot$ \\
\hline C & $-4.0846230 \odot$ & -1.05437400 & ๑. 79109100 \\
\hline C & -4.09539000 & 1.04464500 & -0.34185100 \\
\hline C & -5.53470400 & $-\odot .7807340 \odot$ & ๑. 41981400 \\
\hline C & -5.54329400 & $\odot .58344800$ & -0.30055100 \\
\hline $\mathrm{H}$ & -5.88439800 & -1.59989900 & $-\odot .2109090 \odot$ \\
\hline $\mathrm{H}$ & -6.13457700 & -0.79211600 & 1.33151300 \\
\hline $\mathrm{H}$ & -5.91554600 & $\odot .52787500$ & -1.32489000 \\
\hline $\mathrm{H}$ & $-6.1327600 \odot$ & 1. $3410600 \odot$ & ๑. $2193620 \odot$ \\
\hline 0 & -3.62389100 & 2.04203100 & -0.82132200 \\
\hline 0 & -3.60784400 & -1.99471000 & 1.3635220 \\
\hline $\mathrm{N}$ & -3.36558600 & ๑. 05315200 & ๑. 3182720 \\
\hline
\end{tabular}

- Cartesian Coordinates for 3a (Energy : -928.98508465 hartrees):

\begin{tabular}{|c|c|c|c|}
\hline B & -1.53909516 & $\odot .25158690$ & $\odot .06814593$ \\
\hline $\mathrm{F}$ & -2.22117593 & ๑. 38315750 & 1.28533642 \\
\hline $\mathrm{F}$ & -2.43215487 & ๑. 38727246 & -1.00001323 \\
\hline $\mathrm{N}$ & -0.83017227 & -1.13628463 & ๑. . 0085720 \\
\hline $\mathrm{N}$ & $-\odot .41692655$ & 1.33281214 & -0.03280608 \\
\hline C & -1.42744372 & -2.34455730 & 0.01618894 \\
\hline C & -0.43305895 & -3.35457048 & -0.02120484 \\
\hline $\mathrm{H}$ & -0.63103692 & -4.41540003 & -0.02983101 \\
\hline C & $\odot .79826626$ & -2.72965018 & -0.05485173 \\
\hline C & $\odot .55179467$ & -1.33036376 & -0.04128671 \\
\hline C & 1.42880792 & -0.24845137 & -0.04619539 \\
\hline C & $\odot .95269028$ & 1.06869144 & -0.05764637 \\
\hline C & 1.63171528 & 2.31082747 & $-\odot .15515403$ \\
\hline C & $\odot .66445404$ & 3. 30165866 & -0.17865760 \\
\hline $\mathrm{H}$ & $\odot .81941730$ & 4.36713374 & -0.25169627 \\
\hline C & $-\odot .59749816$ & 2.66894300 & $-\odot .09881912$ \\
\hline C & -1.94312215 & 3.31038523 & -0.08462823 \\
\hline $\mathrm{H}$ & -2.52623467 & 3.00560013 & -0.95760311 \\
\hline $\mathrm{H}$ & -2.50996708 & $3.0 \odot 410545$ & ๑.79828901 \\
\hline $\mathrm{H}$ & -1.84287992 & 4.39603274 & -0.08534917 \\
\hline C & -2.90633196 & -2.51962557 & 0.06726873 \\
\hline $\mathrm{H}$ & -3.32319143 & -2.02943939 & ๑. 95108749 \\
\hline $\mathrm{H}$ & -3.38017924 & -2.05896589 & -0.80346645 \\
\hline H & -3.16110639 & -3.57925323 & ๑. . 09328256 \\
\hline $\mathrm{H}$ & 1.77433020 & -3.18294739 & -0.11423035 \\
\hline H & $2.70 \odot 48784$ & 2.43683266 & $-\odot .22273110$ \\
\hline C & 2.91462302 & -0.53830779 & -0.05178286 \\
\hline 0 & 3.42061054 & -1.30641423 & -0.84855323 \\
\hline $\mathrm{N}$ & 3.63138613 & $\odot .11926930$ & 0.90475160 \\
\hline H & 3.18041524 & $\odot .64079947$ & 1.63880534 \\
\hline $\mathrm{H}$ & 4.61112340 & -0.10544233 & ๑. 99422685 \\
\hline
\end{tabular}

- Cartesian Coordinates for $\boldsymbol{E}$-3b (Energy : -968.29819157 hartrees):

$\begin{array}{rrrr}\text { B } & -1.71653276 & 0.23438824 & 0.09345012 \\ \mathrm{~F} & -2.28769132 & 0.35942125 & 1.36807992 \\ \mathrm{~F} & -2.70293510 & 0.35702417 & -0.88954031 \\ \mathrm{~N} & -1.00033256 & -1.14804373 & -0.03343083 \\ \mathrm{~N} & -0.62009137 & 1.32965066 & -0.10500914 \\ \mathrm{C} & -1.57744397 & -2.36525115 & 0.02985600 \\ \mathrm{C} & -0.57803481 & -3.36011634 & -0.10611270 \\ \mathrm{H} & -0.76091218 & -4.42368971 & -0.10266160 \\ \mathrm{C} & 0.63727923 & -2.71530001 & -0.25144741 \\ \mathrm{C} & 0.37353669 & -1.32348689 & -0.20524764 \\ \mathrm{C} & 1.23080786 & -0.23011421 & -0.30125961 \\ \mathrm{C} & 0.74259922 & 1.07609009 & -0.26286685\end{array}$


1. 40936352

$\odot .44186882$

$\odot .58612198$

$-\odot .80782834$

$-2.14870083$

$-2.80822997$

$-2.63094096$

$-2.05295974$

$-3.04346561$

$-3.38350778$

$-3.60202407$

$-3.28039152$

1. 60886108

2. 47022687

2. 70991263

3. 12032352

3. 52780787

3. 16473948

2. 10360677

3. 72615378

3. 37400542

4.50621276
2. 31964403

3. 30665927

4. 37458425

2. 66564988

3. 30012580

3. 01080763

2. 97230715

4. 38610467

$-2.56090979$

$-2.08270484$

$-2.10226159$

$-3.62425087$

$-3.15963136$

2. 44799903

$-0.47395923$

$-0.79912521$

$-0.31296051$

๑. 03076649

$-0.15097659$

$-0.59775377$

1. 08109339

$-0.45788816$
$-0.38323983$

$-0.29665780$

$-0.35472543$

$-\odot .12077579$

0.02999251

$-0.79252196$

0.95436677

○. 04292246

๑. 21626888

1. 13866679

$-0.60372721$

$\odot .25791111$

$-0.40328901$

$-0.53550422$

$-0.52067322$

$-1.62302722$

0.55386801

1. 92376078

2. 08416987

2. 61818869

2. 14759322

๑. 34114101

- Cartesian Coordinates for Z-3b (Energy : -968.30312749 hartrees):

B

$\mathrm{F}$

$\mathrm{F}$

$\mathrm{N}$

$\mathrm{N}$

C

C

$\mathrm{H}$

C

C

$\mathrm{H}$

$\mathrm{H}$

$\mathrm{H}$

$\mathrm{H}$

C

0

N

C

$\mathrm{H}$

$\mathrm{H}$

$\mathrm{H}$
$-1.83322085$

$-2.44665423$

$-2.79174521$

$-1.08899959$

$-0.75191271$

$-1.64803066$

$-0.62826986$

$-0.79498726$

0.57980827

0.29334495

1.13720484

$\odot .62050136$

1. 25467886

○. 25895110

$\odot .37742158$

$-0.97579100$

$-2.33667865$

$-2.96471413$

$-2.83662409$

$-2.26930351$

$-3.11540418$

$-3.49300241$

$-3.65428583$

$-3.33600042$

1. 56369397

2. 31279811

2. 62796654

3. 10968515

3. 37633661

2. 90247335

4. 81735681

5. 23702292

5. 06607354

5. 26185171
๑. 20647861

0.31696090

๑. 31629899

$-1.15943064$

1. 32066239

$-2.38497366$

$-3.36471968$

$-4.43098465$

$-2.70308913$

$-1.31201010$

$-0.20527956$

1. 09695412

2. 35814893

3. 32053251

4. 39005641

2. 65096764

3. 25194452

2. 92847069

2. 92999500

4. 34012809

$-2.60408540$

$-2.12441417$

$-2.16019625$

$-3.67085695$

$-3.12648098$

2.51541340

$-0.45106147$

$-1.20260516$

๑. 21272860

๑. 73124904

๑. 01817419

$\odot .79158697$

$-0.96491846$

$\odot .09332122$ $\odot .11644902$

1. 37199185

$-0.89695671$

$\odot .00360959$

$-0.04780644$

๑. 05266163

$-0.04699419$

$-0.04623730$

$-0.15351368$

$-0.12172897$

$-0.17734411$

$-0.15916524$

$-0.29827582$

$-0.25981623$

$-0.34174617$

$-0.10126788$

$-0.00160774$

$-0.83580694$

$\odot .91543948$

- 0.00817400

$\odot .19278933$

1. 09967630

$-0.64835833$

$\odot .23482919$

$-0.27385280$

$-0.43390540$

$-0.26996406$

$-1.10267184$

๑. 65180266

1. 37468385

$\odot .74199935$

1. 38522966

1.15287629

$-0.25071554$

- Cartesian Coordinates for 3c (Energy : -1007.61641998 hartrees):

$\begin{array}{ll}\mathrm{B} & 2.00212825 \\ \mathrm{~F} & 2.56625245 \\ \mathrm{~F} & 3.01172248\end{array}$

0.00006730

0.10952578

0.00013111

1.39375268

$\odot .00006397$

$-\odot .85787215$ 


\begin{tabular}{|c|c|c|c|}
\hline $\mathrm{N}$ & 1.08695336 & 1.25367986 & $-\odot .06717556$ \\
\hline $\mathrm{N}$ & 1.08704820 & -1.25362857 & -0.06710848 \\
\hline C & 1.47315796 & 2.54579137 & -0.03407831 \\
\hline $\mathrm{C}$ & $\odot .33746019$ & 3.37321960 & -0.20660059 \\
\hline $\mathrm{H}$ & $\odot .35678459$ & 4.45193457 & -0.23180217 \\
\hline C & -0.76513683 & 2.54683280 & -0.34191645 \\
\hline C & -0.29530825 & 1.21392352 & -0.25425536 \\
\hline C & -0.97647436 & - ๑. . 00005218 & -0.33000498 \\
\hline $\mathrm{C}$ & $-\odot .29523496$ & -1.21395923 & -0.25414654 \\
\hline C & $-\odot .76494920$ & -2.54692317 & - ๑. 34191638 \\
\hline C & $\odot .33769864$ & -3.37321586 & -0.20664368 \\
\hline $\mathrm{H}$ & $\odot .35711792$ & -4.45192749 & -0.23191357 \\
\hline C & 1.47334743 & -2.54569374 & -0.03410264 \\
\hline $\mathrm{C}$ & 2.89105954 & -2.96525676 & ๑. 15810812 \\
\hline $\mathrm{H}$ & 3.52215704 & -2.57302971 & -0.64347495 \\
\hline $\mathrm{H}$ & 3.28804539 & -2.57064977 & 1.09716657 \\
\hline $\mathrm{H}$ & 2.96476275 & -4.05296699 & $\odot .16974750$ \\
\hline C & 2.89085255 & 2.96542100 & ๑. 15810955 \\
\hline $\mathrm{H}$ & 3.28787407 & 2.57087614 & 1.09717762 \\
\hline $\mathrm{H}$ & 3.52194997 & 2.57318921 & -0.64347163 \\
\hline $\mathrm{H}$ & 2.96451492 & 4.05313594 & 0.16969571 \\
\hline $\mathrm{H}$ & -1.79080559 & 2.83742891 & -0.51068969 \\
\hline $\mathrm{H}$ & -1.79061993 & -2.83754765 & -0.51062523 \\
\hline $\mathrm{C}$ & -2.46843603 & - ๑ . 00010111 & $-\odot .597050 \odot 4$ \\
\hline 0 & -2.85451121 & - ๑ . 00015500 & -1.75744525 \\
\hline $\mathrm{C}$ & -4.74309953 & ๑. 00013154 & $\odot .26798002$ \\
\hline $\mathrm{H}$ & -5.19314760 & -0.88831025 & $\odot .72260951$ \\
\hline $\mathrm{H}$ & -5.19283974 & ๑. 88883324 & $\odot .72240522$ \\
\hline $\mathrm{H}$ & -4.94183812 & $\odot .00000464$ & -0.80092175 \\
\hline $\mathrm{N}$ & -3.30017668 & $-\odot . \odot \odot \odot \odot 7577$ & $\odot .48245397$ \\
\hline $\mathrm{C}$ & -2.86035669 & $-\odot .0 \odot \odot 24885$ & 1.87229063 \\
\hline $\mathrm{H}$ & -1.77530062 & $\odot .00016434$ & 1.93519438 \\
\hline $\mathrm{H}$ & -3.23996823 & ๑.88780806 & 2.38823683 \\
\hline $\mathrm{H}$ & -3.23926971 & $-\odot .88883771$ & 2.38784429 \\
\hline
\end{tabular}

- Cartesian Coordinates for 1 (Energy : -948.85721469 hartrees):

\begin{tabular}{|c|c|c|c|}
\hline B & 1.49904900 & ๑. 43012700 & ๑. 01972100 \\
\hline $\mathrm{F}$ & 2.23774600 & $\odot .66505800$ & 1.18624000 \\
\hline$F$ & 2.30108400 & $\odot .64748400$ & -1.10738100 \\
\hline $\mathrm{N}$ & ๑. 25392300 & 1.36842700 & $-\odot .0216390 \odot$ \\
\hline $\mathrm{N}$ & ๑. $9559310 \odot$ & -1.03042000 & ๑ . 01528100 \\
\hline C & ๑. 27992100 & 2.71656600 & -0.06431200 \\
\hline C & -1.04886600 & 3.20382400 & -0.09313200 \\
\hline $\mathrm{H}$ & -1.32479600 & 4.24651000 & -0.12805900 \\
\hline C & -1.89563900 & 2.11233700 & $-\odot .06298900$ \\
\hline C & -1.07796100 & ๑. 95039900 & -0.01576800 \\
\hline C & -1.39204700 & -0.41372600 & -0.01688500 \\
\hline C & -0.39147200 & -1.38973900 & -0.01387400 \\
\hline C & -0.46494300 & -2.80999300 & ๑.00109500 \\
\hline C & $\odot .83335700$ & -3.27990300 & ๑. 03525300 \\
\hline $\mathrm{H}$ & 1.15792400 & -4.30902900 & ๑. . $4489060 \odot$ \\
\hline C & 1.69728800 & -2.15686300 & $\odot .0432420 \odot$ \\
\hline C & 3.18651100 & -2.14863900 & ๑. $0752910 \odot$ \\
\hline $\mathrm{H}$ & 3.58834300 & -1.63546900 & -0.80245100 \\
\hline $\mathrm{H}$ & 3.55071100 & -1.60735100 & $\odot .95250400$ \\
\hline $\mathrm{H}$ & 3.56948800 & -3.16889800 & ๑. 09949600 \\
\hline C & 1.54346600 & 3.50586600 & $-\odot .0733000 \odot$ \\
\hline $\mathrm{H}$ & 2.14344300 & 3.28405000 & $\odot .81327000$ \\
\hline $\mathrm{H}$ & 2.15455900 & 3. 24678400 & $-\odot .94186700$ \\
\hline $\mathrm{H}$ & 1. 32181800 & 4.57294200 & $-\odot .0970730 \odot$ \\
\hline H & -2.97210200 & 2.11626600 & -0.06166200 \\
\hline $\mathrm{H}$ & -1.37607800 & -3.38343800 & -0.03064200 \\
\hline C & -2.81735100 & $-\odot .8815790 \odot$ & -0.0531590 \\
\hline
\end{tabular}




$\begin{array}{lrrr}0 & -3.2061860 \odot & -1.8494980 \odot & -0.65734700 \\ 0 & -3.6447420 \odot & -0.1075500 \odot & 0.68467000 \\ H & -4.5331690 \odot & -0.4868390 \odot & 0.59640200\end{array}$

- Cartesian Coordinates for $\mathbf{1}^{-}$(Energy : -948.3345493 hartrees):

\begin{tabular}{|c|c|c|c|}
\hline B & 1.51557100 & ๑. 02666200 & -0.00003600 \\
\hline $\mathrm{F}$ & 2.34364200 & $\odot .04123500$ & -1.14594800 \\
\hline $\mathrm{F}$ & 2.34378300 & $\odot .04128800$ & 1.14581200 \\
\hline $\mathrm{N}$ & $\odot .61854900$ & -1.23821100 & $\odot .0 \odot \odot \odot \odot \odot \odot \odot$ \\
\hline $\mathrm{N}$ & 0.57451600 & 1.25914800 & $\odot . \odot \odot \odot \odot 72 \odot \odot$ \\
\hline C & 1.03255400 & -2.52690900 & 0.00013300 \\
\hline C & $-\odot .0929460 \odot$ & -3.37087900 & $\odot .0 \odot \odot 370 \odot \odot$ \\
\hline $\mathrm{H}$ & -0.05806200 & -4.45054600 & ๑. 00058100 \\
\hline C & -1.22564400 & -2.55842400 & $\odot .0004840 \odot$ \\
\hline C & $-\odot .7790870 \odot$ & -1.22551400 & $\odot .0 \odot \odot 1020 \odot$ \\
\hline C & -1.51111700 & - ๑ . $0268480 \odot$ & - ๑. $0 \odot \odot \odot 170 \odot$ \\
\hline C & $-\odot .8217280 \odot$ & 1.19685300 & $-\odot . \odot \odot \odot \odot 75 \odot \odot$ \\
\hline C & -1.31539100 & 2.51305200 & $-\odot .0 \odot 01780 \odot$ \\
\hline C & -0.21223300 & 3.36520300 & $-0.0001190 \odot$ \\
\hline $\mathrm{H}$ & $-\odot .2156650 \odot$ & 4.44543100 & $-\odot .0002430 \odot$ \\
\hline C & 0.94254500 & 2.56174800 & $\odot .00003600$ \\
\hline C & 2.37117200 & 3. 00117400 & ๑.00005200 \\
\hline $\mathrm{H}$ & 2.89898500 & 2.61892300 & $\odot .87811400$ \\
\hline $\mathrm{H}$ & 2.89867100 & 2.61999800 & -0.87868400 \\
\hline $\mathrm{H}$ & 2.42641000 & 4. . 09168200 & $\odot .0 \odot \odot 6680 \odot$ \\
\hline C & 2.47574800 & -2.91590300 & 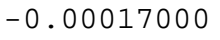 \\
\hline $\mathrm{H}$ & 2.98935600 & -2.51687400 & $-\odot .8792250 \odot$ \\
\hline $\mathrm{H}$ & 2.99020300 & $-2.5152990 \odot$ & $\odot .8776600 \odot$ \\
\hline $\mathrm{H}$ & 2.56891600 & -4.00381200 & $\odot . \odot \odot \odot 749 \odot \odot$ \\
\hline $\mathrm{H}$ & -2.26312600 & -2.85481400 & $\odot .00026600$ \\
\hline H & -2.36281800 & $2.7719940 \odot$ & $\odot .0 \odot \odot 122 \odot \odot$ \\
\hline C & $-3.0449280 \odot$ & $-\odot .05325700$ & $-\odot . \odot \odot \odot \odot 78 \odot \odot$ \\
\hline 0 & -3.55657100 & $-\odot .0608950 \odot$ & 1.13510500 \\
\hline 0 & -3.55626400 & $-\odot .062985 \odot \odot$ & -1.13539800 \\
\hline
\end{tabular}




\section{3. ${ }^{1} \mathrm{H}$-NMR, ${ }^{13} \mathrm{C}$-NMR and ${ }^{19}$ F-NMR Spectra}

${ }^{1} \mathrm{H}-\mathrm{NMR}$ Spectrum of 2-PFP in $\mathrm{CDCl}_{3}(400 \mathrm{MHz})$ :

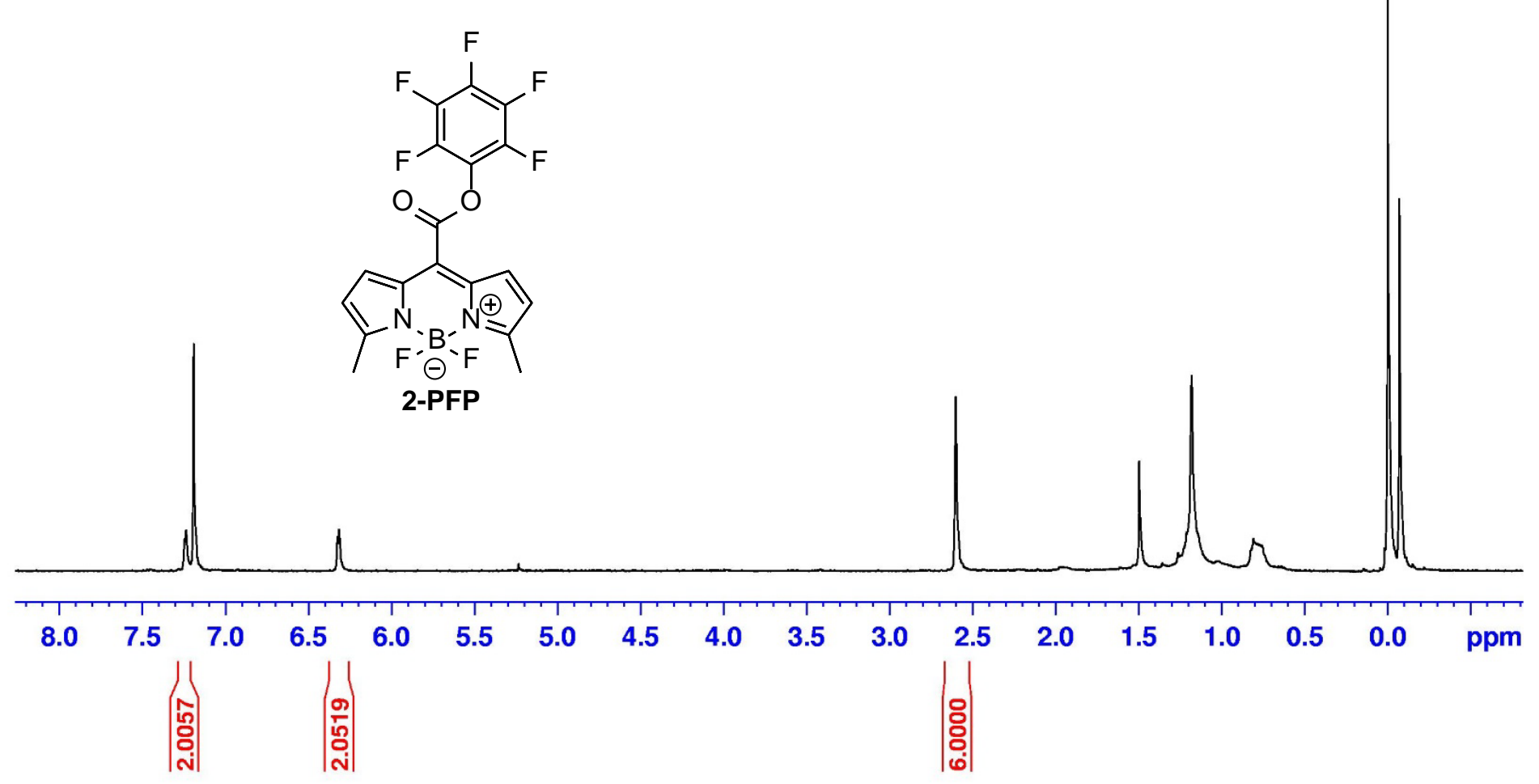

${ }^{13} \mathrm{C}$-NMR Spectrum of 2-PFP in $\mathrm{CDCl}_{3}(100 \mathrm{MHz})$ :

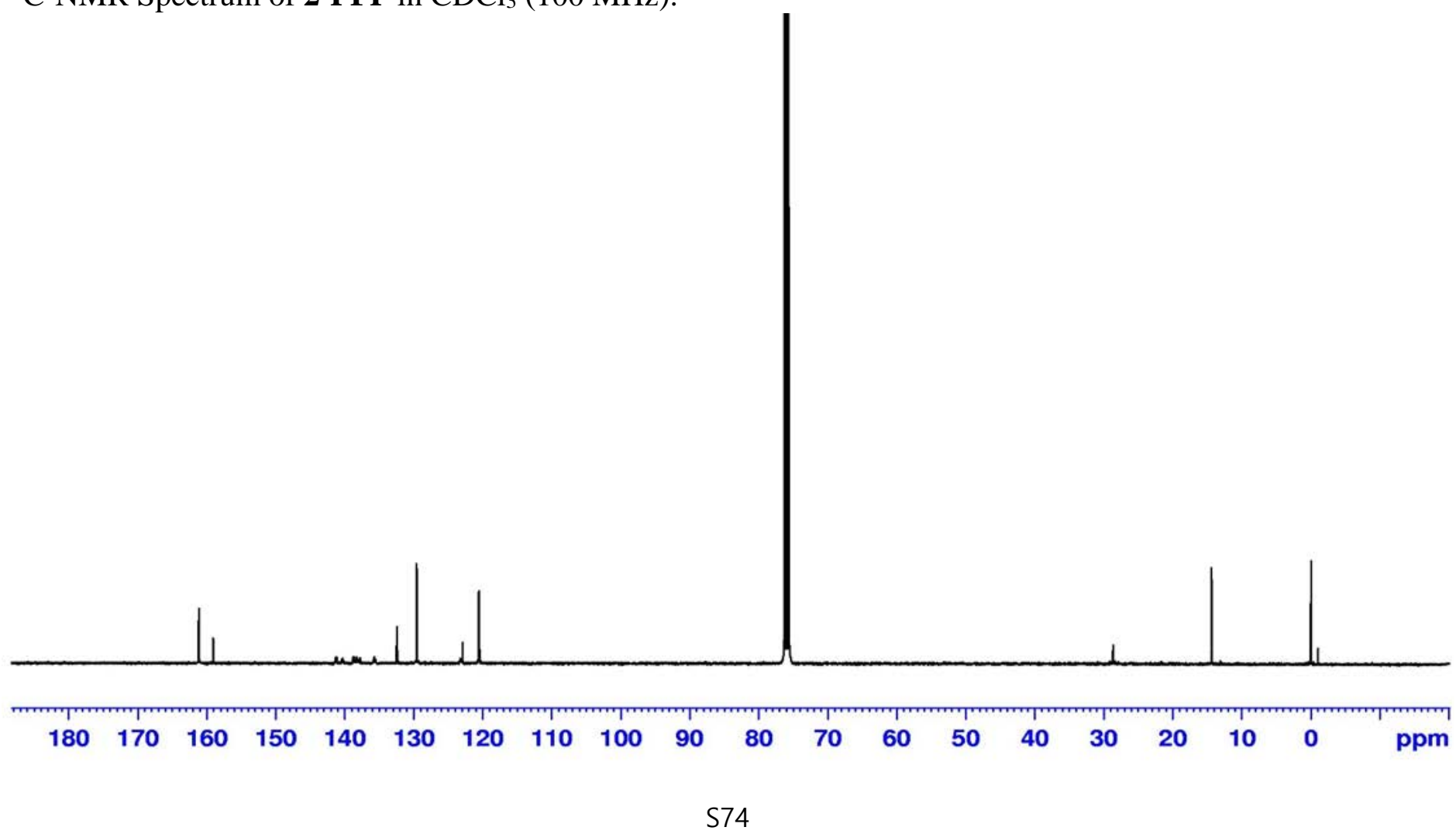


${ }^{19} \mathrm{~F}-\mathrm{NMR}$ Spectrum of 2-PFP in $\mathrm{CDCl}_{3}(470 \mathrm{MHz})$

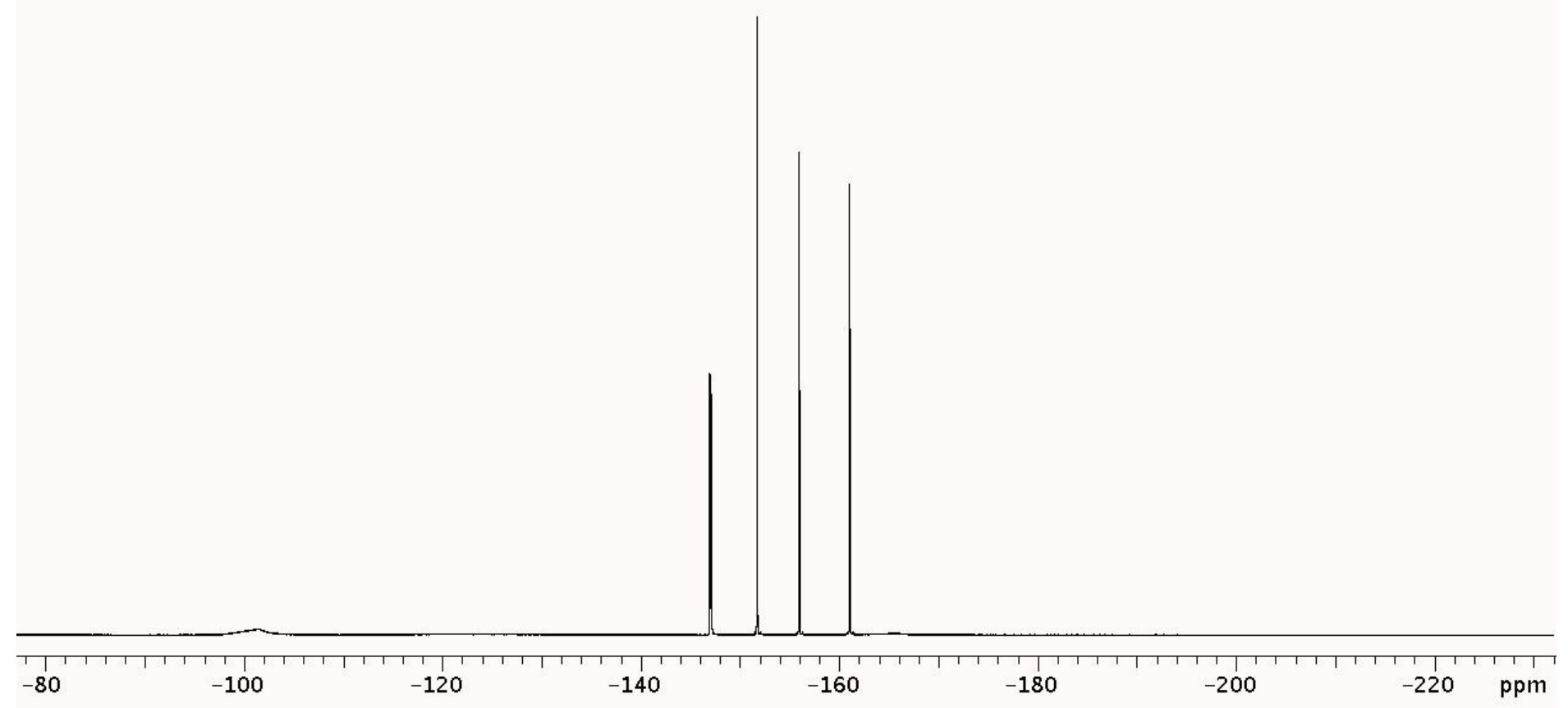


${ }^{1} \mathrm{H}-\mathrm{NMR}$ Spectrum of 2-NHS in $\mathrm{CDCl}_{3}(400 \mathrm{MHz})$ :
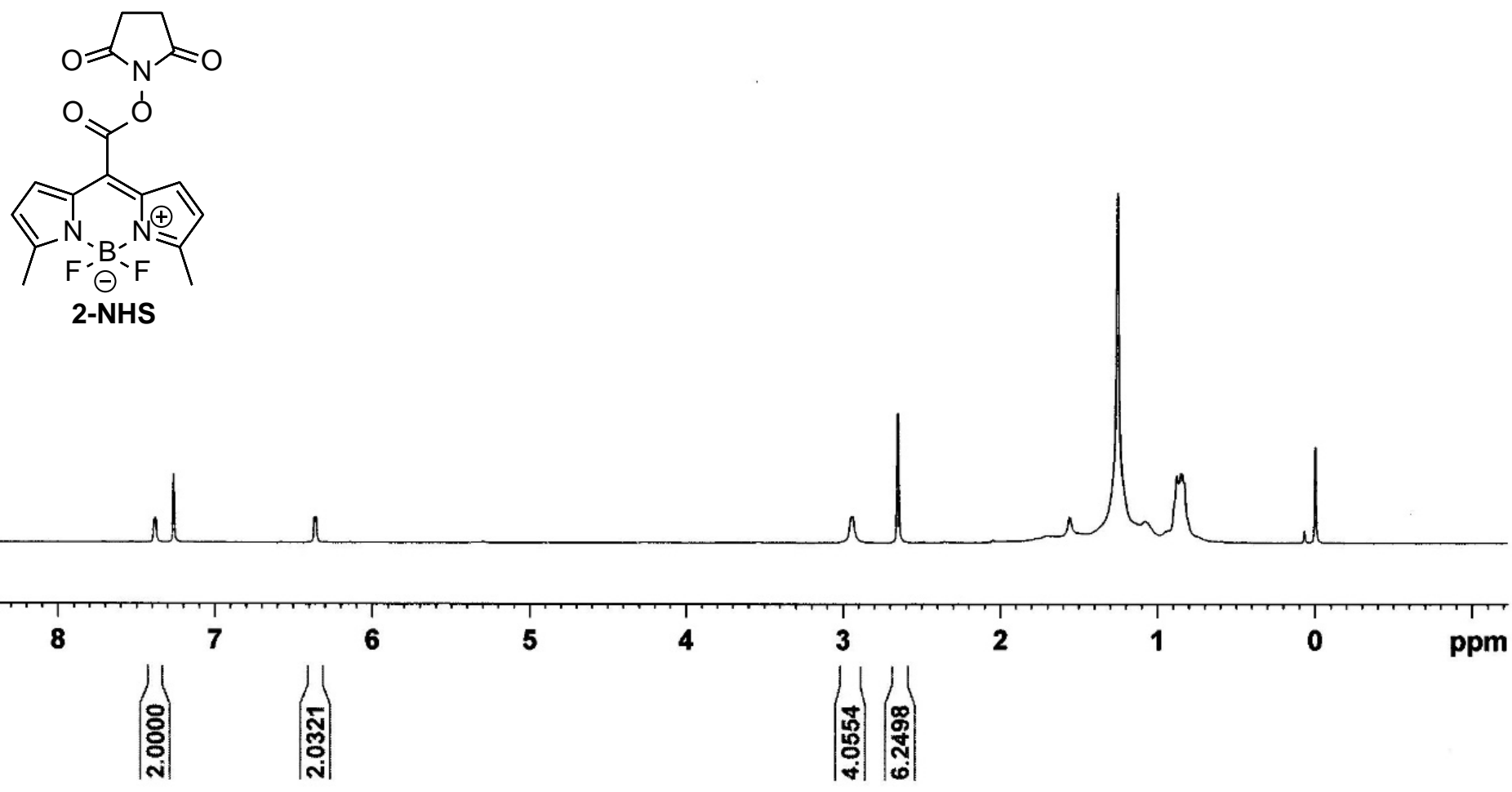

${ }^{13} \mathrm{C}-\mathrm{NMR}$ Spectrum of probe 2-NHS in $\mathrm{CDCl}_{3}(100 \mathrm{MHz})$ :

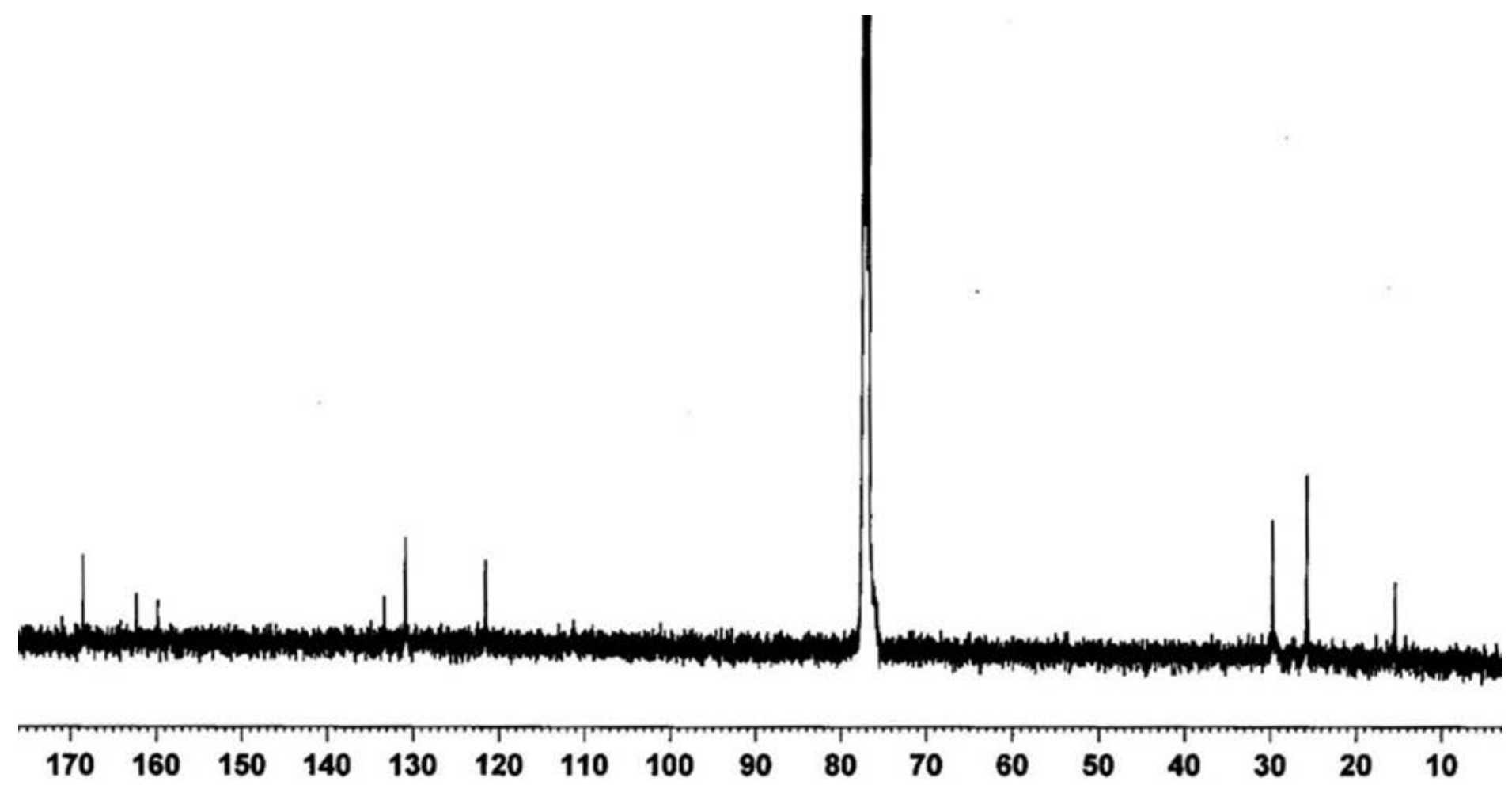


${ }^{1} \mathrm{H}-\mathrm{NMR}$ Spectrum of 3a in $\mathrm{CD}_{3} \mathrm{OD}(400 \mathrm{MHz})$ :

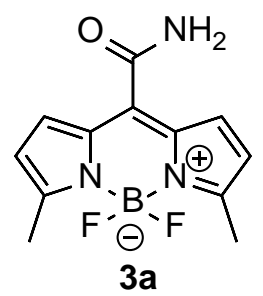

$3 a$

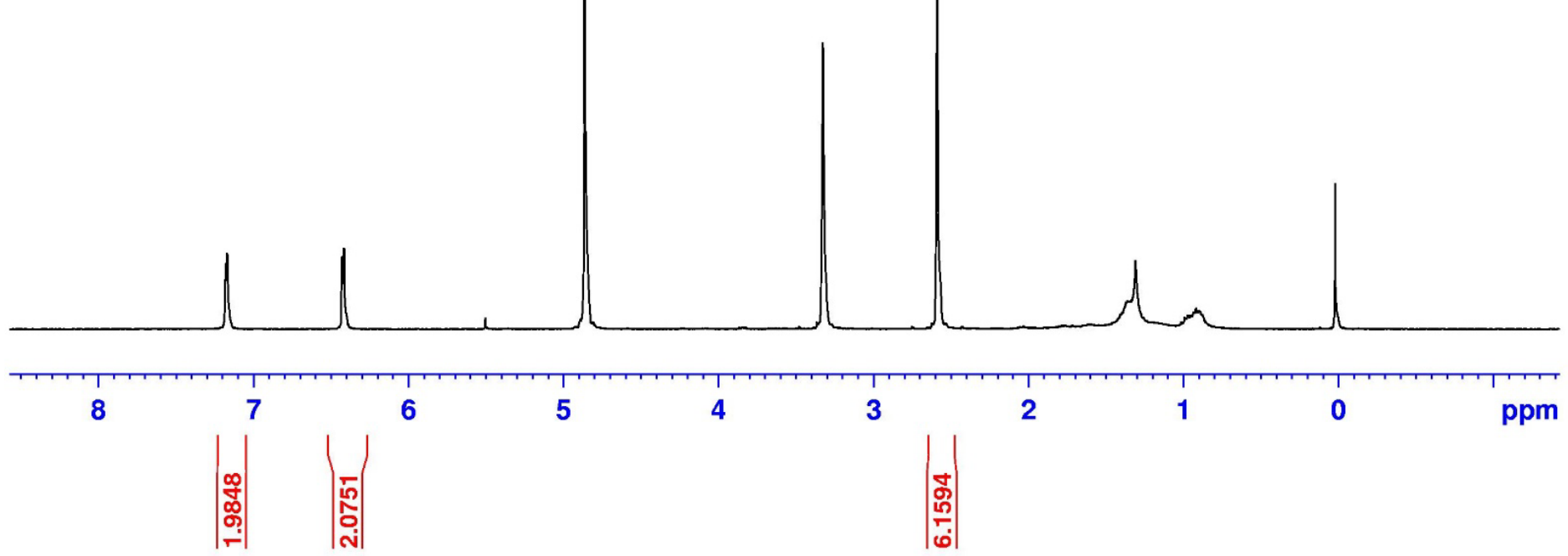

${ }^{13} \mathrm{C}$-NMR Spectrum of 3a in $\mathrm{CD}_{3} \mathrm{OD}(100 \mathrm{MHz})$ :

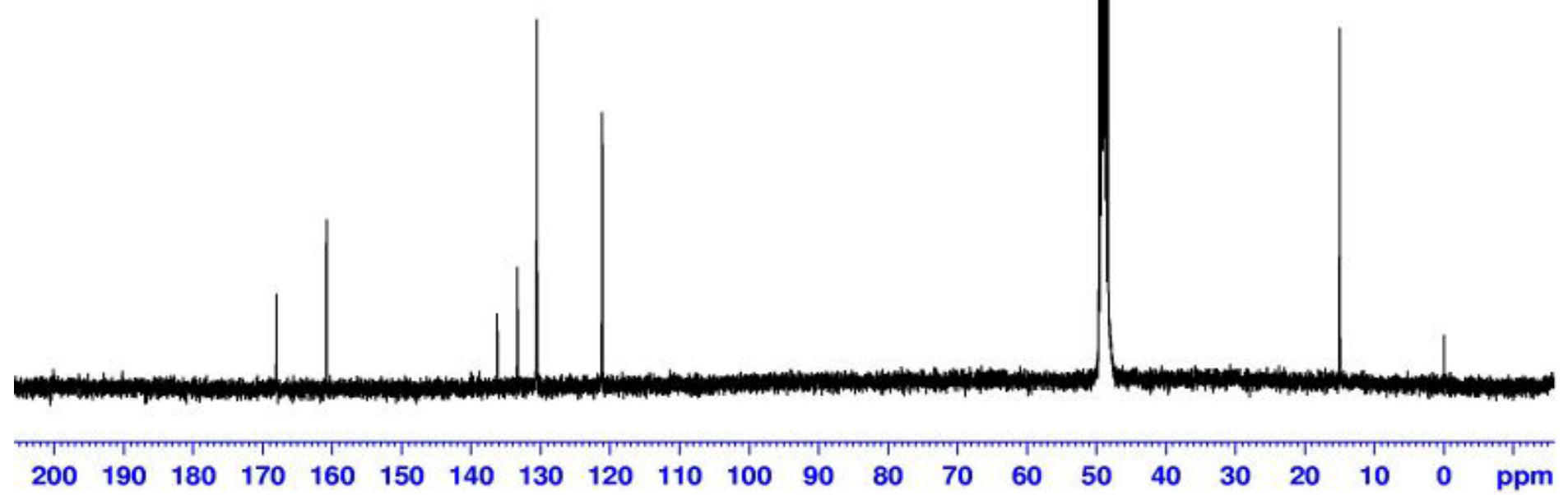


${ }^{1} \mathrm{H}-\mathrm{NMR}$ Spectrum of $\mathbf{3 b}$ in $\mathrm{CDCl}_{3}(400 \mathrm{MHz})$ :<smiles></smiles>

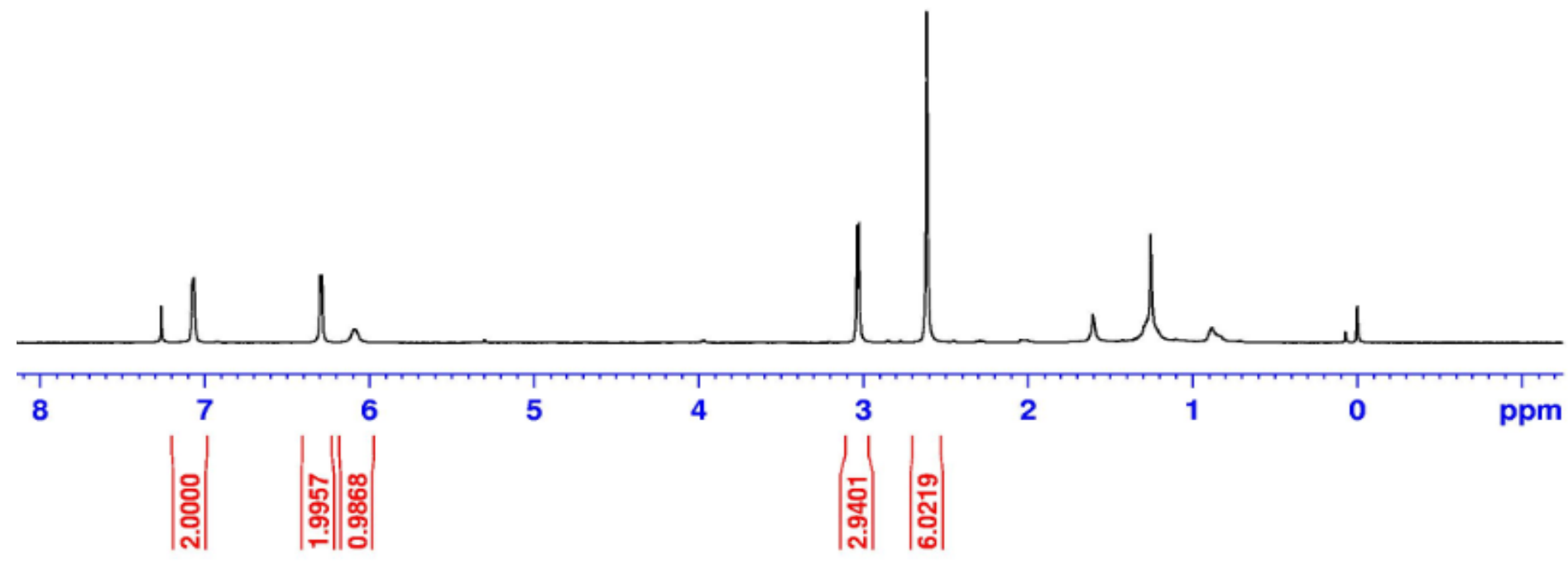

${ }^{13} \mathrm{C}-\mathrm{NMR}$ Spectrum of $\mathbf{3 b}$ in $\mathrm{CDCl}_{3}(100 \mathrm{MHz})$ :

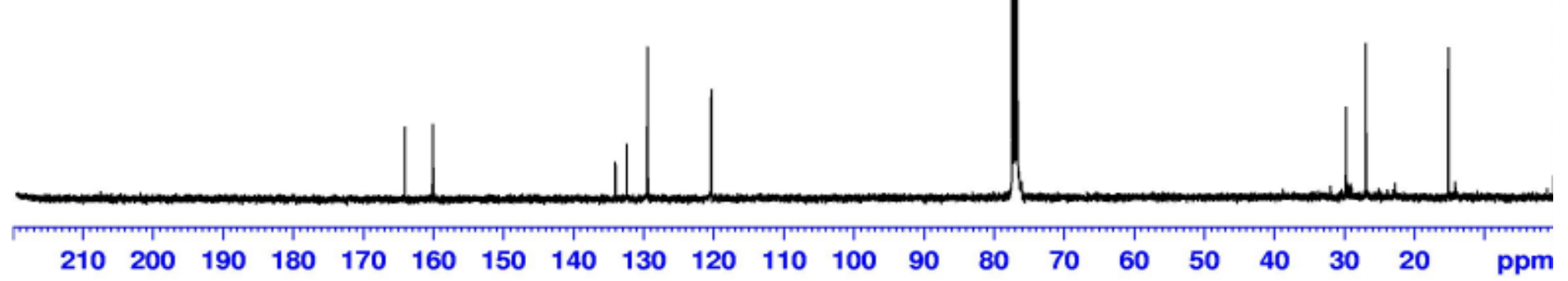


${ }^{1} \mathrm{H}-\mathrm{NMR}$ Spectrum of $3 \mathrm{c}$ in $\mathrm{CDCl}_{3}(400 \mathrm{MHz})$ :
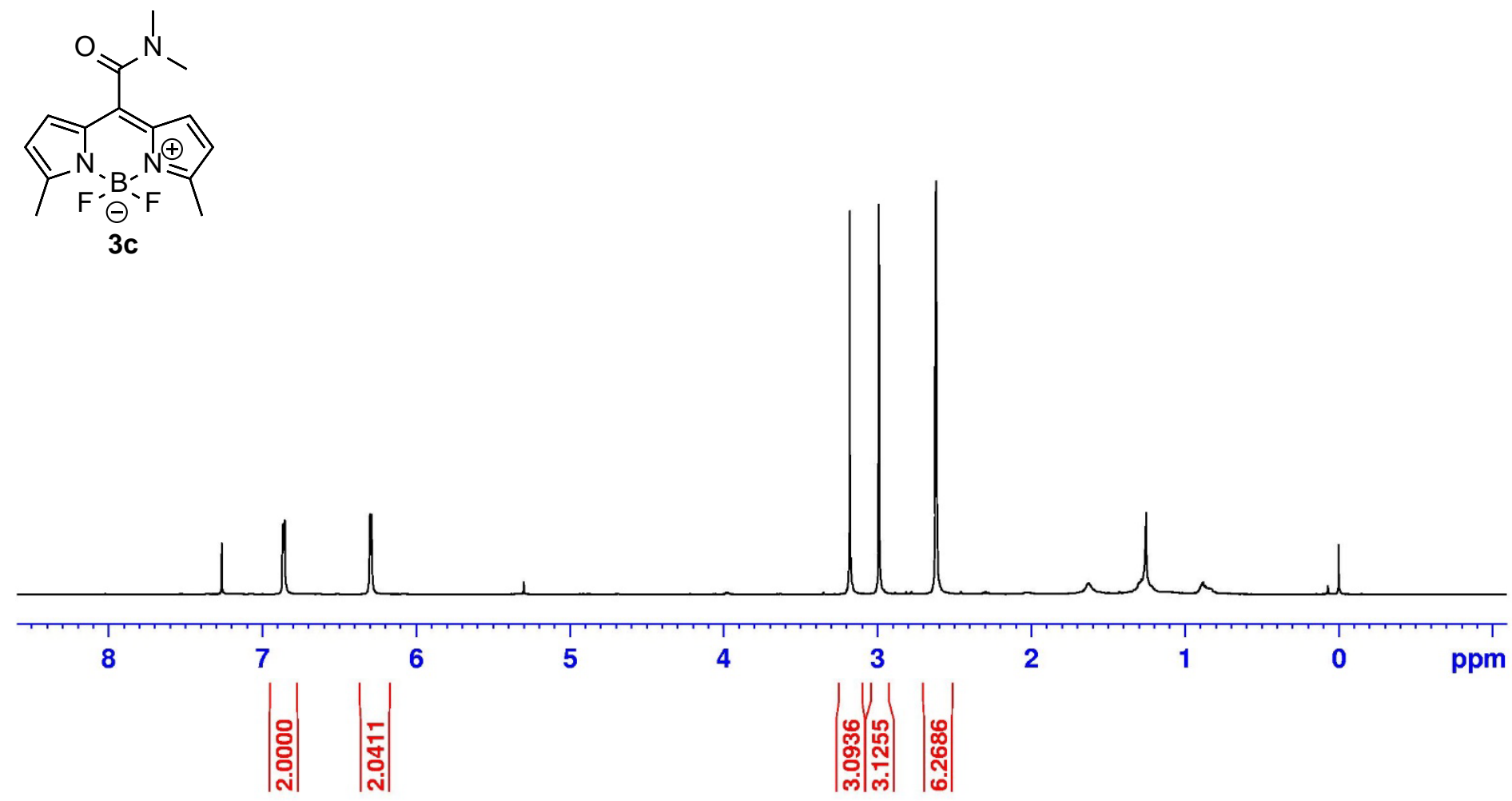

${ }^{13} \mathrm{C}-\mathrm{NMR}$ Spectrum of $3 \mathrm{c}$ in $\mathrm{CDCl}_{3}(100 \mathrm{MHz})$ :

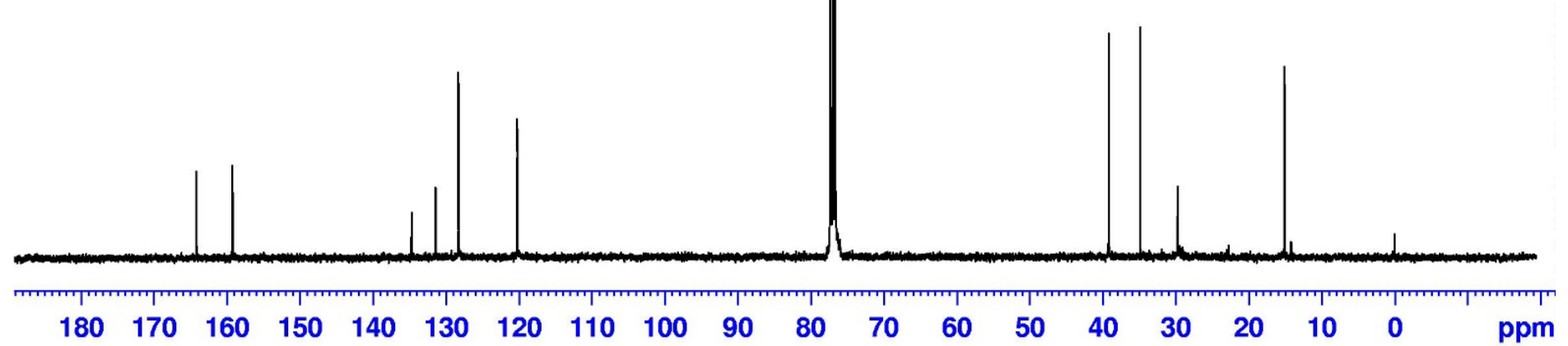


${ }^{1} \mathrm{H}-\mathrm{NMR}$ Spectrum of 3-Lyso in $\mathrm{CDCl}_{3}(400 \mathrm{MHz})$ :

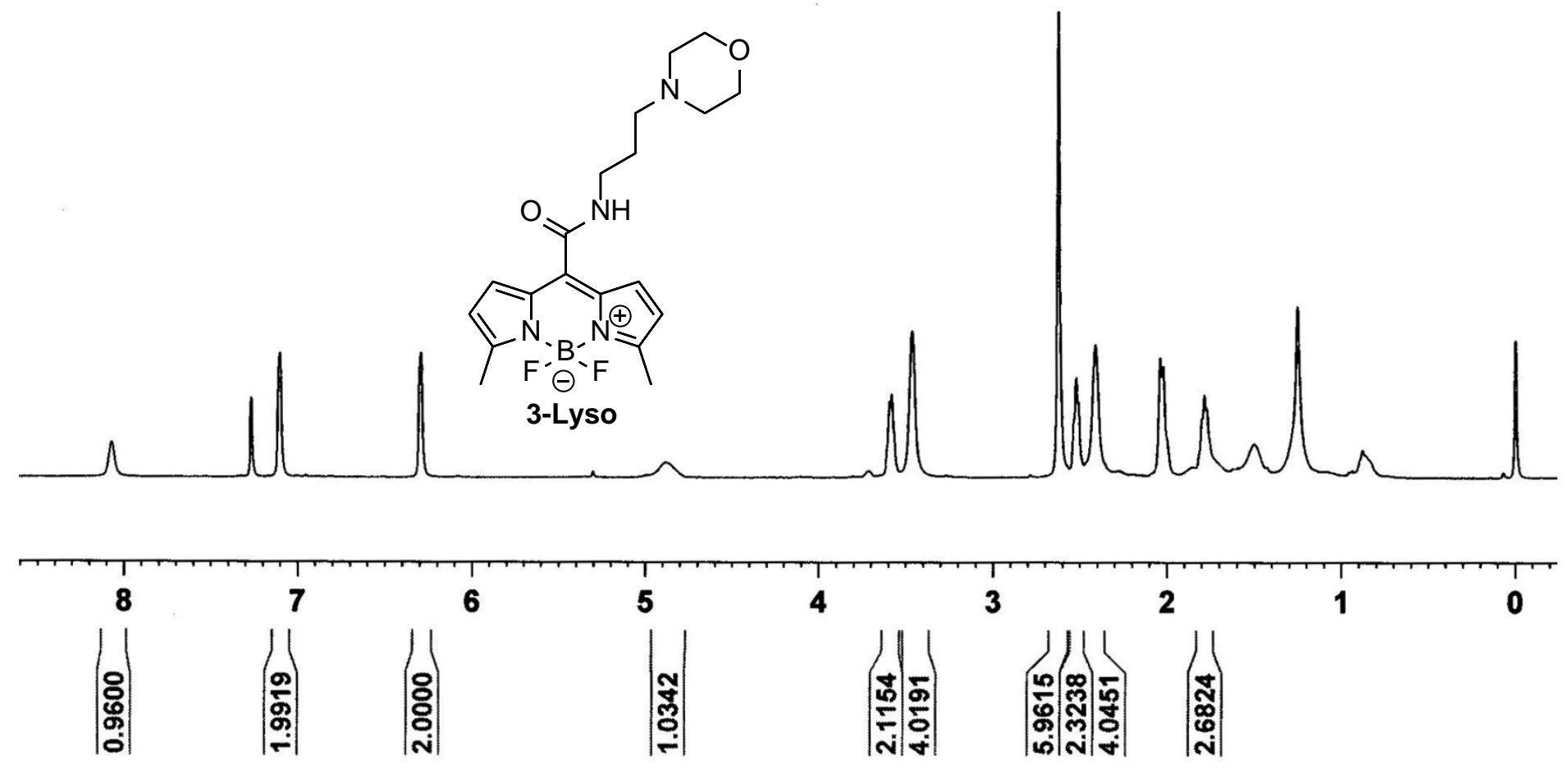

${ }^{13} \mathrm{C}-\mathrm{NMR}$ Spectrum of 3-Lyso in $\mathrm{CDCl}_{3}(100 \mathrm{MHz})$ :

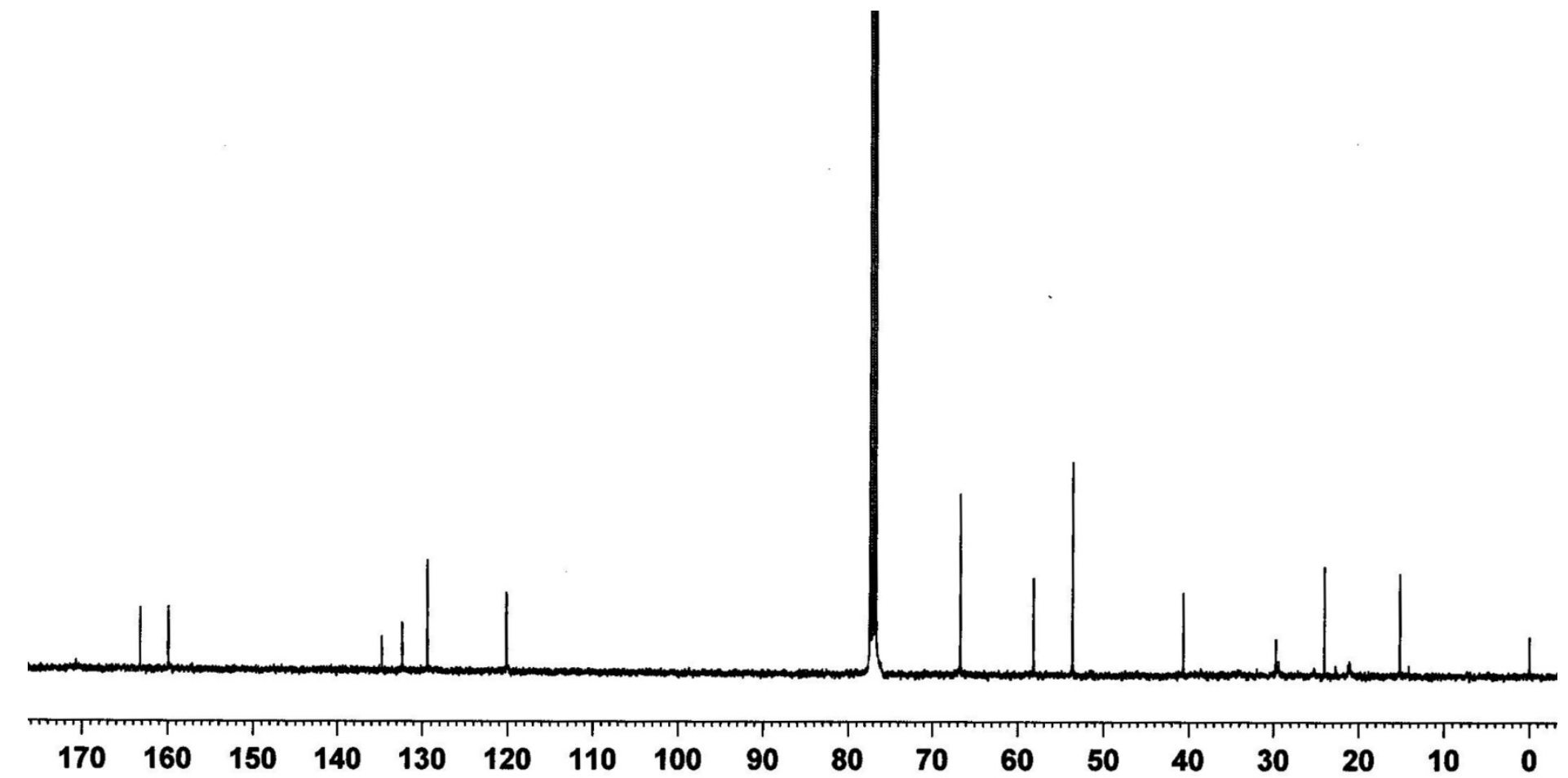


${ }^{1} \mathrm{H}-\mathrm{NMR}$ Spectrum of 3-Mito in $\mathrm{CD}_{3} \mathrm{OD}(400 \mathrm{MHz}$ ):
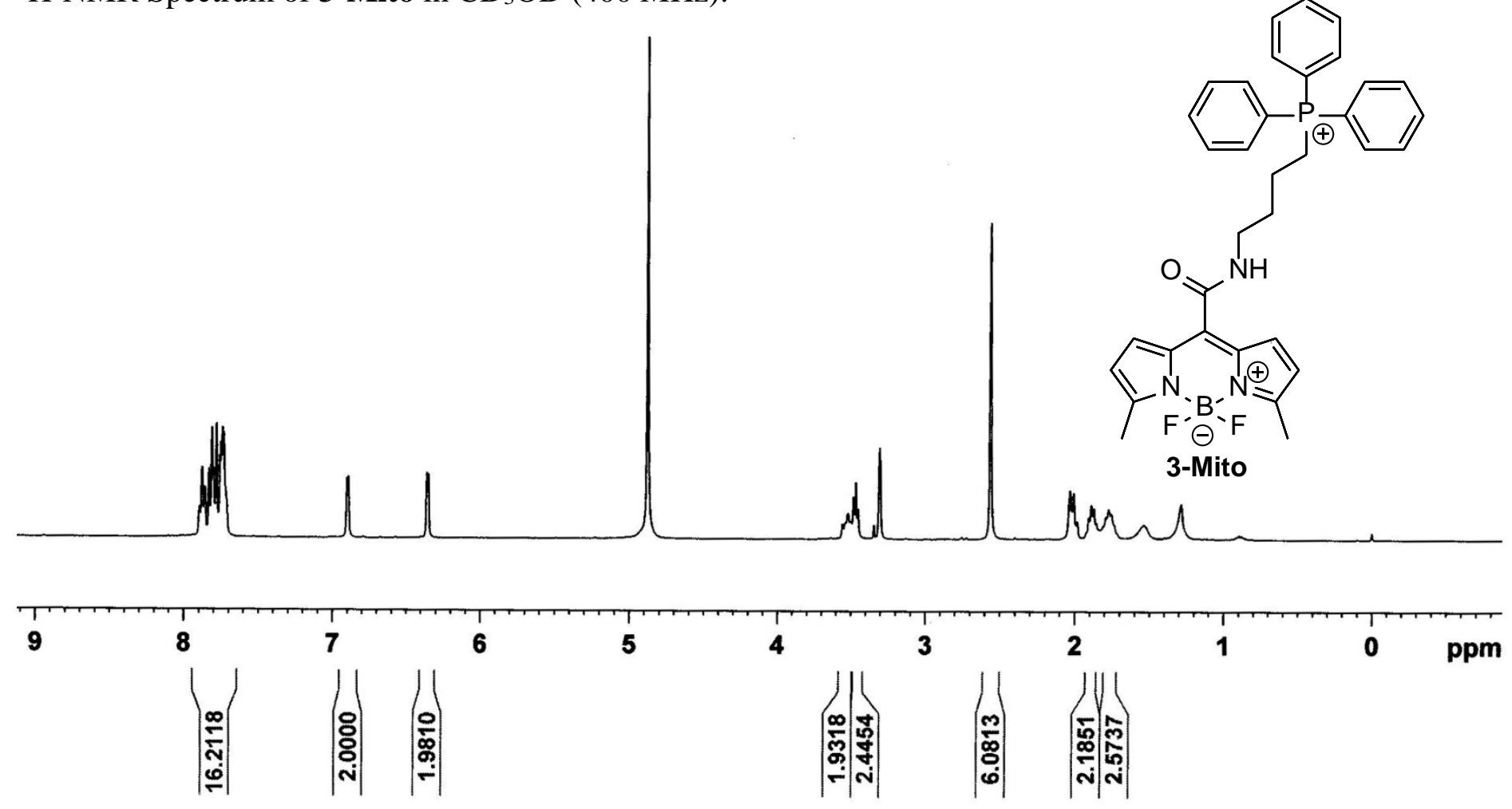

${ }^{13} \mathrm{C}-\mathrm{NMR}$ Spectrum of 3-Mito in $\mathrm{CD}_{3} \mathrm{OD}(100 \mathrm{MHz})$ :

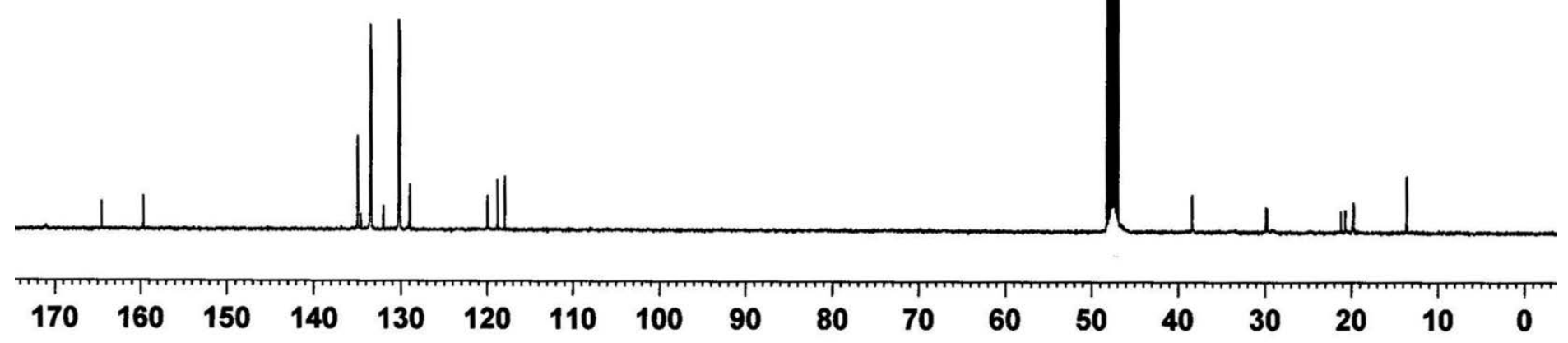


${ }^{1} \mathrm{H}-\mathrm{NMR}$ Spectrum of 3-ER in $\mathrm{CDCl}_{3}(400 \mathrm{MHz})$ :
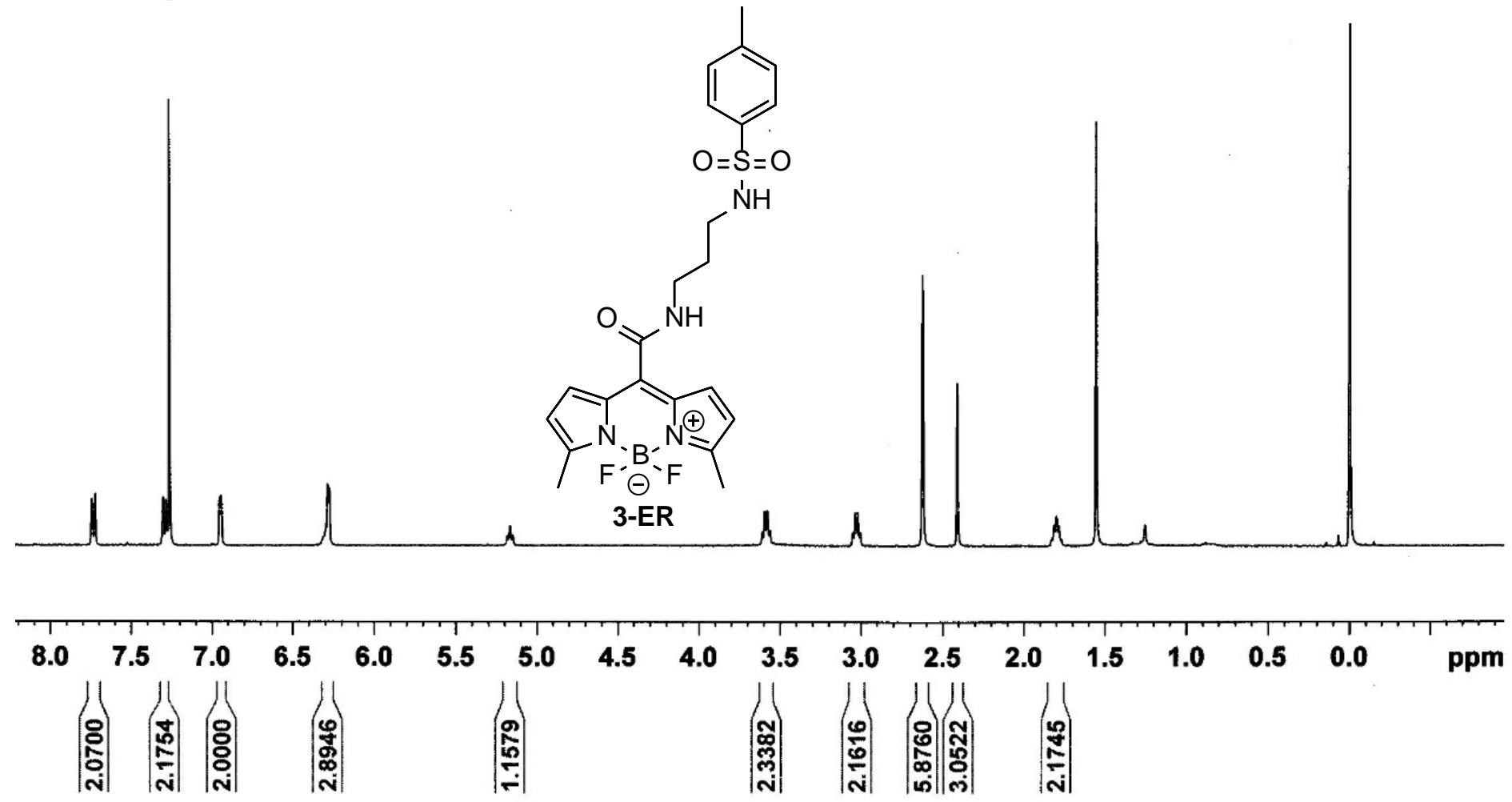

${ }^{13} \mathrm{C}-\mathrm{NMR}$ Spectrum of 3-ER in $\mathrm{CDCl}_{3}(100 \mathrm{MHz})$ :
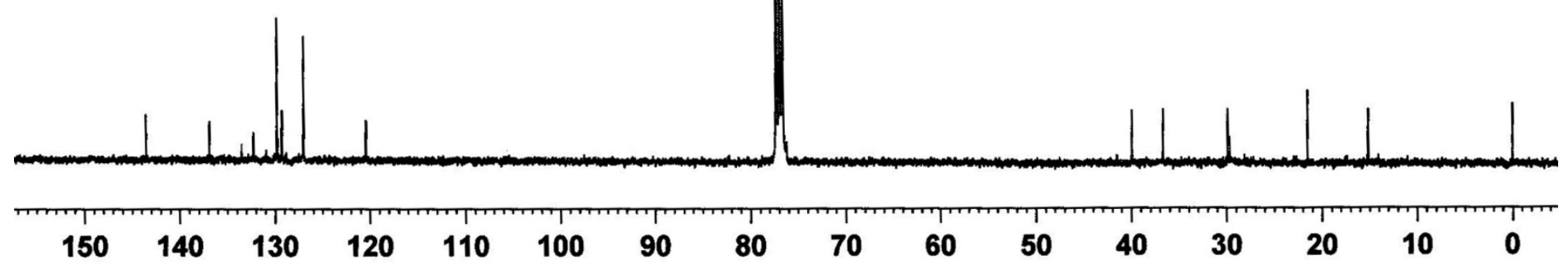


\section{References}

1. Kim, S.; Kim, H.; Choi, Y.; Kim, Y. A new strategy for fluorogenic esterase probes displaying low levels of non-specific hydrolysis. Chem. Eur. J. 2015, 21, 9645-9649.

2. Olsen, C. A.; Witt, M.; Jaroszewski, J. W.; Franzyk, H. Expedient protocol for solid-phase synthesis of secondary and tertiary amines. Org. Lett. 2004, 6, 1935-1938.

3. Chen, J.; Jiang, X.; Zhang, C.; MacKenzie, K. R.; Stossi, F.; Palzkill, T.; Wang, M. C.; Wang, J. Reversible Reaction-Based Fluorescent Probe for Real-Time Imaging of Glutathione Dynamics in Mitochondria. ACS Sens. 2017, 2, 1257-1261.

4. Abdel-Maksoud, M. S.; Kim, M.-R.; El-Gamal, M. I.; Gamal El-Din, M. M.; Tae, J.; Choi, H. S.; Lee, K.-T.; Yoo, K. H.; Oh, C.-H. Design, synthesis, in vitro antiproliferative evaluation, and kinase inhibitory effects of a new series of imidazo[2,1-b]thiazole derivatives. Eur. J. Med. Chem. 2015, 95, 453-463.

5. Brannon, J. H.; Madge, D. Absolute quantum yield determination by thermal blooming. Fluorescein. J. Phys. Chem. 1978, 82, 705-709.

6. Fischer, M.; Georges, J. Fluorescence quantum yield of rhodamine 6G in ethanol as a function of concentration using thermal lens spectrometry. Chem. Phys. Lett. 1996, 260, 115-118.

7. Shevchenko, A.; Tomas, H.; Havliš, J.; Olsen, J. V.; Mann, M. In-gel digestion for mass spectrometric characterization of proteins and proteomes. Nat Protoc. 2006, 1, 2856-2860.

8. Nesvizhskii, A. I.; Keller, A.; Kolker, E.; Abersold, R. A statistical model for identifying proteins by tandem mass spectrometry. Anal. Chem. 2003, 75, 4646-4658.

9. Mujumdar, R. B.; Ernst, L. A.; Mujumdar, S. R.; Lewis, C. J.; Waggoner, A. S. Cyanine dye labeling reagents: Sulfoindocyanine succinimidyl esters. Bioconjugate Chem. 1993, 4, 105-111.

10. Gill, S. C.; von Hippel, P. H. Calculation of protein extinction coefficients from amino acid sequence data. Anal. Biochem. 1989, 182, 319-326.

11. Park, M.; Shin, E.; Won, M.; Kim, J.-H.; Go, H.; Kim, H.-L.; Ko, J.-J.; Lee, K.; Bae, J. FOXL 2 Interacts with Steroidogenic Factor-1 (SF-1) and Represses SF-1-Induced CYP 17 Transcription in Granulosa Cells. Mol. Endocrinol. 2010, 24, 1024-1036.

12. Gaussian 09, Revision C.01, M. J. Frisch, G. W. Trucks, H. B. Schlegel, G. E. Scuseria, M. A. Robb, J. R. Cheeseman, G. Scalmani, V. Barone, B. Mennucci, G. A. Petersson, H. Nakatsuji, M. Caricato, X. Li, H. P. Hratchian, A. F. Izmaylov, J. Bloino, G. Zheng, J. L. Sonnenberg, M. Hada, M. Ehara, K. Toyota, R. Fukuda, J. Hasegawa, M. Ishida, T. Nakajima, Y. Honda, O. Kitao, H. Nakai, T. Vreven, J. A. Montgomery, Jr., J. E. Peralta, F. Ogliaro, M. Bearpark, J. J. Heyd, E. Brothers, K. N. Kudin, V. N. Staroverov, T. Keith, R. Kobayashi, J. Normand, K. Raghavachari, A. Rendell, J. C. Burant, S. S. Iyengar, J. Tomasi, M. Cossi, N. Rega, J. M. Millam, M. Klene, J. E. Knox, J. B. Cross, V. Bakken, C. Adamo, J. Jaramillo, R. Gomperts, R. E. Stratmann, O. Yazyev, A. J. Austin, R. Cammi, C. Pomelli, J. W. Ochterski, R. L. Martin, K. Morokuma, V. G. Zakrzewski, G. A. Voth, P. Salvador, J. J. Dannenberg, S. Dapprich, A. D. Daniels, O. Farkas, J. B. Foresman, J. V. Ortiz, J. Cioslowski, and D. J. Fox, Gaussian, Inc., Wallingford CT, 2010.

13. Kim, S.; Bouffard, J.; Kim, Y. Tailoring the Solid-State Fluorescence Emission of BODIPY Dyes by meso Substitution. Chem. Eur. J. 2015, 21, 17459-17465. 